\title{
Geographical Origins and Economic Consequences of Language Structures*
}

\author{
Oded Galor
}

February 4, 2017

\begin{abstract}
This research explores the economic causes and consequences of language structures. It advances the hypothesis and establishes empirically that variations in pre-industrial geographical characteristics that were conducive to higher returns to agricultural investment, gender gaps in agricultural productivity, and the emergence of hierarchical societies, are at the root of existing cross-language variations in the structure of the future tense and the presence of grammatical gender and politeness distinctions. Moreover, the research suggests that while language structures have largely reflected past human experience and ancestral cultural traits, they have independently affected human behavior and economic outcomes.

Keywords: Comparative Development, Cultural Evolution, Language Structure, Future Tense, Politeness Distinctions, Grammatical Gender, Human Capital, Education
\end{abstract}

JEL Classification: D01, D03, J16, Z10, Z13

${ }^{*}$ The authors are grateful to Joan Bybee, Justin Cook, Delia Furtado, Paola Giuliano, Luigi Guiso, Klaus Desmet, Stelios Michalopoulos, and David Weil, as well as conference participants at the "Annual Meetings of the American Economic Association", 2016; "Deep Rooted Factors in Comparative Development", 2016, Zeuthen Lectures, Copenhagen, 2016, and seminar participants at Ben-Gurion, Brown, Clark, Haifa, Southern Methodist, Tel-Aviv, and UC - Merced, for useful comments and discussions.

${ }^{\dagger}$ Department of Economics, Brown University; NBER, CEPR, IZA, CES-Ifo. E-mail: Oded_Galor@brown.edu

${ }^{\ddagger}$ Department of Economics, Southern Methodist University. E-mail: ozak@smu.edu

${ }^{\S}$ Department of Economics, University of Haifa. Email: asarid@econ.haifa.ac.il 


\section{Introduction}

The origins of the vast inequality in the wealth of nations have recently been attributed to the persistent effect of an uneven distribution of pre-industrial geographical, cultural, institutional and human characteristics across the globe. ${ }^{1}$ In particular, evidence suggests that regional variations in the geographical environment in the distant past have contributed to the differential formation of cultural traits and their lasting effect on comparative economic development across countries, regions and ethnic groups. ${ }^{2}$ In light of the coevolution of cultural and linguistic characteristics in the course of human history, the evolution of language has conceivably reinforced the persistent effect of cultural factors on the process of development. ${ }^{3}$ Nevertheless, the significance of these evolutionary processes, and their potential common geographical roots, for the understanding of the process of development and the unequal distribution of wealth across nations has remained obscured.

This research explores some of the most fundamental and intriguing mysteries about the origins of the coevolution of linguistic and cultural traits and their impact on the development process: ${ }^{4}$ Has the coevolution of linguistic and cultural traits contributed to the persistence of cultural characteristics and their lasting effect on economic prosperity? Have language structures merely reflected existing cultural traits or have they influenced human behavior and values and contributed directly to the development process? What are the geographical roots of the coevolution of linguistic and cultural traits? Are the geographical characteristics that triggered the coevolution of culture and language critical for the understanding of the contribution of cultural and linguistic characteristics for the wealth of nations?

The analysis uncovers geographical origins of the coevolution of cultural and linguistic characteristics in the course of human history and their significance for the understanding of the unequal distribution of wealth across the globe. It advances the hypothesis and establishes empirically that pre-industrial geographical characteristics, which were conducive to the emergence and progression of complementary cultural traits, triggered an evolutionary process in language structures that has fostered the transmission of these cultural traits and has magnified their impact on the process of development.

The research establishes that regional variations in pre-industrial geographical characteristics that were conducive to higher return to agricultural investment, and thus to the emergence of long-term orientation, are at the root of existing cross-language variations in the structure of the future tense. Moreover, the study uncovers the effect of geographical characteristics on two additional language structures: grammatical gender and politeness distinctions. First, it suggests that differences in the suitability of land for the adoption of agricultural technology, and its differential effect on agricultural productivity across genders, have contributed to the presence of cross-language variations in gram-

\footnotetext{
${ }^{1}$ Gallup et al. (1999), Guiso et al. (2004, 2006), Tabellini (2010), Acemoglu et al. (2001), Glaeser et al. (2004), and Ashraf and Galor (2013b).

${ }^{2}$ Alesina et al. (2013) and Galor and Özak (2016).

${ }^{3}$ Cavalli-Sforza et al. (1994), Cavalli-Sforza (2000), and Richerson et al. (2010).

${ }^{4}$ Existing economic research predominantly views languages as an identifier of cultural and ethnic groups. Linguistic fractionalization as well as linguistic distance have been extensively used as a proxy for ethnic fractionalization and cultural distance in the exploration of the effect ethnic diversity on economic growth and the impact of cultural distance on the diffusion of development (Easterly and Levine, 1997; Fearon, 2003; Alesina et al., 2003; Alesina and Ferrara, 2005; Desmet et al., 2012; Harutyunyan and Özak, 2016).
} 
matical gender. Second, it indicates that regional variations in the diversity of soil quality that have contributed to specialization, trade and the emergence of hierarchical structures, are at the origin of existing variations in the presence of politeness distinctions across languages.

The research further suggests that while language structures have been largely a reflection of past human experience, and in particular ancestral cultural traits, they have played a pivotal role in the persistent effect of cultural characteristics on comparative economic development. Moreover, the evidence suggests that there exists a direct and independent effect of language structures on human behavior and contemporary economic outcomes.

The hypothesized coevolution of culture and language structures generates several predictions and novel insights. First, in light of the communication function of language, emerging language structures have conceivably facilitated efficient communication across individuals, while enhancing the transmission of cultural values. The forces of natural selection across language structures may have therefore generated an evolutionary advantage to those structures that reflected dominating cultural traits. Hence, the geographical environment and the corresponding economic incentives that have governed the evolution of cultural traits may have also triggered the evolution of complementary language structures. In particular, regional differences in geographical characteristics that have contributed to the emergence of variations in cultural traits may have also contributed to cross-language variations of complementary language structures.

Second, in view of the pivotal role of language in the transmission of knowledge and values, language structures have plausibly affected the diffusion of cultural values and thus human behavior across members of society, reinforcing existing cultural traits and their intergenerational transmission. Moreover, it is not inconceivable that language structures per se may have directly influenced individuals' mindsets and thus human behavior, beyond the non-linguistic transmission channel of culture. ${ }^{5}$

Third, considering the pivotal role of language as a coordination device across members of society, the evolution of language structures necessitated and reflected the adoption of linguistic mutations by society as a whole. Unlike the feasibility of a unilateral deviation by individuals from existing cultural norms, the diffusion of unilateral linguistic innovations is unlikely and language structures would therefore tend to be more persistent than cultural traits. Thus, inevitably, cultural traits reflected in language structures would be expected to be more persistent across time and space.

The proposed hypothesis about the interaction between the geographical environment and the coevolution of cultural and linguistic traits is exemplified in three distinct settings. Consider a hierarchical society characterized by obedience, conformity, and power distance. Conceivably, language structures that reinforced the existing hierarchical structure and cultural norms were likely to emerge and persist in this unequal society. In particular, politeness distinctions in pronouns (e.g., "tu" and "usted" in Spanish, "Du" and "Sie" in German, and "tu" and "vous" in French) were likely to appear and endure in hierarchical societies. ${ }^{6}$ Thus, geographical characteristics, such as ecological diversity

\footnotetext{
${ }^{5}$ The Oxford English Dictionary defines mindset as "[a]n established set of attitudes, esp. regarded as typical of a particular group's social or cultural values; the outlook, philosophy, or values of a person;"... "an incident of a person's Weltanschauung or philosophy of life".

${ }^{6}$ Politeness distinctions could have emerged in order to mitigate the coordination cost in the interaction between individuals from various social strata (Brown and Levinson, 1987; Brown and Gilman, 1989; Helmbrecht, 2003, 2005).
} 
that were conducive to the development of hierarchical societies (Fenske, 2014; Litina, 2014; DepetrisChauvin and Özak, 2016), would be expected to be associated with the emergence of politeness distinctions as well.

Similarly, in a society characterized by distinct gender roles and consequently by the existence of gender bias, grammatical gender that could have fortified the existing social structure and cultural norms may have emerged and persisted over time. Thus, geographical characteristics that were complementary to the usage of the plow and thus to the emergence of distinct gender roles in society (Pryor, 1985; Alesina et al., 2013), may have fostered the emergence and the prevalence of sex-based grammatical gender.

Finally, in societies characterized by long-term orientation, a structure of the future tense that could have reinforced the efficiency of future oriented behavior may have emerged and persisted over time. Hence, pre-industrial agro-climatic characteristics that were conducive to higher return to agricultural investment and therefore to the prevalence of long-term orientation (Galor and Özak, 2016) may have fostered the emergence and the prevalence a long-term oriented future tense.

The proposed hypothesis is tested in two stages. In the initial stage, the empirical analysis explores the origins of language structures, focusing on the geographical roots of the structure of the future tense, and the presence of sex-based grammatical gender systems and politeness distinctions in pronouns. In particular, the analysis accounts for a large set of confounding geographical characteristics and regional fixed-effects, mitigating concerns about the role of omitted geographical, institutional, cultural, or human characteristics in the estimated effect of the geographical origins of language structures. $^{7}$

The empirical analysis examines initially whether agro-climatic characteristics, that have governed the return to agricultural investment and are thus associated with long-term orientation (Galor and Özak, 2016), have influenced the structure of the future tense. Consistent with the view that periphrastic future tense reflects intentional future-orientated behavior (as elaborated in section 2.1), the analysis establishes that higher potential crop return is significantly associated with the presence of periphrastic future tense in a language. Moreover, lending credence to the proposed hypothesis, the pattern of subsistence among the speakers of a language (i.e., their intensive use of agricultural) appears to be the mediating channel through which crop return, and thus long-term orientation, have affected the presence of periphrastic future tense. Furthermore, crop return is not associated with other language structures (e.g., the presence of a past or perfect tense, grammatical gender, possessive), suggesting that periphrastic future tense is reflecting primarily long-term orientation.

The empirical analysis further explores the impact of potential crop return within the ancestral homeland of contemporary language families on the presence of periphrastic future tense in individual daughter languages. In light of the observation that contemporary languages within a language family descended from a common proto-language (Bouckaert et al., 2012; Pagel et al., 2013), the hypothesis further suggests that crop return in the ancestral homeland of the proto-language might have had a persistent effect on the presence of periphrastic future tense in its daughter languages. Consistent with this prediction, the analysis establishes that the share of daughter languages within a language

\footnotetext{
${ }^{7}$ The results are unaffected by spatial auto-correlation and selection on unobservables.
} 
family in which periphrastic future tense is present is positively associated with crop return in the ancestral homeland of the proto-language.

The empirical analysis addresses potential concerns regarding reverse causality, omitted variables and sorting: (i) It uses potential crop return (associated with agro-climatic conditions that are orthogonal to human intervention) to overcome potential concerns about reverse causality that may be associated with the effect of long-term orientation on cultivation methods, the choice of technologies, and actual crop returns. (ii) It focuses on languages located outside the ancestral homeland of their proto-language, while accounting for regional fixed-effects, to address potential concerns regarding omitted variables at the host-region level, mirroring the epidemiological approach to cultural diffusion. (iii) It exploits the descent of contemporary languages from proto-languages to establish the persistent effect of geographical characteristics in the proto-language homeland, rather than sorting in the course of a demic diffusion, on the evolution of periphrastic future tense.

Similarly, the study subsequently uncovers the effect of geographical characteristics on two additional language structures: grammatical gender and politeness distinctions. The analysis establishes that geographical characteristics that have contributed to variations in agricultural productivity across genders are associated with the prevalence of grammatical gender, while geographical characteristics that have contributed to ecological diversity and the emergence of hierarchical societies are associated with the prevalence of politeness distinctions. Interestingly, while the geographical characteristics of the ancestral homeland of their proto-language have a persistent effect on both the existence of the periphrastic future tense and of sex-based grammatical gender systems, it is the geographical characteristics of the daughter languages' homeland that affect the existence of politeness distinctions, consistent with evidence about the greater adaptability of this language structure to environmental changes.

In its second stage, the empirical analysis examines the effects of language structures on contemporary economic outcomes, conceivably via their potential impact on the persistence of ancestral cultural traits as well as on individual behavior. Several strategies are employed in order to surmount the significant hurdles in the identification of the effect of language-embodied cultural traits on human behavior, while isolating this effect from the persistent effect of cultural traits via non-linguistic channels. Following the epidemiological approach for the identification of the persistent effects of cultural traits on human behavior and economic outcomes (Giuliano, 2007; Fernandez and Fogli, 2009), the research focuses on the behavior of second-generation migrants who share the same country of birth, removing concerns about the role of geographical, institutional and cultural characteristics in this country.

Nevertheless, the traditional epidemiological approach cannot fully distinguish between the persistent effect of observed cultural characteristics and omitted ancestral characteristics at the parental countries of origin. In particular, since the basic premise of the epidemiological approach is that second-generation migrants from the same parental countries of origin share the cultural heritage of those countries, the traditional epidemiological approach cannot account for parental countries of origin fixed-effects. In contrast, in light of the fact that second-generation migrants that have identical parental countries of origin may speak different languages, one can isolate the effect of language- 
embodied cultural traits on human behavior, by accounting for parental countries of origin fixedeffects (i.e., common ancestral factors such as geographical, institutional and cultural characteristics that may affect individual behavior). Hence, the analysis exploits variations in language structures across individuals that are originated from the same ancestral homelands in order to identify the effect of language-embodied cultural traits on human behavior.

The analysis focuses on the effect of (i) the presence periphrastic future tense and its association with long-term orientation on educational attainment, and (ii) the presence of sex-based grammatical gender and its association with gender bias on female educational attainment. The analysis establishes a beneficial effect of speaking a language with periphrastic future tense (associated with long-term orientation) on college attendance and an adverse effect of speaking a language with sex-based grammatical gender (associated with gender-bias) on female college attendance.

This research is the first attempt in the economic literature to explore the geographical origins of language structures and to advance the hypothesis that regional variations in geographical characteristics have contributed to cross-language variations in language structures such as the structure of the future tense and the presence of grammatical gender and politeness distinctions. ${ }^{8}$ Furthermore, the empirical methodology advanced in the course of this research augments the epidemiological approach and advances a methodology that permits the isolation the effect of cultural traits that are languageembodied on human behavior from the persistent effects of culture via non-linguistic channels. This advancement overcomes some of the limitations of the existing studies about the association between language structures and economic outcomes (Chen, 2013; Roberts et al., 2015).

Moreover, the analysis sheds additional light on the geographical and bio-cultural origins of comparative development (Diamond, 1997; Ashraf and Galor, 2013b), the interaction between the evolution of human traits and the process of development (Galor and Moav, 2002; Spolaore and Wacziarg, 2013), and the persistence of cultural characteristics (Bisin and Verdier, 2000; Nunn and Wantchekon, 2011; Fernández, 2012; Alesina et al., 2013; Galor and Özak, 2016).

\section{Data}

This section presents the data used in the empirical analysis of the origins of language structures. In particular, it introduces the data on the structure of the future tense and the presence of sex-based grammatical gender and politeness distinctions in nouns, as well as measures of their hypothesized geographical determinants.

\subsection{Main Variables of Interest: Language Structures}

This subsection introduces the main variables of interest in the analysis, namely the existence of a periphrastic future tense, sex-based grammatical gender systems and politeness distinctions in pronouns across languages, based on The World Atlas of Language Structures - WALS - (Dryer, 2013), which

\footnotetext{
${ }^{8}$ In contrast, Michalopoulos (2012) and Ashraf and Galor (2013a) explore the geographical attributes (diversity of soil quality and migratory distance from Africa) that contributed to variation in the number of languages within a geographical region.
} 
is the most comprehensive database of language structures gathered from descriptive materials by 55 authors.

The analysis encodes the existence of a language structure $S$ in language $\ell, S_{\ell}$, as follows:

$$
S_{\ell}= \begin{cases}1 & \text { if the structure exists in language } \ell \\ 0 & \text { if the structure does not exist in language } \ell\end{cases}
$$

In order to link linguistic characteristics of a language to the history and geography of the people that speak that language, the analysis creates a correspondence table that links the languages in WALS to other datasets. In particular, the analysis merges the linguistic data from WALS with the Ethnologue (Lewis et al., 2009) in order to identify the geographical regions where languages are spoken today. This allows the assignment of geographical characteristics of the linguistic homeland to each language, where the linguistic homeland of a language is the indigenous region where the language is spoken today. ${ }^{9}$ Additionally, the research links these two datasets to the Ethnographic Atlas (Murdock, 1967) and the Standard Cross Cultural Sample (Murdock and White, 1969) in order to link each language to the ethnographic data of its aboriginal speakers.

\subsubsection{Periphrastic Future Tense}

Languages differ in the structure of their future tense. In particular, linguists distinguish between languages that are characterized by an inflectional versus periphrastic future tense (Dahl, 1985, 2000; Dahl and Velupillai, 2013). Inflectional future tense is associated with verbs that display morphological variation (i.e., a change in the verb form that is associated with the future tense). In contrast, periphrastic future tense is characterized by roundabout or discursive phrases (e.g., expressions such as 'will', 'shall', 'want to', 'going to' in the English language) (Bybee and Pagliuca, 1987; Bybee and Dahl, 1989; Bybee et al., 1994).

As argued by Bybee and Dahl (1989), unlike inflectional future tense, periphrastic future tense are formed by terms that express a desire, an intention, an obligation, a commitment as well as a movement towards a goal. In particular, in the case of English, "shall has developed from a main verb meaning 'to owe', will from a main verb meaning 'to want', and the source of be going to is still transparent" (Bybee and Dahl, 1989, p.90).

Moreover, "intention and prediction are most commonly expressed by the periphrastic future, while the synthetic one is more common in generic statements, concessives, and suppositions" (Bybee et al., 1994, p.235). Inflectional futures "also appear systematically (often obligatorily) in sentences which express clear predictions about the future (which are independent of human intentions and planning), whereas less grammaticalized constructions [i.e., periphrastic] often tend to be predominantly used in talk of plans and intentions - a fact which is explainable from the diachronic sources of future tenses" (Dahl and Velupillai, 2013, p.270). Thus, periphrastic future tense captures long-term oriented intentions.

Dahl and Velupillai (2013) provide data on the structure of the future tense in 222 languages. The

\footnotetext{
${ }^{9}$ Thus, the linguistic homeland of Spanish is Spain rather than the regions that speak Spanish outside of Spain.
} 
analysis expands this set of languages using data from Dahl $(1985,2000)$. The expanded dataset on the existence of periphrastic future tense includes a total of 275 contemporary languages, from 76 different language families. ${ }^{10}$ Table D.1 and Figure 1 describe the distribution of the structure of future tense in the dataset. They demonstrate wide regional variations in the structure of the future tense. In particular, in most regions about $50 \%$ of the languages in the sample have periphrastic future tense.

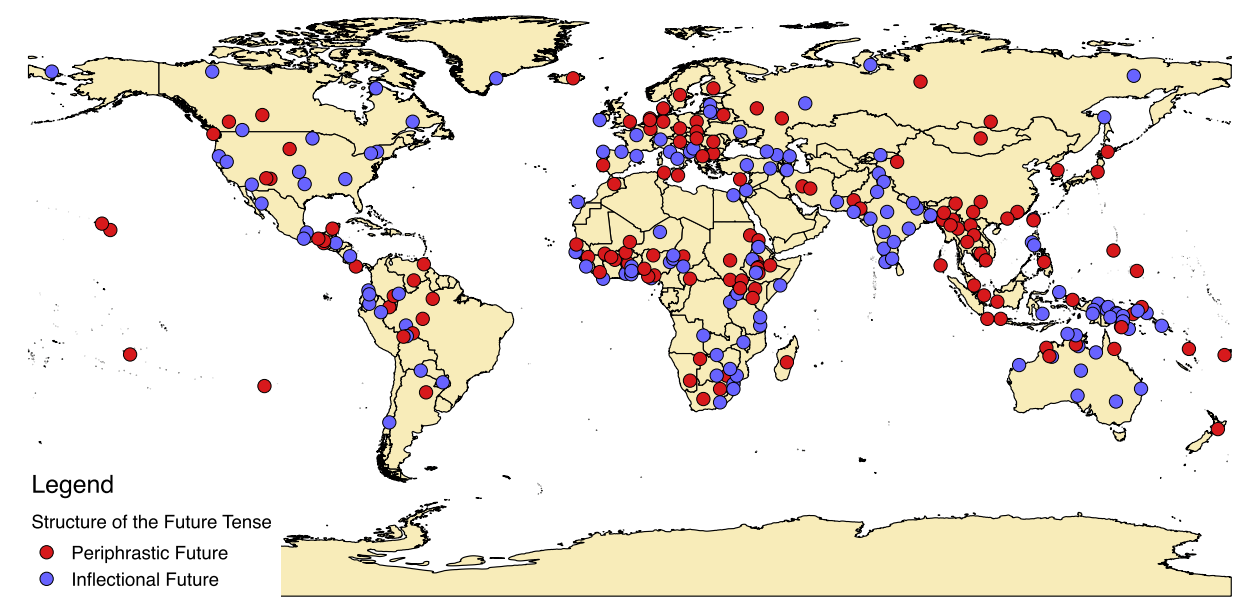

Figure 1: Global Distribution of Inflectional Future Tense

\subsubsection{Sex-Based Grammatical Gender Systems}

Sex-based grammatical gender systems vary across languages. Corbett (2013) provides data on sexbased grammatical gender systems for 227 languages across 76 language families. Table D.2 and Figure 2 describe the distribution of this measure of sex-based grammatical gender systems in the dataset. They demonstrate wide regional variations in the existence of sex-based grammatical gender systems. In particular, about $37 \%$ of the languages in the sample do have a sex-based grammatical gender systems.

\subsubsection{Politeness Distinctions in Pronouns}

Politeness distinctions in pronouns (e.g., "tu" and "usted" in Spanish, "Du" and "Sie" in German, and "tu" and "vous" in French) vary across languages. Helmbrecht (2013) provides data on secondperson politeness distinctions for 207 languages across 69 language families. Table D.3 and Figure 3 describe the distribution of this measure of politeness distinctions in the dataset. They demonstrate wide regional variations in the existence of politeness distinctions. In particular, about $34 \%$ of the languages in the sample do have a politeness distinctions.

\footnotetext{
${ }^{10}$ Importantly, $90 \%$ of languages included in Ethnologue belong to these families, which constitute about $1 / 3$ of all language families in Ethnologue. Many linguistic genera or families only have one language in either WALS or Ethnologue, which mostly precludes the analysis from using within-genus or within-family variation.
} 


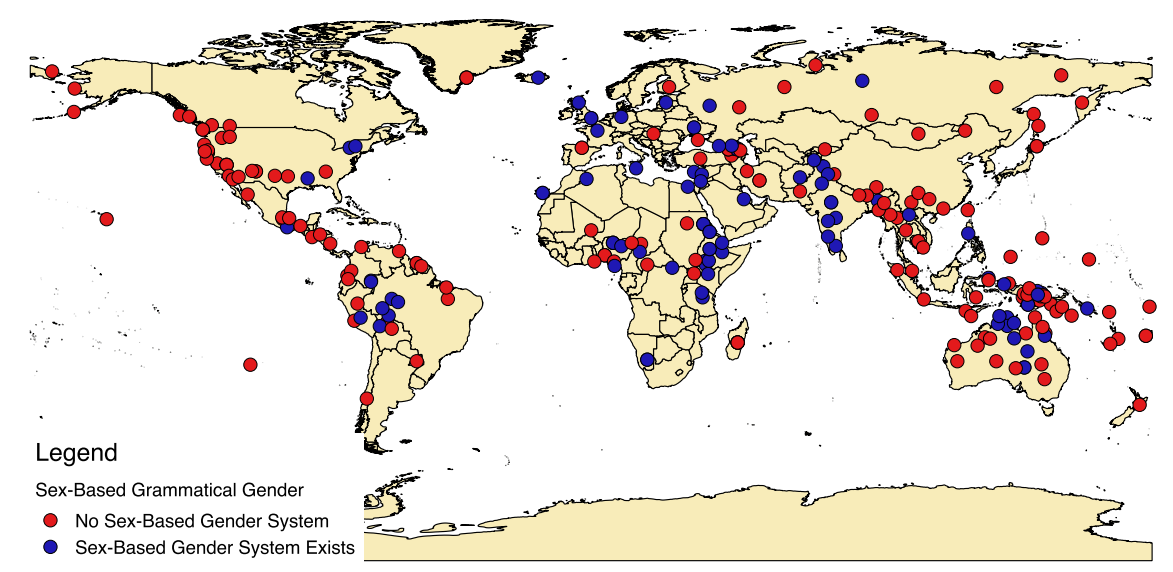

Figure 2: Global Distribution of Sex-Based Grammatical Gender System

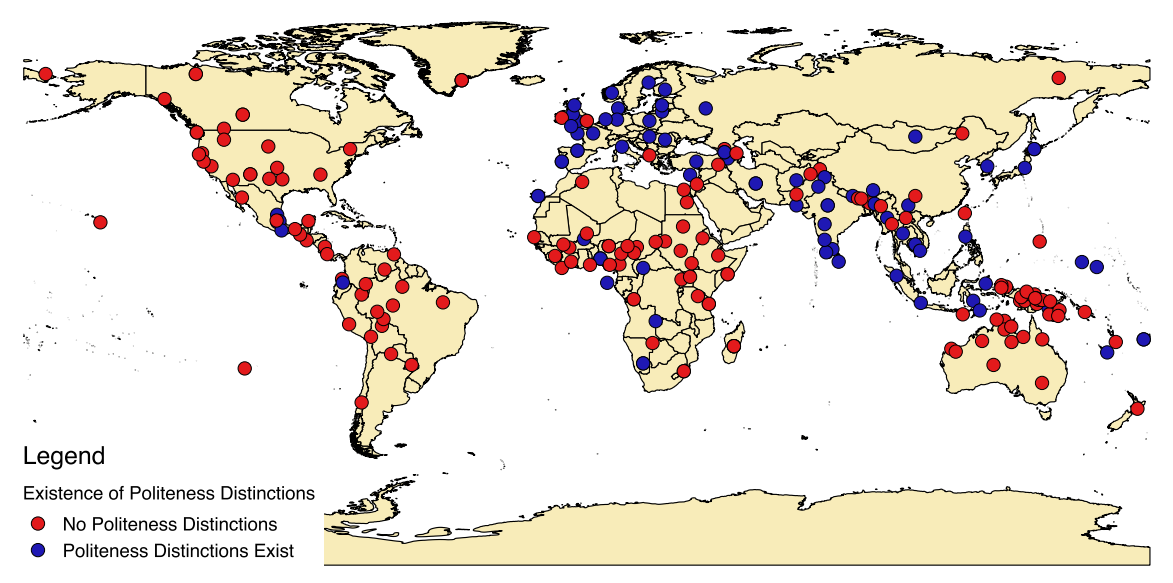

Figure 3: Global Distribution of Politeness Distinctions

\subsection{Main Independent Variables}

\subsubsection{Pre-1500 CE Crop Return}

This subsection introduces the historical potential crop return in a linguistic homeland, which is the hypothesized geographical origin of the future tense. In particular, the historical potential crop return in a location measures the potential daily calories from cultivating the crop with maximal caloric yield during the pre-1500CE era in that location. These measures are based on the Caloric Suitability Index - CSI - (Galor and Özak, 2015, 2016), which provide measures of historical (pre-1500CE) potential crop yield and growth cycles for each grid across the globe.

The measures of historical crop yield and growth cycles constructed by Galor and Özak (2016, 2015) are based on data from the Global Agro-Ecological Zones (GAEZ) project of the Food and Agriculture Organization (FAO), which supplies global estimates of crop yield and crop growth cycle for 48 crops in grids with cells size of $5^{\prime} \times 5^{\prime}$ (i.e., approximately $100 \mathrm{~km}^{2}$ ). Moreover, the CSI measures are based on the agro-climatic estimates under low level of inputs and rain-fed agriculture. ${ }^{11}$ These

\footnotetext{
${ }^{11}$ For each crop, GAEZ provides estimates for crop yield based on three alternative levels of inputs - high, medium, and low - and two possible sources of water supply - rain-fed and irrigation. Additionally, for each input-water source
} 
restrictions remove the potential concern that the level of agricultural inputs, the irrigation method, and soil quality, reflect endogenous choices that could be potentially correlated with time preference (or other cultural traits), and thus, with the structure of the future tense.

In order to capture the nutritional differences across crops, and thus, to ensure comparability of yields across crops, Galor and Özak $(2016,2015)$ convert each crop's yield in the GAEZ data (measured in tons, per hectare, per year), into caloric yield (measured in millions of kilo calories, per hectare, per year) using the caloric content of crops provided by the United States Department of Agriculture Nutrient Database for Standard Reference. Given the caloric yield of each crop in a cell, Galor and Özak $(2016,2015)$ assign to each cell the yield and growth cycle of the crop that maximizes the yield in that cell.

The analysis employs the potential pre-1500 caloric yield and crop growth cycle to construct a potential pre-1500CE caloric return index for each linguistic homeland. In particular, the analysis assigns to each linguistic homeland the average pre-1500CE daily caloric return per hectare (Galor and Özak, 2016). More specifically, the potential pre-1500CE caloric return per hectare per day in the homeland of language $\ell, R_{\ell}$, is given by

$$
R_{\ell}=\frac{1}{\left|C_{\ell}\right|} \sum_{c \in C_{\ell}}\left(\frac{y_{c}}{g_{c}}\right),
$$

where $C_{\ell}$ is the set of cells in the homeland of language $\ell,\left|C_{\ell}\right|$ is the cardinality of this set, $y_{c}$ and $g_{c}$ are the potential pre-1500CE crop yield and growth cycle in cell $c$ of the crop that maximizes caloric output in that cell. Figure 4 depicts the global distribution of the potential pre-1500CE crop return at the cell level.

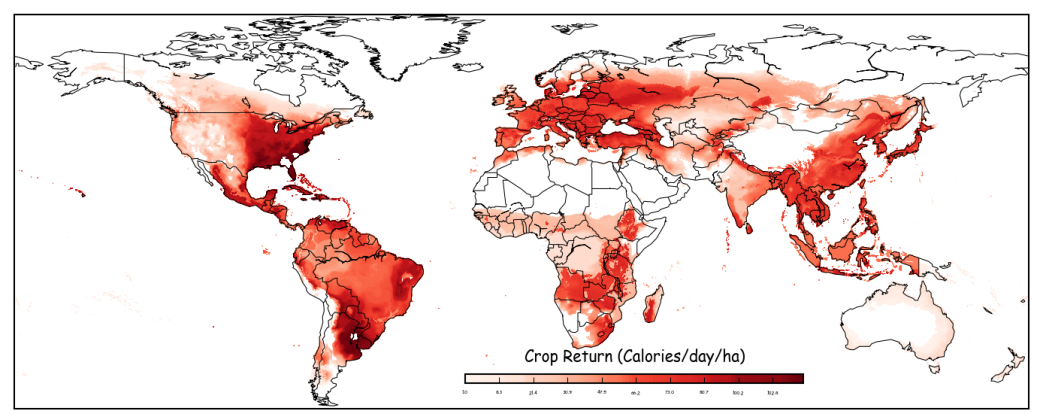

Figure 4: Crop Return (Pre-1500CE)

category, it provides two separate estimates for crop yield, based on agro-climatic conditions, that are arguably unaffected by human intervention, and agro-ecological constraints, that could potentially reflect human intervention. The FAO dataset provides for each cell in the agro-climatic grid the potential yield for each crop (measured in tons, per hectare, per year). These estimates account for the effect of temperature and moisture on the growth of the crop, the impact of pests, diseases and weeds on the yield, as well as climatic related "workability constraints". In addition, each cell provides estimates for the growth cycle for each crop, capturing the days elapsed from the planting to full maturity. 


\subsubsection{Ecological Diversity \& Geographical Attributes Suitable for the use of the Plow}

In view of the hypothesized geographical origins of politeness distinctions and grammatical gender, this subsection introduces measures of ecological diversity in each linguistic homeland as well as measures of the degree of complementarity between the geographical characteristics in each linguistic homeland and the potential use of the plow.

Following Fenske (2014), ecological diversity within a linguistic homeland is a Herfindahl index of the share of each territory that is occupied by different ecological zones. In particular, the ecological diversity $E$ in the homeland of language $\ell$ is

$$
E_{\ell}=1-\sum_{j=1}^{16}\left(\theta_{\ell j}\right)^{2}
$$

where $\theta_{\ell j}$ is the share of the homeland of language $\ell$ in ecological zone $j, j=1, \ldots, 16 .^{12}$

Furthermore, in order to capture the complementarity between the geographical environment and the use of the plow, following the methodology of Galor and Özak (2015, 2016), the analysis constructs measures of average caloric yield across crops that are suitable for the use of the plow (i.e., plow positive crops) and those that are unsuitable (i.e., plow negative crops) as classified by Pryor (1985). ${ }^{13}$ Figure 5 depicts the global distribution of these two measures.

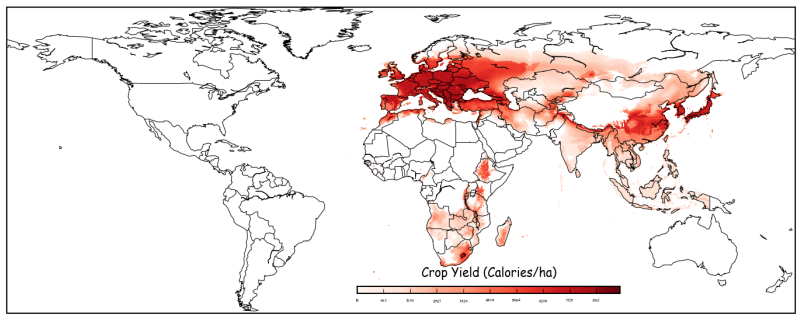

(a) Average Caloric Yield for Plow Positive Crops

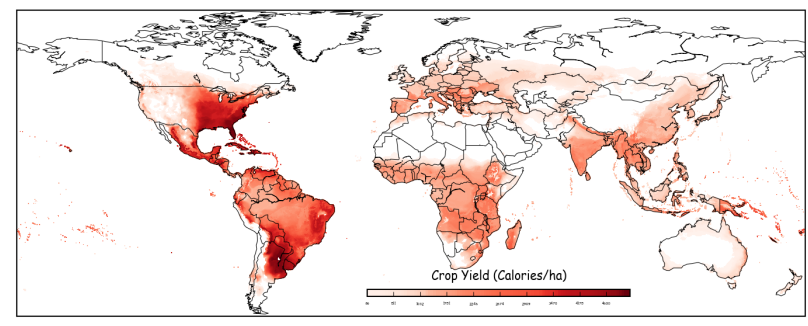

(b) Average Caloric Yield for Plow Negative Crops

Figure 5: Average Caloric Suitability Index (Pre-1500CE) for Crops that are Complementary (Plow Positive) and not Complementary (Plow Negative) to the use of the Plow

\subsection{Additional Controls}

The measures of crop return, plow suitability and ecological diversity may potentially be correlated with other geographical characteristics that may have affected the evolution of the future tense. Hence,

\footnotetext{
${ }^{12}$ Olson et al. (2001) provide a global dataset of biomes with 16 ecological zones: Boreal Forests/Taiga; Deserts and Xeric Shrublands; Flooded Grasslands and Savannas; Inland Water; Mangroves; Mediterranean Forests, Woodlands and Scrub; Montane Grasslands and Shrublands; Rock and Ice; Temperate Broadleaf and Mixed Forests; Temperate Conifer Forests; Temperate Grasslands, Savannas and Shrublands; Tropical and Subtropical Coniferous Forests; Tropical and Subtropical Dry Broadleaf Forests; Tropical and Subtropical Grasslands, Savannas and Shrublands; Tropical and Subtropical Moist Broadleaf Forests; Tundra.

${ }^{13}$ Plow positive crops include wheat, barley, rye, buckwheat, teff, and wet rice. Plow negative crops include grains (such as millet, sorghum, dry rice, and maize), all root crops and tree crops. Similar (non-caloric based measures) were computed by Alesina et al. (2013).
} 
the analysis accounts for the potential confounding effects of a wide range of geographical factors of the linguistic homeland such as absolute latitude, average elevation, terrain ruggedness, coast length, climatic conditions (average, standard deviation, volatility and spatial correlation) such as temperature and precipitation. ${ }^{14}$ Additionally, the analysis accounts for the length of the unproductive period, which measures the potential number of days between the last harvest in one year and the first harvest of the next, in order to account for additional effects that agriculture and its temporal structure might have on the structure of the future. ${ }^{15}$

Furthermore, the analysis accounts for regional fixed-effects, capturing unobserved region-specific geographical and historical characteristics that may have codetermined the global distribution of the future tense. Moreover, for each language the analysis employs additional data on its language structures, taken from WALS (Dryer, 2013), in order to overcome the potential concern that the results are driven by a general characteristic of a language. Finally, for each language, the analysis employs ethnographic data on its speakers from the Ethnographic Atlas and the Standard Cross-Cultural Sample (Murdock, 1967; Murdock and White, 1969) in order to analyze the mechanisms suggested by the theory.

\section{The Geographical Origins of Language Structures}

This section explores the empirical relation between language structures and their hypothesized geographical determinants. In particular, it explores the association between (i) the historical return to investment in agriculture and the existence of periphrastic future tense, (ii) geographical characteristics that are not suitable for the cultivation of crops that are complementary to the use of the plow and the existence of sex-based grammatical gender, and (iii) ecological diversity and the existence of politeness distinctions across languages as well as language families.

\subsection{Empirical Strategy}

In order to explore this relation, the following empirical specification is estimated via a probit model:

$$
P\left(S_{\ell} \mid R_{\ell},\left\{X_{\ell j}\right\},\left\{\delta_{c}\right\}\right)=\Phi\left(\beta_{0}+\beta_{1} R_{\ell}+\sum_{j} \gamma_{0 j} X_{\ell j}+\sum_{c} \gamma_{c} \delta_{\ell c}\right),
$$

where $S_{\ell}$ indicates whether structure $S=$ ( periphrastic future tense, sex-based grammatical gender, politeness distinctions) exists in language $\ell, R_{\ell}$ denotes the hypothesized geographical determinant of structure $S_{\ell}$ (i.e., pre-1500CE crop return, average caloric yield of plow negative crops, ecological diversity) in the homeland of language $\ell ;\left\{X_{\ell j}\right\}$ is a set of additional geographical characteristics of the homeland of language $\ell ;\left\{\delta_{\ell c}\right\}$ is a complete set of regional fixed-effects. For robustness and also in order to develop additional analyses, the research also estimates a Linear Probability Model by means of Ordinary Least Squares (OLS).

\footnotetext{
${ }^{14}$ The summary statistics and description of all variables used in the analysis is provided in Table D.4.

${ }^{15}$ This captures the effect of winter in temperate regions, and similar effects in other parts of the world.
} 
The identification of the effect of the hypothesized geographical determinant of structure $S_{\ell}, R_{\ell}$, on the language structure $S_{\ell}$ is subject to various potential concerns. First, if as proposed by the theory, $S_{\ell}$ encodes a cultural trait $C$ (e.g., periphrastic future tense encodes time preference and long-term orientation), the estimated effect may reflect the consequences of variations in the latter on human behavior (e.g., the choice of technologies) and therefore actual levels of $R_{\ell}$ (e.g., crop returns). Hence, to overcome this concern about reverse causality, this research exploits variations in $R_{\ell}$ that are (mostly) orthogonal to human intervention (e.g., potential rather than actual crop returns associated with agro-climatic conditions).

Second, the results may be biased by omitted geographical, institutional, cultural, or human characteristics that might have determined cultural trait $C$ (e.g., time preference and long-term orientation) and are correlated with $R_{\ell}$. Thus, several strategies are employed to mitigate this concern: (i) The analysis accounts for a large set of confounding geographical characteristics (e.g., absolute latitude, average elevation, terrain ruggedness, coast length, and climatic conditions measured by the average, standard deviation, volatility and spatial correlation of temperature and precipitation). (ii) It accounts for regional fixed-effects, capturing unobserved time-invariant heterogeneity at the regional level. (iii) It explores the size and sign of the potential bias generated by omitted factors.

\subsection{The Origins of Periphrastic Future Tense}

The proposed hypothesis suggests that in societies characterized by higher long-term orientation, the periphrastic future tense and its associated commitment towards future actions may have emerged and persisted over time, fortifying existing inclinations towards the future. Thus, in view of the established positive relationship between crop return and long-term orientation (Galor and Özak, 2016), crop return would be expected to affect the existence of periphrastic future tense and may be the geographical origin of this grammatical structure.

This section analyzes the relation between crop return and the emergence of periphrastic future tense using contemporary languages as the unit of analysis. In particular, Table 1 explores the effect of the pre-1500CE crop return on the existence of periphrastic future tense in a language for the full sample of languages. ${ }^{16}$ Column (1) shows the unconditional correlation between the pre-1500CE crop return and the existence of periphrastic future tense. The estimated coefficient is positive and statistically significant at the $5 \%$, and suggests that a one standard deviation increase in crop return increases the probability of having periphrastic future tense in a language by $6 \%$.

Column (2) accounts for regional fixed-effects and, therefore, for any unobserved time-invariant heterogeneity at the regional level. Reassuringly, the coefficient on pre-1500CE crop return becomes larger and increases its statistical significance, suggesting that unobserved time-invariant factors at the regional level may have biased the coefficient towards zero. The estimated coefficient suggests that a one standard deviation increase in crop return is associated with an $8 \%$ increase in the probability of having periphrastic future tense.

In columns (3)-(6) the analysis accounts also for other potential confounding geographical characteristics of the linguistic homelands. In particular, the analysis accounts for the homeland's absolute

\footnotetext{
${ }^{16}$ Table A.1 shows that the results are similar when using the linear probability model (OLS).
} 
Table 1: Crop Return and Periphrastic Future Tense (Probit)

\begin{tabular}{|c|c|c|c|c|c|c|c|c|c|}
\hline & \multicolumn{9}{|c|}{ Existence of Periphrastic Future Tense } \\
\hline & $(1)$ & $(2)$ & $(3)$ & $(4)$ & $(5)$ & $(6)$ & (7) & $(8)$ & (9) \\
\hline Crop Return (pre-1500CE) & $\begin{array}{l}0.06^{* *} \\
(0.03)\end{array}$ & $\begin{array}{l}0.08^{* *} \\
(0.03)\end{array}$ & $\begin{array}{l}0.08^{* *} \\
(0.03)\end{array}$ & $\begin{array}{l}0.08^{* *} \\
(0.03)\end{array}$ & $\begin{array}{l}0.08^{* *} \\
(0.03)\end{array}$ & $\begin{array}{l}0.08^{* *} \\
(0.03)\end{array}$ & $\begin{array}{l}0.09 * * \\
(0.03)\end{array}$ & $\begin{array}{l}0.09 * * * \\
(0.03)\end{array}$ & $\begin{array}{l}0.12^{* * *} \\
(0.03)\end{array}$ \\
\hline Absolute Latitude & & & $\begin{array}{l}0.10^{*} \\
(0.05)\end{array}$ & $\begin{array}{l}0.10^{*} \\
(0.05)\end{array}$ & $\begin{array}{l}0.10^{*} \\
(0.05)\end{array}$ & $\begin{array}{l}0.08 \\
(0.05)\end{array}$ & $\begin{array}{l}0.07 \\
(0.06)\end{array}$ & $\begin{array}{l}0.09 \\
(0.10)\end{array}$ & $\begin{array}{l}0.13 \\
(0.10)\end{array}$ \\
\hline Elevation & & & & $\begin{array}{l}0.00 \\
(0.03)\end{array}$ & $\begin{array}{l}0.02 \\
(0.04)\end{array}$ & $\begin{array}{l}0.03 \\
(0.04)\end{array}$ & $\begin{array}{l}0.01 \\
(0.04)\end{array}$ & $\begin{array}{l}0.04 \\
(0.05)\end{array}$ & $\begin{array}{l}0.03 \\
(0.05)\end{array}$ \\
\hline Ruggedness & & & & & $\begin{array}{l}-0.04 \\
(0.04)\end{array}$ & $\begin{array}{l}-0.04 \\
(0.04)\end{array}$ & $\begin{array}{l}-0.02 \\
(0.04)\end{array}$ & $\begin{array}{l}-0.02 \\
(0.05)\end{array}$ & $\begin{array}{l}-0.02 \\
(0.04)\end{array}$ \\
\hline Coast Length & & & & & & $\begin{array}{l}0.10^{* * *} \\
(0.03)\end{array}$ & $\begin{array}{l}0.08^{* * *} \\
(0.03)\end{array}$ & $\begin{array}{l}0.07^{* *} \\
(0.03)\end{array}$ & $\begin{array}{l}0.08^{* *} \\
(0.04)\end{array}$ \\
\hline Precipitation (mm/month) & & & & & & & $\begin{array}{l}-0.00 \\
(0.08)\end{array}$ & $\begin{array}{l}-0.01 \\
(0.08)\end{array}$ & $\begin{array}{l}0.00 \\
(0.08)\end{array}$ \\
\hline Precipitation $(\mathrm{mm} / \mathrm{month})(\mathrm{std})$ & & & & & & & $\begin{array}{l}0.09^{* * *} \\
(0.04)\end{array}$ & $\begin{array}{l}0.05 \\
(0.06)\end{array}$ & $\begin{array}{l}0.05 \\
(0.05)\end{array}$ \\
\hline Precipitation Volatility & & & & & & & $\begin{array}{l}-0.05 \\
(0.08)\end{array}$ & $\begin{array}{l}-0.03 \\
(0.08)\end{array}$ & $\begin{array}{l}-0.04 \\
(0.08)\end{array}$ \\
\hline Precipitation Spatial Correlation & & & & & & & $\begin{array}{l}0.02 \\
(0.04)\end{array}$ & $\begin{array}{l}1.05^{* * *} \\
(0.31)\end{array}$ & $\begin{array}{l}0.97^{* * *} \\
(0.31)\end{array}$ \\
\hline Temperature (Daily Mean) & & & & & & & & $\begin{array}{l}0.06 \\
(0.08)\end{array}$ & $\begin{array}{l}0.06 \\
(0.08)\end{array}$ \\
\hline Temperature (Daily Mean) (std) & & & & & & & & $\begin{array}{l}0.05 \\
(0.05)\end{array}$ & $\begin{array}{l}0.05 \\
(0.05)\end{array}$ \\
\hline Temperature Volatility & & & & & & & & $\begin{array}{l}-0.04 \\
(0.09)\end{array}$ & $\begin{array}{l}-0.08 \\
(0.09)\end{array}$ \\
\hline Temperature Spatial Correlation & & & & & & & & $\begin{array}{l}-1.04^{* * *} \\
(0.31)\end{array}$ & $\begin{array}{l}-0.96^{* * *} \\
(0.31)\end{array}$ \\
\hline Unproductive Period (pre-1500CE) & & & & & & & & & $\begin{array}{l}0.10^{* * *} \\
(0.03)\end{array}$ \\
\hline Regional FE & No & Yes & Yes & Yes & Yes & Yes & Yes & Yes & Yes \\
\hline Pseudo- $R^{2}$ & 0.01 & 0.04 & 0.05 & 0.05 & 0.05 & 0.07 & 0.09 & 0.12 & 0.14 \\
\hline Observations & 275 & 275 & 275 & 275 & 275 & 275 & 275 & 275 & 275 \\
\hline
\end{tabular}

Notes: This table establishes the positive, statistically, and economically significant effect of a region's pre-1500CE potential crop return on the existence of periphrastic future tense in the language spoken in this region, accounting for regional fixedeffects and other geographical characteristics. Geographical controls include absolute latitude, mean elevation, terrain ruggedness, and coast length, as well as other agriculture-related controls as precipitation and temperature means and standard deviations. All independent variables have been normalized by subtracting their mean and dividing by their standard deviation. Thus, all coefficients can be compared and show the effect of a one standard deviation in the independent variable on the probability of having a future tense in the language. Heteroskedasticity robust standard error estimates are reported in parentheses; $* * *$ denotes statistical significance at the $1 \%$ level, ${ }^{* *}$ at the $5 \%$ level, and $*$ at the $10 \%$ level, all for two-sided hypothesis tests.

latitude, mean elevation above sea level, terrain ruggedness, and the length of its sea coast. Reassuringly, accounting for the effects of these geographical factors and unobserved regional heterogeneity does not alter the results.

Columns (7) and (8) additionally account for the potential confounding effects of climate as captured by measures of temperature and precipitation. In particular, given that the pre-1500CE crop return is based on climatic factors, it might be capturing any potential direct effects of (average) climate on the existence of periphrastic future. Moreover, variability of climate may affect the riskiness of agricultural investment, thus reducing any potential effects of crop return. Nevertheless, accounting 
for the effect of average temperature and precipitation, their standard deviations and volatility, and the potential for spatial diversification of risk due to precipitation and temperature does not alter the qualitative results. Accounting for all of these climatic characteristics does not change the magnitude of the coefficient of the crop return, but increases its statistical significant to the $1 \%$ level. Furthermore, most of the controls have no significant effect on the emergence of future tense.

Finally, given that the periphrastic future tense might be associated with planning in general, and in agriculture in particular, the relation between existence of periphrastic future and historical crop return might spuriously be capturing, e.g., the effect of the length of the time between crop harvests. In order to overcome this potential concern, column (9) accounts for the number of days between the last harvest in one year and the first potentially feasible harvest in the following year. Hence, during this period a region is not agriculturally productive and people are forced to plan for survival during this period. Reassuringly, accounting for this unproductive period does not alter the main result. In fact, the coefficient becomes even more economically and statistically significant. In particular, its magnitude (in absolute value) is the largest obtained in the analysis and suggests that a one standard deviation increase in pre- $1500 \mathrm{CE}$ crop return is associated with a $12 \%$ increase in the probability of having periphrastic future tense. Moreover, the effect of the unproductive period is also positive and economically and statistically significant, suggesting that planning for the future has a similar effect on the existence of periphrastic future tense as crop return. ${ }^{17}$

These results lend credence to the idea that crop return, through its effect on time preference and long-term oriented behavior, increases the probability of existence of a periphrastic future tense in a language. Moreover, additional sources of variation in the requirements for planning, as captured by the yearly agricultural unproductive period, also are associated with an increase in the probability of existence of periphrastic future tense. Still, the results might be biased due to omitted variables, precluding a causal interpretation of the estimated coefficients.

\subsubsection{Robustness to Omitted Variables, Clustering and Spatial-Autocorrelation}

This section explores the robustness of the previous results to omitted variables, clustering and spatial auto-correlation. In particular, as mentioned above, omitted variables can potentially bias the estimated effect of pre-1500CE crop return on the probability of existence of periphrastic future tense in a language. Moreover, the existence of periphrastic future tense might not be independent across languages that belong to the same language genus or that are spatially closely located.

In order to analyze these issues further, Table 2 replicates the analysis of Table 1 using a Linear Probability Model. Interestingly, the estimated average marginal effects of the probit model in Table 1 are identical to the estimated effects using OLS. Additionally, Table 2 establishes the robustness of the results to clustering at the language genus level and to spatial auto-correlation. In particular, in all columns the statistical significance of the results is not affected by the method used to overcome the concerns due to the potential violation of the independence assumption.

\footnotetext{
${ }^{17}$ Nevertheless, the analysis reveals that unlike the crop return, the relation between the unproductive period and the existence of a future tense is not robust to the other specifications analyzed in Table 1 , and its semi-partial $R^{2}$ is very low.
} 
Table 2: Crop Return and Periphrastic Future Tense (OLS)

Robustness to Spatial-Autocorrelation, Clustering and Omitted Variables

\begin{tabular}{llllllllll}
\hline \hline & \multicolumn{7}{c}{ Existence of Periphrastic Future Tense } \\
\cline { 2 - 9 } & \multicolumn{1}{c}{$(1)$} & $(2)$ & $(3)$ & $(4)$ & $(5)$ & $(6)$ & $(7)$ & $(8)$ & $(9)$ \\
\hline Crop Return (pre-1500CE) & $0.06^{* *}$ & $0.08^{* *}$ & $0.08^{* *}$ & $0.08^{* *}$ & $0.09^{* *}$ & $0.08^{* *}$ & $0.09^{* *}$ & $0.09^{* *}$ & $0.12^{* * *}$ \\
& $(0.03)$ & $(0.03)$ & $(0.03)$ & $(0.03)$ & $(0.03)$ & $(0.03)$ & $(0.04)$ & $(0.03)$ & $(0.03)$ \\
& $([0.04])$ & $([0.04])$ & $([0.04])$ & $([0.04])$ & $([0.04])$ & $([0.04])$ & $([0.04])$ & $([0.04])$ & $([0.03])$ \\
& {$[0.04]$} & {$[0.04]$} & {$[0.04]$} & {$[0.04]$} & {$[0.04]$} & {$[0.04]$} & {$[0.04]$} & {$[0.04]$} & {$[0.03]$} \\
& $\{0.03\}$ & $\{0.03\}$ & $\{0.03\}$ & $\{0.03\}$ & $\{0.03\}$ & $\{0.03\}$ & $\{0.03\}$ & $\{0.03\}$ & $\{0.03\}$ \\
\hline Regional FE & No & Yes & Yes & Yes & Yes & Yes & Yes & Yes & Yes \\
Altonji et al & & -4.14 & -3.86 & -3.86 & -3.45 & -3.55 & -3.28 & -3.16 & -2.09 \\
$\delta$ & & -0.32 & -0.40 & -0.40 & -0.37 & -0.55 & -0.67 & -1.05 & -0.75 \\
$\beta$-Oster & & 0.28 & 0.25 & 0.25 & 0.27 & 0.21 & 0.20 & 0.16 & 0.23 \\
$R^{2}$ & 0.01 & 0.06 & 0.07 & 0.07 & 0.07 & 0.09 & 0.11 & 0.15 & 0.17 \\
Adjusted- $R^{2}$ & 0.01 & 0.03 & 0.04 & 0.04 & 0.04 & 0.05 & 0.06 & 0.09 & 0.11 \\
Observations & 275 & 275 & 275 & 275 & 275 & 275 & 275 & 275 & 275 \\
\hline
\end{tabular}

Notes: This table shows the robustness of the results to selection by unobservables. It presents the Altonji et al. (2005) AET ratio as extended by Bellows and Miguel (2009). Additionally, it presents the $\delta$ and $\beta^{*}(1,1)$ statistics suggested by Oster (2014). All statistics suggest that the results are not driven by unobservables. Heteroskedasticity robust standard error estimates are reported in parentheses, clustered at the language genus in parenthesis and squared brackets, spatial autocorrelation corrected standard errors (Conley, 1999) in squared brackets and Cliff-Ord ML in curly brackets; *** denotes statistical significance at the $1 \%$ level, ${ }^{* *}$ at the $5 \%$ level, and $*$ at the $10 \%$ level, all for two-sided hypothesis tests.

Furthermore, Table 2 explores the size and sign of the potential bias generated by omitted variables. In particular, using statistics on the selection on observables and unobservables (Altonji et al., 2005; Bellows and Miguel, 2009; Oster, 2014), it establishes that the degree of omitted variable bias is low and is unlikely to explain the size of the estimated effect of crop return. More specifically, the research analyzes the change in the estimated coefficient once observables are controlled for. The results suggest that omitted factors would need to be 1-4 times more strongly negatively correlated with crop return than all the controls accounted for in order to explain the estimated effect of the crop return on the emergence of the future tense. Thus, the estimated coefficient should be considered a lower bound of the true effect.

Thus, the analysis suggests that the true effect of historical returns to agricultural investment on the probability of existence of periphrastic future in a language is economically and statistically significant. Indeed, in all specifications, the bias-adjusted estimated effect of pre-1500CE crop return is strictly positive and at least twice as large than the OLS estimate (Oster, 2014). In particular, the bias corrected estimate in column 9, which assumes the unobservables are as strongly correlated with pre-1500CE crop return as the set of observables accounted for, implies that a one standard deviation increase in crop return increases the probability of existence of periphrastic future tense by $25 \%$.

\subsubsection{Crop Return and Other Language Structures}

A potential concern with the previous results, is that the pre- $1500 \mathrm{CE}$ crop return in a linguistic homeland might be capturing some general aspect about a language and the culture of the people who speak it. This concern is partially mitigated by the results of Galor and Özak (2016) who established 
that pre-1500CE crop return only affects time preference and does not have a significant effect on the other cultural traits studied by them. Still, it is possible that time preference and long-term orientation are reflected in other aspects or structures of a language or that crop return is associated with cultural traits not previously studied.

In order to address this potential concern, Table 3 explores the relation between pre-1500CE crop return and other temporal and non-temporal structures in a language. Given that not all the outcomes are binary, the analysis in Table 3 uses OLS in order to estimate the various relations. Column (1) replicates the analysis of column (9) in Tables 1 and A.1 for comparison. As previously established, pre-1500CE crop return is economically and statistically significantly positively associated with the existence of periphrastic future tense. Columns (2) and (3) examine whether crop return is associated with other tenses and aspects in the verbal system, specifically with the existence of a past tense and a perfect tense. The results suggest that crop return is not statistically significantly associated with these additional temporal structures of language.

Table 3: Crop Return and Language Structures

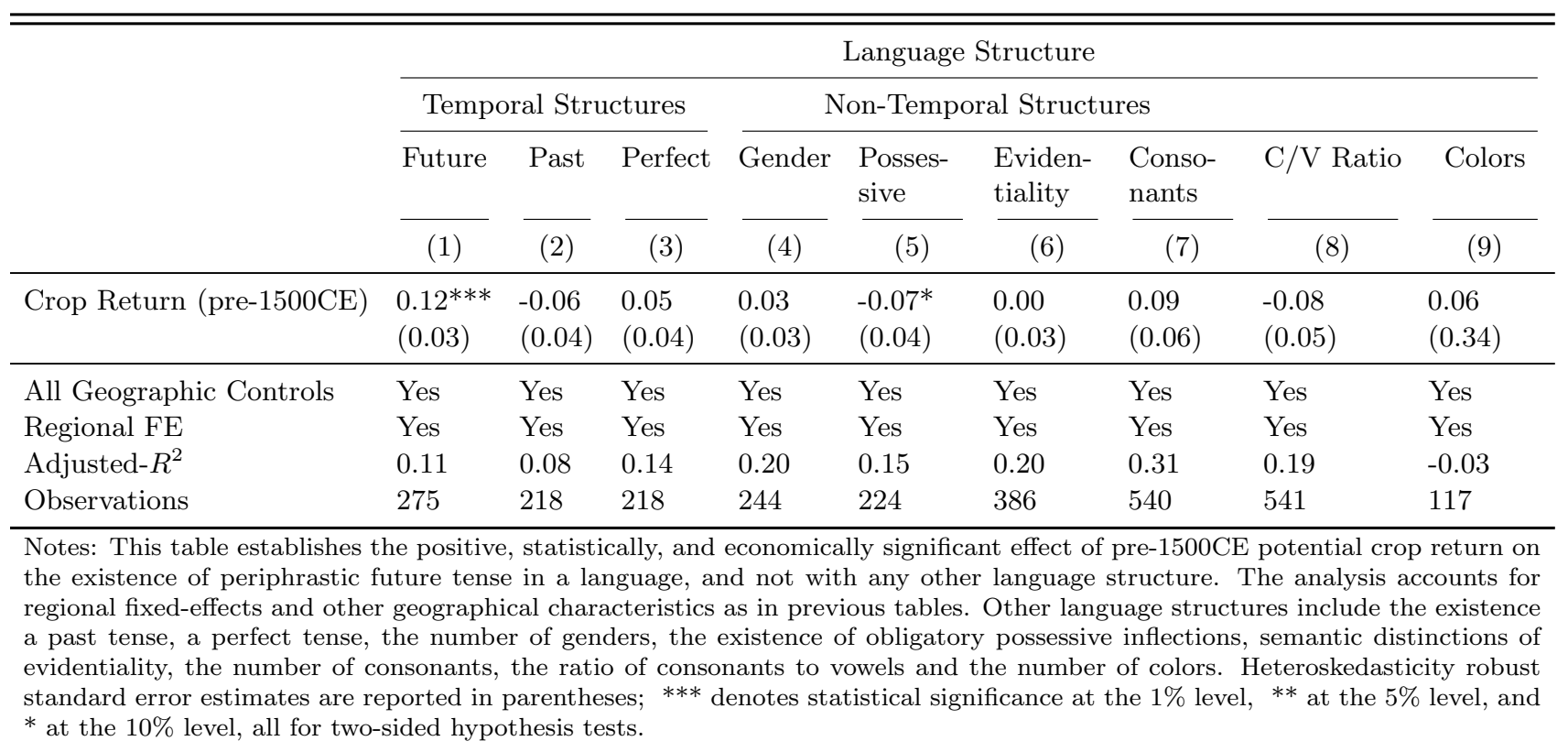

Similarly, columns (4)-(9) explore the relation between pre-1500CE crop return and other nontemporal characteristics of a language such as (i) the number of gender distinctions it has, (ii) whether its has possessive classifications, (iii) whether it has coding for evidentiality, (iv) the number of consonants, (v) the ratio of consonants to vowels, and (vi) the number of colors in the language (Dryer, 2013). Again, crop return does not have a statistically significant association with any of these structures. ${ }^{18}$

These results suggest that crop return is not significantly associated with other temporal and non-temporal structures of languages. On the contrary, pre-1500CE crop return is statistically and economically significantly associated only with the existence of periphrastic future tense. Thus, in

\footnotetext{
${ }^{18}$ The results are even stronger if one estimates a Probit model for the language structures that are coded as binary response variables. In particular, the possessive structure is not statistically significantly associated with crop return even at the $15 \%$ significance.
} 
consonance with the evidence of Galor and Özak (2016), these results support the hypothesis that pre-1500CE crop return only affects time preference and long-term orientation, which are reflected only in the future tense.

\subsubsection{Persistent Effect of Crop Return in Languages' Ancestral Homeland}

In light of the view that contemporary languages within a language family descend from a common proto-language, if periphrastic future tense started forming during these pre-historic times, the theory suggests that the crop return in the ancestral homeland of the proto-language (i.e., the Urheimat of a language family) would be expected to have a persistent effect on the presence of periphrastic future tense in its daughter languages. Similarly, crop return in the Urheimat should have a persistent effect on the share of languages with future tense within a language family.

Table 4 explores the association between pre-1500CE crop return in a language family's Urheimat and the probability that a daughter language has periphrastic future tense. ${ }^{19}$ Column (1) shows the positive and significant unconditional association between the crop return in a language family's Urheimat and the existence of periphrastic future tense in a daughter language. The estimated coefficient is twice as large as the one established in column (1) in Table 1, suggesting a stronger association between the existence of a future tense and crop return in the Urheimat compared to the contemporary homeland of the daughter language. Moreover, the explanatory power of the Urheimat's crop return is larger than the one of the contemporary homeland. In fact, the pseudo- $R^{2}$ and semi-partial $R^{2}$ of the Urheimat's crop return are 4 and 20 times larger, respectively, than the ones corresponding to the return in the contemporary homeland.

Column (2) establishes that once additional geographical characteristics of the Urheimat as well as time invariant regional unobserved heterogeneity are accounted for, the estimated coefficient on crop return increases by $61 \%$. Thus, the estimated coefficient on crop return in a language's Urheimat is twice the size of the estimated effect of the crop return in its contemporary homeland (column (9) in Table 1). Moreover, the estimated coefficient is similar to the biased adjusted estimated effect in column (9) in Table 2.

Columns (3) and (4) establish that the persistent positive effect of crop return in a language family's Urheimat on the existence of periphrastic future tense in a daughter language remains economically and statistically significant, even after accounting for the change in crop return, as well as in other geographical characteristics, generated by the migration out of the Urheimat and into the language's homeland.

The results in columns (1)-(4) in Table 4 suggest that the origins of periphrastic future tense in contemporary languages are found in cultural processes that took place during the formation of proto-languages. In particular, since contemporary languages are descendants of proto-languages, the analysis in columns (1)-(4) in Table 4 captures the spirit of the analyses that focus on descendants (e.g., second-generation migrants) to identify the effect of culture (Giuliano, 2007; Galor and Özak, 2016).

\footnotetext{
${ }^{19}$ Given the lack of data on the location of a Urheimat for the Khosian family, the analysis in this section excludes this family.
} 
Table 4: Urheimat's Crop Return and Periphrastic Future Tense

\begin{tabular}{|c|c|c|c|c|c|c|c|c|}
\hline & \multicolumn{8}{|c|}{ Existence of Periphrastic Future Tense } \\
\hline & \multicolumn{4}{|c|}{ All Languages } & \multicolumn{4}{|c|}{ Languages In/Near Urheimat } \\
\hline & & & & & All & $\begin{array}{l}\Delta R< \\
0.5 \mathrm{SD}\end{array}$ & $\begin{array}{c}\Delta R< \\
0.25 \mathrm{SD}\end{array}$ & $\begin{array}{c}\Delta R< \\
0.01 \mathrm{SD}\end{array}$ \\
\hline & $(1)$ & $(2)$ & $(3)$ & $(4)$ & $(5)$ & $(6)$ & $(7)$ & $(8)$ \\
\hline Urheimat Crop Return (Pre-1500CE) & $\begin{array}{l}0.13^{* * *} \\
(0.04)\end{array}$ & $\begin{array}{l}0.21^{* * *} \\
(0.06)\end{array}$ & $\begin{array}{l}0.12^{* * *} \\
(0.04)\end{array}$ & $\begin{array}{l}0.20^{* * *} \\
(0.06)\end{array}$ & $\begin{array}{l}0.17^{* * *} \\
(0.06)\end{array}$ & $\begin{array}{l}0.15^{* * *} \\
(0.04)\end{array}$ & $\begin{array}{l}0.20^{* *} \\
(0.08)\end{array}$ & $\begin{array}{l}0.24^{* *} \\
(0.07)\end{array}$ \\
\hline Change in Crop Return & & & $\begin{array}{l}-0.03 \\
(0.05)\end{array}$ & $\begin{array}{l}-0.05 \\
(0.04)\end{array}$ & $\begin{array}{l}-0.07 \\
(0.05)\end{array}$ & $\begin{array}{l}-0.05 \\
(0.17)\end{array}$ & $\begin{array}{c}-0.14 \\
(0.41)\end{array}$ & $\begin{array}{l}-6.62 \\
(31.72)\end{array}$ \\
\hline Regional FE & No & Yes & No & Yes & Yes & Yes & Yes & No \\
\hline Urheimat Geographical Charac. & No & Yes & No & Yes & Yes & Yes & Yes & No \\
\hline Change in Geographical Charac. & No & No & No & Yes & Yes & Yes & Yes & No \\
\hline Pseudo- $R^{2}$ & 0.04 & 0.22 & 0.04 & 0.30 & 0.28 & 0.35 & 0.43 & 0.19 \\
\hline Observations & 273 & 273 & 273 & 273 & 233 & 165 & 120 & 20 \\
\hline Language Families & 75 & 75 & 75 & 75 & 74 & 69 & 56 & 20 \\
\hline
\end{tabular}

Notes: This table explores the association between pre-1500CE crop return in a language family's Urheimat and the probability that a daughter language has a future tense. Heteroskedasticity robust standard error estimates clustered at the language family level are reported in parentheses; *** denotes statistical significance at the $1 \%$ level, ** at the $5 \%$ level, and * at the $10 \%$ level, all for two-sided hypothesis tests.

Finally, the analysis further explores the relative contributions of pre-1500CE crop return in the homeland vs. the Urheimat to the presence of future tense in a daughter language. In particular, Table 5 establishes that the existence of periphrastic future tense among daughter languages located outside the Urheimat of their proto-language is only significantly positively associated with crop return in the Urheimat. Thus, the results further suggest the deep-historical origins of the structure of the future tense and its association with crop return and long-term orientation. In particular, a one standard deviation increase in crop return in the Urheimat is associated with 52 percentage points increase in the probability of existence of a future tense in a daughter language. Importantly, by focusing on languages located outside the Urheimat of their proto-language and accounting for regional fixed-effects, the analysis mirrors the epidemiological approach to cultural diffusion, thus addressing potential concerns regarding omitted variables at the host-region level.

\subsubsection{Sorting}

This section exploits the descent of contemporary languages from proto-languages to explore the relative contributions of the persistent effect of geographical characteristics in the proto-language's homeland and sorting in the course of the demic diffusion of languages on the evolution of periphrastic future tense.

A potential concern with the results in section 3.2.3 is that individuals who spoke languages characterized by the presence (or absence) of periphrastic future tense could have sorted into regions with high return to agricultural investment. Although, this sorting would not affect the nature of the association (i.e., variations in the return to agricultural investment across Urheimats of languages would still be the origin of variations in the existence of periphrastic future tense across languages), 
Table 5: Persistent Effect of Urheimat Characteristics on Periphrastic Future Tense: Languages Outside Urheimat

\begin{tabular}{|c|c|c|c|c|}
\hline & \multicolumn{4}{|c|}{ Existence of Periphrastic Future Tense } \\
\hline & \multicolumn{2}{|c|}{ Homeland } & \multicolumn{2}{|c|}{ Urheimat } \\
\hline & $(1)$ & $(2)$ & $(3)$ & $(4)$ \\
\hline Urheimat Crop Return (Pre-1500CE) & $\begin{array}{l}0.01 \\
(0.06)\end{array}$ & $\begin{array}{l}0.03 \\
(0.04)\end{array}$ & $\begin{array}{l}0.14^{*} \\
(0.07)\end{array}$ & $\begin{array}{l}0.52^{* * *} \\
(0.07)\end{array}$ \\
\hline Regional FE & No & Yes & No & Yes \\
\hline Homeland Geographical Characteristics & No & Yes & No & No \\
\hline Urheimat Geographical Characteristics & No & No & No & Yes \\
\hline Adjusted- $R^{2}$ & -0.01 & 0.12 & 0.04 & 0.17 \\
\hline Observations & 163 & 163 & 163 & 163 \\
\hline Language Families & 19 & 19 & 19 & 19 \\
\hline
\end{tabular}

Notes: This Table explores the relative contributions of pre-1500CE crop return in the homeland vs. the Urheimat to the presence of future tense in a daughter language. Heteroskedasticity robust standard error estimates clustered at the language family level are reported in parentheses; $* * *$ denotes statistical significance at the $1 \%$ level, ** at the $5 \%$ level, and * at the $10 \%$ level, all for two-sided hypothesis tests; All regressions include a constant.

it may alter the cultural interpretation.

The analysis in columns (5)-(8) in Table 4 addresses this potential concern by replicating the analysis for languages that remained in the same region as their Urheimat and had small changes in their crop return. More specifically, by constraining the set of languages to those which remained in the same region as the proto-language, the analysis excludes languages that were subjected to longer migratory processes. Additionally, by constraining the differences in return between the homeland and the Urheimat, the analysis constrains the potential incentives that might have caused people to sort themselves across locations. Reassuringly, the qualitative results remain unchanged, mitigating concerns about the effect of sorting in the course of the demic diffusion of languages on the evolution of periphrastic future tense. Moreover, neither the change in crop return (columns (3)-(8)) nor crop return in the contemporary homeland (Table 5) are associated with the existence of periphrastic future tense, further alleviating concerns about sorting in the observed association.

\subsubsection{Robustness to Sample Selection Bias and Measurement Error}

This section explores the robustness of the analysis to potential sample selection bias and measurement error. In particular, a potential concern with the previous results is that the sample of languages for which data on the existence of periphrastic future tense is available is not representative of the universe of languages. Thus, some genera or families might be over or under-represented and drive the results. Moreover, if language structures originated in the proto-languages that generated the different families, and are, thus, shared within language families, then languages within a language family might not contribute real independent information. Reassuringly though, this last concern has been, at least partially, addressed by (i) clustering at the family level to account for the lack of independence across observations (Table 2) and (ii) accounting for other geographical characteristics of the Urheimat (Table 4). 
Table 6: Persistent Effect of Urheimat Characteristics: Share of Daughter Languages with Periphrastic Future Tense

\begin{tabular}{|c|c|c|c|c|c|c|}
\hline & \multicolumn{6}{|c|}{ Share of Daughter Languages with Periphrastic Future Tense } \\
\hline & (1) & $(2)$ & $(3)$ & $(4)$ & $(5)$ & (6) \\
\hline Crop Return (pre-1500CE) & $\begin{array}{l}0.19 * * \\
(0.06)\end{array}$ & $\begin{array}{l}0.25^{* * *} \\
(0.04)\end{array}$ & $\begin{array}{l}0.25^{* * *} \\
(0.05)\end{array}$ & $\begin{array}{l}0.24^{* * *} \\
(0.05)\end{array}$ & $\begin{array}{l}0.20^{* * *} \\
(0.05)\end{array}$ & $\begin{array}{l}0.23^{* * *} \\
(0.06)\end{array}$ \\
\hline Regional FE & No & Yes & Yes & Yes & Yes & Yes \\
\hline Main Geographical Controls & No & No & Yes & Yes & Yes & Yes \\
\hline Precipitation Controls & No & No & No & Yes & Yes & Yes \\
\hline Temperature Controls & No & No & No & No & Yes & Yes \\
\hline Unproductive Period & No & No & No & No & No & Yes \\
\hline Observations & 74 & 74 & 74 & 74 & 74 & 74 \\
\hline
\end{tabular}

The analysis further addresses these potential concerns in two ways. First, it explores the relation between the crop return in a language family's Urheimat and the share of daughter languages that have a periphrastic future tense. In particular, the theory suggests that if language structures started forming in the proto-language, crop return in the Urheimat should have a persistent effect on the share of languages with periphrastic future tense within a language family. Table 6 establishes the robust positive statistically and economically significant relation between the Urheimat's crop return and the share of daughter languages that have a periphrastic future tense. The coefficients in the table are the average marginal effects of increasing crop return in the Urheimat in a zero-inflated fractional regression where observations are weighted to account for missing language data within the family. ${ }^{20}$ The estimates imply that a one standard deviation increase in the Urheimat's crop return is associated with an increase of 23 percentage points in the share of daughter languages that have a future tense. Figure 6 depicts the association in an OLS regression that accounts for the same controls as column (6).

Second, in order to account for a potential mismeasurement in the data, due to either mismeasurement of the existence of periphrastic future tense in a daughter language or the location of the Urheimat, the research additionally replicates the analysis using various strategies. In particular, if language structures had developed in the proto-languages and never changed after that, all daughter languages ought to share the same language structures. Thus, any within-family variation would be generated by mismeasurement of the structure of the future tense. In order to address this potential concern, Tables A.3 and A.4 replicate the analysis assuming that the proto-language of each family had periphrastic future tense if the majority of contemporary languages in the family have periphrastic future tense. These tables establish that the probability of a proto-language having periphrastic future tense is increasing in the crop return in its Urheimat.

\footnotetext{
${ }^{20}$ Table A.2 establishes that similar results are obtained if observations are not weighted.
} 


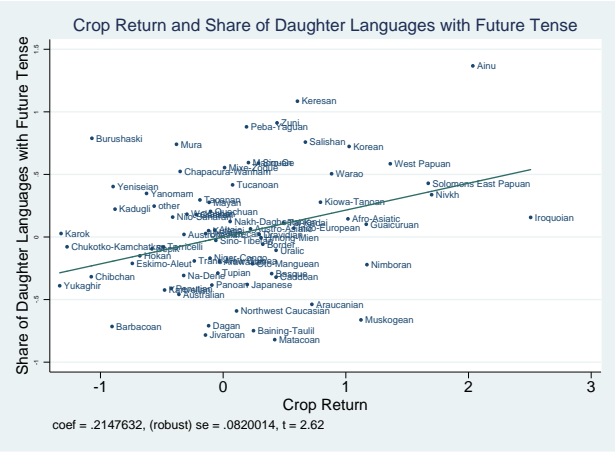

Figure 6: Persistent Effect of Urheimat's Crop Return Share of Daughter Languages with Periphrastic Future Tense

As an additional strategy to address these potential concerns, the analysis explores the relation between crop return and periphrastic future tense at the language family and genus levels. In particular, Tables A.5 and A.6 analyze the relation between pre-1500CE crop return and periphrastic future at the language family level, where the family level values are given by the mean and median value, respectively, within each language family. Reassuringly, the results remain qualitatively unchanged and imply that a one standard deviation increase in crop return is associated with a 44 percentage points increase in the share of daughter languages with a future tense. Alternatively, the results imply a 43 percentage points increase in the probability a proto-language has periphrastic future tense. Moreover, similar results are obtained at the language genus level (Tables A.7 and A.8).

Although reassuring, these results may still be biased if the proto-language is not well approximated by the mean or median of the languages in the family. Thus, as an additional approach, the analysis uses individual languages in the family to approximate the proto-language. In particular, Table A.11 shows the average estimated association between crop return and periphrastic future tense obtained in 5000 simulations, where in each simulation the sample of language families is generated by selecting randomly one language within each family. Again the results suggest an economically and statistically significant positive association between pre-1500CE crop return and the existence of periphrastic future tense. Moreover, similar results are obtained if only geography is sampled, while existence of a future tense is assumed to be given by the language family's median (Table A.12).

\subsubsection{Mechanisms}

This section presents additional supportive evidence for the hypothesized geographical origins of the structure of the future tense. In view of the evidence about the effect of crop return on long-term orientation (Galor and Özak, 2016), the positive effect of crop return on the emergence of periphrastic future tense would necessitate the use of agriculture as the main source of subsistence. In particular, as illustrated in Figure 7, the validity of the proposed hypothesis would imply that: (i) higher crop return ought to be associated with a greater intensity of agriculture, and (ii) greater intensity of agriculture ought to be associated with the existence of periphrastic future tense.

Table 7 presents supporting evidence for the proposed mechanism in Figure 7. In particular, it 


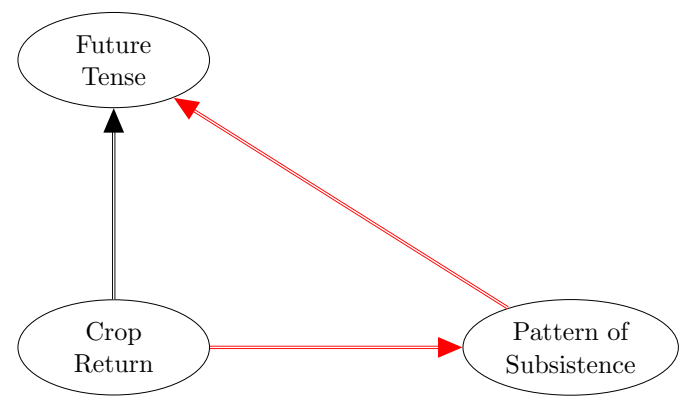

Figure 7: Mechanism: Crop Return \& Pattern of Subsistence

establishes the robust positive association between crop return and the pattern of subsistence in a premodern society. In particular, using data from the Ethnographic Atlas (Murdock and White, 1969) on the importance of patterns of subsistence - hunting, gathering, fishing, animal husbandry and crop cultivation - the analysis explores the effect of crop return on a pre-modern society's agricultural intensity, i.e., the level of dependence on agriculture. Columns (1) and (2) explore the relation for all societies in the Ethnographic Atlas, while columns (3) and (4) constrain the analysis to the set of societies that speak languages for which data on the existence of periphrastic future tense is available. In line with the proposed theory, the results suggest that societies inhabiting regions with higher crop return have higher levels of agricultural intensity. In particular, the results imply that a one-standard deviation increase in crop return is associated with a 0.3 standard deviations increase in agricultural intensity.

Table 7: Agricultural Intensity and Crop Return

\begin{tabular}{|c|c|c|c|c|}
\hline & \multicolumn{4}{|c|}{ Agricultural Intensity } \\
\hline & \multicolumn{2}{|c|}{ Full Sample } & \multicolumn{2}{|c|}{ Future Sample } \\
\hline & (1) & $(2)$ & (3) & (4) \\
\hline Crop Return (pre-1500CE) & $\begin{array}{l}0.19^{* * *} \\
(0.03)\end{array}$ & $\begin{array}{l}0.22^{* * *} \\
(0.02)\end{array}$ & $\begin{array}{l}0.27^{* * *} \\
(0.07)\end{array}$ & $\begin{array}{l}0.30^{* * *} \\
(0.06)\end{array}$ \\
\hline Regional FE & No & Yes & No & Yes \\
\hline All Geographical Controls & No & Yes & No & Yes \\
\hline Adjusted- $R^{2}$ & 0.04 & 0.64 & 0.07 & 0.61 \\
\hline Observations & 1306 & 1306 & 264 & 264 \\
\hline \multicolumn{5}{|c|}{$\begin{array}{l}\text { Notes: This table establishes the positive statistically and economically significant } \\
\text { effect of a language homeland's crop return on the level of agricultural intensity of } \\
\text { a pre-modern society that speaks that language. Standardized coefficients. Het- } \\
\text { eroskedasticity robust standard error estimates are reported in parentheses; *** de- } \\
\text { notes statistical significance at the } 1 \% \text { level, ** at the } 5 \% \text { level, and * at the } 10 \% \\
\text { level, all for two-sided hypothesis tests. }\end{array}$} \\
\hline
\end{tabular}

Second, Table 8 establishes the robust positive association between the level of agricultural intensity in a pre-modern society and the probability of existence of periphrastic future tense in the language it speaks. The results suggest that a one standard deviation increase in agricultural intensity is associated with a 10 percentage point increase in the probability of existence of periphrastic future tense in the society's language. Although these results cannot be given a causal interpretation, they 
are in line with the proposed mechanism in Figure 7. Moreover, if the depicted causal graph were satisfied, i.e., crop return did not affect the existence of a future tense through any other channels, then it would be a valid instrument for agricultural intensity. In fact, Table A.13 replicates the analysis of Table 8 using OLS and also instrumenting agricultural suitability with crop return and the length of the unproductive period, both of which affect a society's agricultural intensity. Reassuringly, the OLS estimates are similar to the Probit ones, while the IV estimates are 3.4 times larger, suggesting that a one standard deviation increase in agricultural suitability would increase the probability of the existence of a future tense by 0.34 percentage points. While this hints that the estimates in Table 8 might be biased towards zero, the overidentification test in Table A.13 suggests that the IV does not satisfy the exclusion restriction.

Table 8: Agricultural Intensity and Existence of Periphrastic Future Tense

\begin{tabular}{llllll}
\hline \hline & \multicolumn{5}{c}{ Existence of Periphrastic Future Tense } \\
\cline { 2 - 6 } & \multicolumn{1}{c}{$(1)$} & $(2)$ & $(3)$ & $(4)$ & $(5)$ \\
\hline Agricultural Intensity & $0.07^{* *}$ & $0.10^{* * *}$ & $0.10^{* *}$ & $0.09^{* *}$ & $0.10^{* *}$ \\
& $(0.03)$ & $(0.04)$ & $(0.04)$ & $(0.04)$ & $(0.04)$ \\
\hline Continental FE & No & Yes & Yes & Yes & Yes \\
Main Geographic Controls & No & No & Yes & Yes & Yes \\
Main Precipitation Controls & No & No & No & Yes & Yes \\
Main Temperature Controls & No & No & No & No & Yes \\
Pseudo- $R^{2}$ & 0.02 & 0.07 & 0.09 & 0.10 & 0.16 \\
Observations & 264 & 264 & 264 & 264 & 264 \\
\hline
\end{tabular}

Notes: This table establishes the positive statistically and economically significant effect of the level of agricultural intensity of a pre-modern society on the existence of a future tense in the language spoken by the society. Standardized coefficients. Heteroskedasticity robust standard error estimates are reported in parentheses; *** denotes statistical significance at the $1 \%$ level, $* *$ at the $5 \%$ level, and $*$ at the $10 \%$ level, all for two-sided hypothesis tests.

\subsubsection{Crop Return, Long-Term Orientation and Periphrastic Future Tense}

This section analyzes the empirical relation between the share of speakers of languages with periphrastic future tense and long-term orientation across countries in the contemporary era. In particular, the previous sections have provided historical evidence that the same forces that gave rise to long-term orientation also affected the existence of a future tense. But, if as proposed by the theory, language structures encode cultural traits and have a persistent effect on economic development, then one should expect individual's long-term orientation to be associated with the existence of periphrastic future tense in the language they speak.

In order to explore this association, the analysis uses two measures of long-term orientation at the country level. In particular, it examines the effect of the existence of periphrastic future tense on the cultural dimension identified by Hofstede et al. (2010) as Long-Term Orientation (LTO) as depicted in Figure $8 .{ }^{21}$ Additionally, it uses a measure of LTO based on the share of individuals in a country that

\footnotetext{
${ }^{21}$ Hofstede et al. (2010) define Long-Term Orientation as the cultural value that stands for the fostering of virtues oriented toward future rewards, perseverance and thrift. Hofstede et al. (2010) constructed their data based on interviews
} 


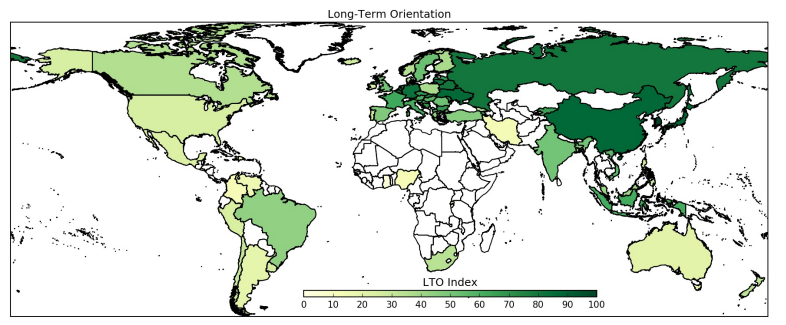

(a) Long-Term Orientation

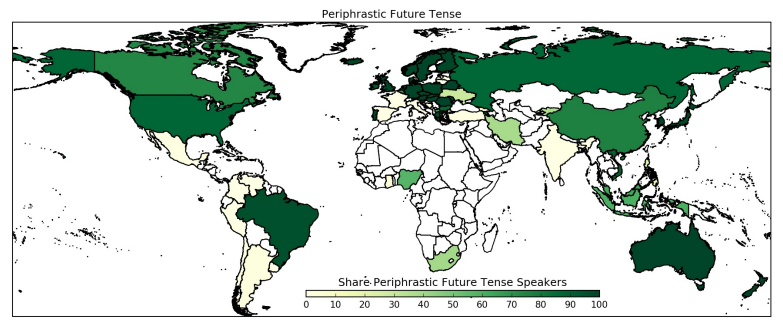

(b) Periphrastic Future Tense

Figure 8: Long-Term Orientation and Periphrastic Future Tense

reported having LTO in the WVS. ${ }^{22}$ In order to explore the relation between the share of speakers of languages with a future tense and Long-Term Orientation, the following empirical specification is estimated via ordinary least squares (OLS):

$$
L T O_{i}=\beta_{0}+\beta_{1} \text { Future }_{i}+\beta_{2} \text { Crop Return } i+\sum_{j} \gamma_{0 j} X_{i j}+\sum_{c} \gamma_{c} \delta_{c}+\epsilon_{i}
$$

where $L T O_{i}$ is the level of Long-Term Orientation in country $i$, Future $i$ is the share of speakers of languages with periphrastic future tense in country $i,{ }^{23}$ Crop Return ${ }_{i}$ is the pre-1500CE crop return of country $i,\left\{X_{i j}\right\}_{j}$ is a set of geographical characteristics of country $i,\left\{\delta_{c}\right\}$ is a complete set of regional fixed-effects, and $\epsilon_{i}$ is the error term of country $i$. The results of the previous section suggest that one should expect $\beta_{1}>0$ and $\beta_{2}>0$.

Table 9 presents the results of this analysis. In particular, column (1) shows the positive unconditional correlation between the share of speakers of languages with periphrastic future tense and LTO (Hofstede et al., 2010). The coefficient is statistically significant at the $1 \%$ and suggests that a one standard deviation increase in a country's share of population who speak a language with periphrastic future tense is associated with a 0.32 standard deviation increase in LTO. Column (2) additionally accounts for the pre-1500CE crop return to which ancestors of the current population of the country had been exposed to (Galor and Özak, 2016). Reassuringly, both the share of speakers of languages with periphrastic future tense and pre- $1500 \mathrm{CE}$ crop return are significant at the $1 \%$, and their signs follow the pattern suggested by the theory and the historical evidence of previous sections. In particular, the coefficient on periphrastic future tense is positive, and its magnitude is hardly affected by the inclusion of pre-1500 crop return into the analysis. On the other hand, the coefficient on pre$1500 \mathrm{CE}$ crop return is positive and significant, suggesting that a one standard deviation increase in

of IBM employees across the world, and later expanded it using the data from the Chinese Values Survey and from the World Values Survey. The Long-Term Orientation (LTO) measure varies between 0 (short-term orientation) and 100 (long-term orientation). This measure is positively correlated with the importance ascribed future profits, savings rates, investment in real estate, and math and science scores (Hofstede et al., 2010).

${ }^{22}$ The measure of Long-Term Orientation is based on the following question in the WVS: "Here is a list of qualities that children can be encouraged to learn at home. Which, if any, do you consider to be especially important?" Individuals are considered to have Long-Term Orientation if they answered "Thrift, saving money and things".

${ }^{23}$ The share of speakers of languages with periphrastic future tense in country $i$ is determined by the number of speakers of each language according to the Ethnologue. Since there are many languages for which the data on the existence of periphrastic future tense is missing, the analysis is restricted only to countries for which the data available covers at least $50 \%$ of the population. 
Table 9: Long Term Orientation, Pre-1500 Crop Return and Periphrastic Future Tense

\begin{tabular}{llllll}
\hline \hline & \multicolumn{4}{c}{ Long Term Orientation } \\
\cline { 2 - 5 } & \multicolumn{4}{c}{ Hofstede } & \multicolumn{1}{c}{ WVS } \\
\cline { 2 - 5 } \cline { 3 - 5 } & \multicolumn{1}{c}{$(1)$} & $(2)$ & $(3)$ & $(4)$ & $(5)$ \\
\hline Periphrastic Future Tense & $0.35^{* * *}$ & $0.31^{* * *}$ & $0.22^{* *}$ & 0.02 & $0.20^{*}$ \\
& $(0.11)$ & $(0.09)$ & $(0.10)$ & $(0.10)$ & $(0.11)$ \\
Crop Return (Pre-1500, Ancestors) & & $0.52^{* * *}$ & $0.49^{* * *}$ & $0.46^{* * *}$ & $0.33^{* *}$ \\
& & $(0.09)$ & $(0.08)$ & $(0.09)$ & $(0.15)$ \\
\hline Main Geographic Controls & No & No & Yes & Yes & Yes \\
Regional FE & No & No & No & Yes & Yes \\
Adjusted- $R^{2}$ & 0.11 & 0.38 & 0.41 & 0.56 & 0.30 \\
Observations & 69 & 69 & 69 & 69 & 76 \\
\hline
\end{tabular}

Notes: This table establishes the positive, statistically and economically significant association between the share of speakers of languages with periphrastic future tense and Long-Term Orientation. The analysis accounts for ancestors exposure to pre-1500CE crop return, regional fixed-effects and geographical characteristics as in previous tables. The analysis uses the measures of Long-term Orientation from Hofstede et al. (2010) and the World Values Survey. Standardized coefficients. Heteroskedasticity robust standard error estimates are reported in parentheses; *** denotes statistical significance at the $1 \%$ level, ** at the $5 \%$ level, and * at the $10 \%$ level, all for two-sided hypothesis tests.

pre-1500CE crop return is associated with 0.54 standard deviation increase in LTO. It is important to highlight that in this analysis, pre-1500CE crop return is associated to the location of the ancestors of populations of contemporary countries, and not with languages' homelands, although in some cases the two might be identical. This allows the analysis to (partially) disentangle the association between these two historical components of LTO.

Column (3) additionally accounts for countries' geographical characteristics (absolute latitude, terrain ruggedness, mean elevation above sea level and coast length) without affecting the qualitative results. Additionally, column (4) accounts for regional time invariant unobserved heterogeneity. While the qualitative effect of pre-1500CE crop return remains unchanged, the coefficient on periphrastic future tense becomes insignificant, reflecting in part the lack of variation in the existence of periphrastic future tense among languages spoken within many regions. E.g., due to their colonial history, most people in Latin America speak Spanish, and thus very little variation in the share of speakers with languages with periphrastic future tense remains in this region. Interestingly, the results in column (5), which replicate the analysis for the WVS measure in a larger sample, suggest that the association between LTO and periphrastic future tense remains significant even when accounting for regional fixed-effects.

These results suggest that periphrastic future tense is associated with long-term orientation. Furthermore, the analysis provides suggestive evidence that periphrastic future tense is associated with long-term orientation in the contemporary era, above and beyond the effect of the crop return experienced by populations' ancestors. In particular, in a country where languages spoken today originated in regions different from the ones where the country's ancestors came from, the established association hints to a potential direct effect of periphrastic future tense on contemporary long-term orientation (and thus potentially on development). 


\subsection{The Origins of Sex-Based Grammatical Gender Systems}

The proposed hypothesis suggests that in a society characterized by distinct gender roles and consequently by the existence of gender bias, sex-based grammatical gender systems that could have fortified the existing social structure and cultural norms may have emerged and persisted over time. Moreover, geographical characteristics that were complementary to the usage of the plow and thus to the emergence of distinct gender roles in society (Pryor, 1985; Alesina et al., 2013), may have fostered the emergence and the prevalence of sex-based grammatical gender.

Table 10: Geographic Origins of Plow Usage and Sex-Based Grammatical Genders

\begin{tabular}{|c|c|c|c|c|c|c|}
\hline & \multirow{2}{*}{\multicolumn{2}{|c|}{$\frac{\text { Reduced Form }}{\text { Grammatical Gender }}$}} & \multicolumn{4}{|c|}{ Mechanism } \\
\hline & & & \multicolumn{2}{|c|}{ Plow Usage } & \multicolumn{2}{|c|}{ Grammatical Gender } \\
\hline & (1) & $(2)$ & $(3)$ & $(4)$ & $(5)$ & (6) \\
\hline Average Caloric Yield (Plow Negative Crops, pre-1500) & $\begin{array}{l}-0.12^{* *} \\
(0.05)\end{array}$ & $\begin{array}{l}-0.20^{* * *} \\
(0.07)\end{array}$ & $\begin{array}{l}-0.25^{* * *} \\
(0.02)\end{array}$ & $\begin{array}{l}-0.06^{* * *} \\
(0.02)\end{array}$ & & \\
\hline Average Caloric Yield (All Crops, pre-1500) & $\begin{array}{l}0.15^{* * *} \\
(0.05)\end{array}$ & $\begin{array}{l}0.21^{* * *} \\
(0.06)\end{array}$ & $\begin{array}{l}0.25^{* * *} \\
(0.02)\end{array}$ & $\begin{array}{l}0.10^{* * *} \\
(0.02)\end{array}$ & & \\
\hline Plow Usage & & & & & $\begin{array}{l}0.37^{* * * *} \\
(0.10)\end{array}$ & $\begin{array}{l}0.20 \\
(0.12)\end{array}$ \\
\hline All Geographic Controls & No & Yes & No & Yes & No & Yes \\
\hline Regional FE & No & Yes & No & Yes & No & Yes \\
\hline Adjusted- $R^{2}$ & 0.03 & 0.21 & 0.20 & 0.47 & 0.13 & 0.28 \\
\hline Observations & 217 & 217 & 1178 & 1178 & 114 & 114 \\
\hline
\end{tabular}

Notes: This table establishes, based on OLS regression, the positive statistically and economically significant effect of the geographical determinants of plow usage on the existence of sex-based grammatical gender in a language. The first two columns provide the results of the reduced form, and columns (3)-(6) provide evidence on the mechanism. Heteroskedasticity robust standard error estimates are reported in parentheses; $* * *$ denotes statistical significance at the $1 \%$ level, ** at the $5 \%$ level, and $*$ at the $10 \%$ level, all for two-sided hypothesis tests.

Table 10 explores the relation between the average potential caloric yield across plow negative crops, the usage of the plow, and the existence of sex-based grammatical genders. Columns (1) and (2) report the unconditional and conditional relation between the complementarity of the geographical environment to the use of the plow and the existence of sex-based grammatical gender. The results suggest a significant negative association between geographical characteristics that are not suitable for the use of the plow and the existence of sex-based grammatical gender. In particular, the estimates suggest that a one standard deviation increase in the average caloric yield across crops that are not suitable for the use of the plow decreases the probability of having a sex-based grammatical gender by 17 percentage points. Columns (3) and (4) report the correlation between the usage of the plow across ethnic groups as reported in the Ethnographic Atlas and its determinants, without any controls and with the main geographical controls and regional fixed-effects. In line with the theory of Pryor (1985) and Alesina et al. (2013) the average potential caloric yield across plow negative crops affects the adoption of the plow. Finally, columns (5) and (6) provide evidence of a positive and marginally significant association between the usage of the plow and the existence of sex-based grammatical gender systems in a language. Thus, as suggested by the proposed hypothesis, sex-based grammatical gender systems and the existence of gender roles in society have common geographical roots. 
Table 11: Persistent Effect of Homeland vs. Urheimat Characteristics on Gender: Languages Outside Urheimat

\begin{tabular}{|c|c|c|c|c|}
\hline & \multicolumn{4}{|c|}{ Existence of Sex-Based Gender System } \\
\hline & \multicolumn{2}{|c|}{ Homeland } & \multicolumn{2}{|c|}{ Urheimat } \\
\hline & (1) & $(2)$ & $(3)$ & $(4)$ \\
\hline Average Caloric Yield (Plow Negative Crops, pre-1500) & $\begin{array}{l}-0.10 \\
(0.12)\end{array}$ & $\begin{array}{l}-0.17 \\
(0.11)\end{array}$ & $\begin{array}{l}0.22 \\
(0.19)\end{array}$ & $\begin{array}{l}-0.42^{* *} \\
(0.17)\end{array}$ \\
\hline Average Caloric Yield (All Crops, pre-1500) & $\begin{array}{l}0.06 \\
(0.11)\end{array}$ & $\begin{array}{l}0.09 \\
(0.08)\end{array}$ & $\begin{array}{l}0.32^{* * *} \\
(0.07)\end{array}$ & $\begin{array}{l}1.07^{* * *} \\
(0.12)\end{array}$ \\
\hline Regional FE & No & Yes & No & Yes \\
\hline Homeland Geographical Characteristics & No & Yes & No & No \\
\hline Urheimat Geographical Characteristics & No & No & No & Yes \\
\hline Adjusted- $R^{2}$ & -0.00 & 0.19 & 0.38 & 0.68 \\
\hline Observations & 100 & 100 & 100 & 100 \\
\hline Language Families & 19 & 19 & 19 & 19 \\
\hline
\end{tabular}

Tables 11 and C.2 further explore the relative contributions of geographical characteristics that are not conducive for the use of the plow in the homeland vs. the Urheimat on the presence of a sex-based grammatical gender system in a daughter language. In particular, Table 11 establishes that the existence of a sex-based grammatical gender system among daughter languages located outside the Urheimat of their proto-language is negatively significantly associated only with average caloric yield across crops that are not suitable for the use of the plow in the Urheimat. Thus, the results further suggest the persistence of deep-historical origins of sex-based grammatical gender systems and their association with plow suitability. In particular, a one standard deviation increase in the average caloric yield across crops that are not suitable for the use of the plow in the Urheimat is associated with 42 percentage points decrease in the probability of existence of a sex-based grammatical system in a daughter language. Importantly, as before, by focusing on languages located outside the Urheimat of their proto-language and accounting for regional fixed-effects, the analysis mirrors the epidemiological approach to cultural diffusion, thus addressing potential concerns regarding omitted variables at the host-region level and providing support to the view that the origins of sex-based grammatical in contemporary languages are found in cultural processes that took place during the formation of protolanguages.

\subsection{The Origins of Politeness Distinctions in Pronouns}

The theory suggests that in a hierarchical society characterized by obedience, conformity, and power distance, language structures that reinforced the existing hierarchical structure and cultural norms were likely to emerge and persist in this unequal society. In particular, politeness distinctions in pronouns (e.g., "tu" and "usted" in Spanish, "Du" and "Sie" in German, and "tu" and "vous" in French) were likely to appear and endure in this hierarchical society. Thus, geographical characteristics 
such as ecological diversity and agricultural suitability, which were conducive to the development of hierarchical societies (Diamond, 1997; Fenske, 2014; Litina, 2014; Depetris-Chauvin and Özak, 2016), would be expected to be associated with the emergence of politeness distinctions as well.

Table 12: Geographic Origins of Politeness Distinctions and Jurisdictional Hierarchy

\begin{tabular}{|c|c|c|c|c|c|c|}
\hline & \multirow{2}{*}{\multicolumn{2}{|c|}{$\begin{array}{c}\text { Reduced Form } \\
\text { Politeness }\end{array}$}} & \multicolumn{4}{|c|}{ Mechanism } \\
\hline & & & \multicolumn{2}{|c|}{$\begin{array}{c}\text { Jurisdictional } \\
\text { Hierarchy }\end{array}$} & \multicolumn{2}{|c|}{ Politeness } \\
\hline & (1) & $(2)$ & $(3)$ & (4) & $(5)$ & (6) \\
\hline Ecological Diversity & $\begin{array}{l}0.14^{* * *} \\
(0.03)\end{array}$ & $\begin{array}{l}0.09^{* *} \\
(0.04)\end{array}$ & $\begin{array}{l}0.17^{* * *} \\
(0.03)\end{array}$ & $\begin{array}{l}0.10^{* * *} \\
(0.03)\end{array}$ & & \\
\hline Average Caloric Yield (All Crops, pre-1500) & $\begin{array}{l}0.11^{* * *} \\
(0.03)\end{array}$ & $\begin{array}{l}0.12^{* * *} \\
(0.03)\end{array}$ & $\begin{array}{l}0.17^{* * *} \\
(0.03)\end{array}$ & $\begin{array}{l}0.23^{* * *} \\
(0.03)\end{array}$ & & \\
\hline Jurisdictional Hierarchy & & & & & $\begin{array}{l}0.23^{* * *} \\
(0.02)\end{array}$ & $\begin{array}{l}0.18^{* * *} \\
(0.04)\end{array}$ \\
\hline All Geographic Controls & No & Yes & No & Yes & No & Yes \\
\hline Regional FE & No & Yes & No & Yes & No & Yes \\
\hline Adjusted- $R^{2}$ & 0.15 & 0.31 & 0.05 & 0.32 & 0.37 & 0.49 \\
\hline Observations & 198 & 198 & 1169 & 1169 & 113 & 113 \\
\hline
\end{tabular}

Table 12 uses a linear probability model (OLS) to explore the relation between ecological diversity, caloric suitability, jurisdictional hierarchy beyond the local level and politeness distinctions. ${ }^{24}$ Columns (1) and (2) present the correlation between ecological diversity, caloric suitability and politeness distinctions. The relations are positive and economically and statistically significant, suggesting in particular that a one standard deviation increase in ecological diversity increases the probability of having politeness distinctions in the language by 9 percentage points. Columns (3) and (4) report the relation between the level of jurisdictional hierarchy beyond the local level and ecological diversity and caloric suitability. As in Fenske (2014) for ethnic groups in Africa and Depetris-Chauvin and Özak (2016) for ethnic groups in the world as a whole, ecological diversity has a positive statistically and economically significant effect on the emergence of jurisdictional hierarchy beyond the local level. Finally, columns (5) and (6) present the relation between jurisdictional hierarchy beyond the local level and the existence of politeness distinctions. As suggested by the hypothesis, jurisdictional hierarchy has a positive and economically and statistically significant effect at the $1 \%$ level on the emergence of politeness distinctions in a language. These results provide evidence that the origins of politeness distinctions are indeed generated by the same factors as hierarchical societies.

Tables 13 and C.3 further explore the relative contributions of ecological diversity and agricultural suitability in the homeland vs. the Urheimat to the presence of politeness distinctions in a daughter

\footnotetext{
${ }^{24}$ The Ethnographic Atlas reports the level of jurisdictional hierarchy beyond the local level (v33), which captures the level of statehood of an ethnicity.
} 
Table 13: Persistent Effect of Homeland vs. Urheimat Characteristics on Politeness:

Languages Outside Urheimat

\begin{tabular}{|c|c|c|c|c|}
\hline & \multicolumn{4}{|c|}{ Existence Politeness Distinctions } \\
\hline & \multicolumn{2}{|c|}{ Homeland } & \multicolumn{2}{|c|}{ Urheimat } \\
\hline & $(1)$ & $(2)$ & $(3)$ & $(4)$ \\
\hline Ecological Diversity & $\begin{array}{l}0.14^{* * *} \\
(0.03)\end{array}$ & $\begin{array}{l}0.13^{* * *} \\
(0.03)\end{array}$ & $\begin{array}{l}0.04 \\
(0.15)\end{array}$ & $\begin{array}{l}0.35 * * \\
(0.15)\end{array}$ \\
\hline Average Caloric Yield (All Crops, pre-1500) & $\begin{array}{l}0.16^{* * *} \\
(0.05)\end{array}$ & $\begin{array}{l}0.13^{* * *} \\
(0.04)\end{array}$ & $\begin{array}{l}0.18 \\
(0.14)\end{array}$ & $\begin{array}{l}-0.28^{* *} \\
(0.12)\end{array}$ \\
\hline Regional FE & No & Yes & No & Yes \\
\hline Homeland Geographical Characteristics & No & Yes & No & No \\
\hline Urheimat Geographical Characteristics & No & No & No & Yes \\
\hline Adjusted- $R^{2}$ & 0.15 & 0.31 & 0.12 & 0.40 \\
\hline Observations & 116 & 116 & 116 & 116 \\
\hline Language Families & 19 & 19 & 19 & 19 \\
\hline
\end{tabular}

language. In contrast to the previous two language structures, and consistent with evidence about the greater adaptability of politeness distinctions, Table 13 and C.3 suggests that the existence of politeness distinctions among daughter languages is positively significantly associated with ecological diversity and agricultural suitability in their homeland as well as their change in the transition from the Urheimat to the homeland.

\section{Language Structures \& Contemporary Behavior}

This section explores the potential effect of the linguistic channel of cultural transmission on contemporary behavior. The analysis focuses on the effect of (i) the presence periphrastic future tense and its association with long-term orientation on educational attainment, and (ii) the presence of sex-based grammatical gender and its association to gender bias on female educational attainment. ${ }^{25}$

\subsection{Identification Strategy}

As illustrated in Figure 9, the effect of culture on human behavior is rather intricate. Several strategies are employed in order to surmount the significant hurdles in the identification of the effect of languageembodied cultural traits on human behavior, while isolating this effect from the persistent effect of cultural traits via non-linguistic channels.

Following the epidemiological approach for the identification of the persistent effects of cultural traits on human behavior and economic outcomes (Giuliano, 2007; Fernandez and Fogli, 2009; Galor

\footnotetext{
${ }^{25}$ A similar analysis cannot be conducted for politeness distinctions, since the existing individual data, which identify the language spoken by individuals and their ancestry, does not contain individual outcomes that could be linked to politeness distinctions or attitude towards hierarchy.
} 


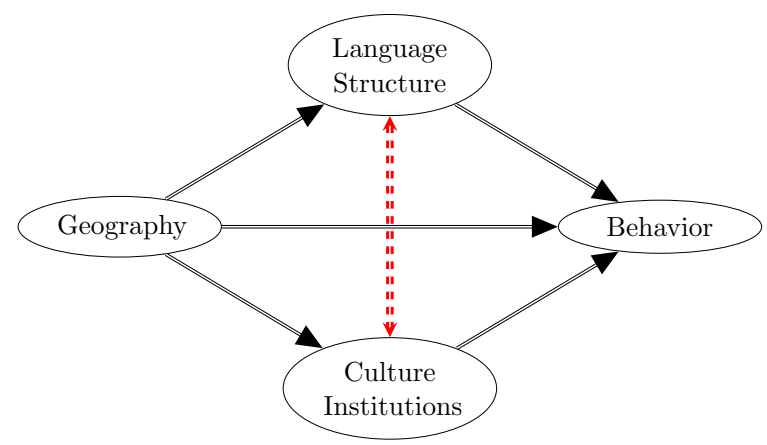

Figure 9: Language and Contemporary Behavior

and Özak, 2016), the research focuses on the behavior of second-generation migrants who share the same country of birth, removing concerns about the role of geographical, institutional and cultural characteristic in this country. Moreover, the analysis accounts for individual characteristics (e.g., age, gender, and marital status), which might affect individual behavior while being correlated with the language spoken by the individual. Finally, it accounts for year and locality fixed-effects, further removing the potentially confounding effects of the period as well as the local geography, culture, institutions, and socio-economic environment.

Nevertheless, the traditional epidemiological approach cannot fully distinguish between the persistent effect of observed cultural characteristics and omitted ancestral characteristics at the parental countries of origin. In particular, since the basic premise of the epidemiological approach is that second-generation migrants from the same parental countries of origin share the cultural heritage of those countries, the traditional epidemiological approach cannot account for parental countries of origin fixed-effects. In contrast, in light of the fact that second-generation migrants that have identical parental countries of origin may speak different languages, one can isolate the effect of languageembodied cultural traits on human behavior, by accounting for parental countries of origin fixed-effects (i.e., common ancestral factors such as geographical, institutional and cultural characteristics that may affect individual behavior).

Hence, the analysis exploits variations in language structures across individuals that are originated from the same ancestral homelands in order to identify the effect of language-embodied cultural traits on human behavior, while also accounting for confounding parental characteristics such as education and the level of proficiency in the local language.

\subsection{Crop Return, Periphrastic Future Tense, and Long-Term Oriented Behavior of Second-Generation Migrants}

This section explores the language-embodied effect of long-term orientation, as reflected in periphrastic future tense, on the long-term oriented behavior of its speakers as opposed to the persistent effect of cultural traits via non-linguistic channels. ${ }^{26}$ Given the data requirements for the identification strategy discussed in the previous section, the analysis focuses on the effect of periphrastic future tense on

\footnotetext{
${ }^{26}$ The effect of long-term orientation on human capital accumulation via non-linguistic channels is studied by Galor and Özak (2016) and Figlio et al. (2016).
} 
human capital accumulation of second-generation migrants in the US. In particular, it explores the effect of speaking a language with periphrastic future tense on the probability of college attendance of these second-generation migrants. ${ }^{27,28}$

In order to analyze the effect of periphrastic future tense on college attendance, the following general specification is estimated via ordinary least squares (OLS):

$$
\text { College }_{i s t l p}=\beta_{0}+\beta_{1} \text { Future }_{i s t l p}+\beta_{2} \operatorname{Return}_{i s t l p}+\sum_{j} \gamma_{0 j} X_{i s t l p j}+\sum_{s t p j} \gamma_{s t p j} \delta_{s t p j}+\epsilon_{i s t l p}
$$

where College $\mathrm{e}_{i s t p}$ indicates whether individual $i$ in state $s$ in period $t$ who speaks language $l$ with parental ancestry $p$ has attended college or not, Future ${ }_{i s t l p}$ indicates the existence of periphrastic future tense in language $l$ spoken by the individual, the Return ${ }_{i s t l p}$ is the pre-1500CE crop return in the homeland of language $l$ spoken by the individual, $\left\{X_{i s t l p j}\right\}_{j}$ is a set of additional geographical characteristics of the homeland of the language spoken by the individual, $\left\{\delta_{s t p j}\right\}_{j}$ is a set of fixedeffects that account jointly for individual characteristics $j$ (sex, age, marital status), state $s$, year $t$, and parental ancestry $p$, and $\epsilon_{i s t l}$ is the error term. Thus, the fixed-effects ensure that only individuals that are similar in their observable individual characteristics, their location and ancestry are compared to each other. The results on the origins of the periphrastic future tense presented in the historical analysis in section 3.2 suggest that future tense and pre-1500 crop return should have a positive effect on college attendance (i.e. $\beta_{1}>0$ and $\beta_{2}>0$ ).

Table 14 establishes the positive effect of speaking a language with periphrastic future tense on college attendance of its speakers. In particular, columns (1)-(3) show that individuals who speak a language with periphrastic future tense have 20 percentage points higher probability of attending college than individuals with similar observable characteristics living in the same state and interviewed the same year, who do not speak a language with periphrastic future tense, even after accounting geographical characteristics of the homeland of the language.

As mentioned in the identification strategy, one potential concern with the results of columns (1)-(3) is that the estimated effect of language also captures additional cultural elements due to the ancestry of the individual. In order to overcome this potential concern, column (4) additionally accounts for the parental country of origin. Thus, the estimated effect of periphrastic future tense in column (4) captures the effect of language that is not explained by other ancestral traits, and therefore isolates

\footnotetext{
${ }^{27}$ Data is taken from the US Census and American Community Survey for the years post-2000 based on IPUMS (Ruggles et al., 2015). Second-generation migrants include all US-born individuals with at least one foreign born parent. The data on second generation migrants include 165250 offsprings of parents who migrated to the United States from 138 different countries - 137 countries of origin of the mother and 136 countries of origin of the father; these individuals speak 62 different languages. The sample of second-generation migrants in the US is constrained to include only individuals over 24 years of age in order to ensure they are old enough to have attended college. As shown in the appendix, similar results are obtained if the age is constrained to be over 21 or 18.

${ }^{28}$ By focusing on second-generation migrants in the US Census and American Community Surveys (ACS), the analysis overcomes a potential concern due to ethnic attrition bias (Duncan and Trejo, 2016). In particular, previous analyses that have employed the US census or ACS to study the effects of culture using migrants, have focused on all US-born individuals and tried to identify migrants and their ancestry by using individual's self-reported ancestry. Thus, these analyses have included all descendants of migrants that still identify with the country of origin of their ancestors. But, as Duncan and Trejo (2011, 2016), among others, have shown, individuals tend to self-identify differently depending on their generation, their true ancestry, and their socio-economic background. Thus, using second-and-higher-generation migrants can bias the results due to misidentification of ancestry.
} 
Table 14: Periphrastic Future Tense and College Attendance of Second-Generation Migrants

\begin{tabular}{|c|c|c|c|c|c|c|}
\hline & \multicolumn{6}{|c|}{ College Attendance } \\
\hline & $(1)$ & $(2)$ & $(3)$ & $(4)$ & $(5)$ & $(6)$ \\
\hline Periphrastic Future Tense & $\begin{array}{l}0.201^{* * *} \\
(0.013)\end{array}$ & $\begin{array}{l}0.207^{* * *} \\
(0.007)\end{array}$ & $\begin{array}{l}0.201^{* * *} \\
(0.007)\end{array}$ & $\begin{array}{l}0.046^{* * *} \\
(0.011)\end{array}$ & & $\begin{array}{l}0.041^{* * *} \\
(0.012)\end{array}$ \\
\hline Crop Return (pre-1500CE) (mean) & & & & & $\begin{array}{l}0.013^{* * *} \\
(0.004)\end{array}$ & $\begin{array}{l}0.007^{*} \\
(0.004)\end{array}$ \\
\hline Main Geographical Controls & Yes & Yes & Yes & Yes & Yes & Yes \\
\hline State FE & Yes & Yes & Yes & Yes & Yes & Yes \\
\hline Year FE & Yes & Yes & Yes & Yes & Yes & Yes \\
\hline Age FE & No & Yes & Yes & Yes & Yes & Yes \\
\hline Gender FE & No & Yes & Yes & Yes & Yes & Yes \\
\hline Marital Status FE & No & No & Yes & Yes & Yes & Yes \\
\hline Parental Origin FE & No & No & No & Yes & Yes & Yes \\
\hline Adjusted- $R^{2}$ & 0.05 & 0.07 & 0.08 & 0.13 & 0.13 & 0.13 \\
\hline$R^{2}$ & 0.05 & 0.11 & 0.17 & 0.45 & 0.45 & 0.45 \\
\hline Observations & 165250 & 165250 & 165250 & 165250 & 165250 & 165250 \\
\hline
\end{tabular}

the effect of long-term orientation that is language-embodied from the persistent cultural effects of long-term orientation via non-linguistic channels. The results suggest that speaking a language with periphrastic future tense increases the probability of attending college by 4.6 percentage points.

Additionally, Column (5) establishes that the pre-1500 crop return in a language's homeland has a positive effect on the accumulation of human capital of its speakers, even after accounting for all other ancestral characteristics of an individual and other geographical characteristics of the language's homeland. Column (6) provides supportive evidence to the view that periphrastic future tense reflected the cultural effect of crop return. In particular, it suggests that the effect of crop return is mediated by a language's periphrastic future tense. Thus, columns (5) and (6) support the view that the effect of periphrastic future tense partly captures the persistent effect of cultural traits that reflect crop return and thus long-term orientation.

There are various potential concerns with the results of Table 14. First, second-generation migrants in the US Census and ACS can only be identified for individuals who live with their parents. Although this is a representative sample of this subpopulation, which overcomes concerns due to ethnic attrition (see footnote 28) and allows for the control of parental characteristics in the analysis, it might potentially bias the results. Appendix B.8 explores the differences in observables between various samples of migrants. Reassuringly, it shows that only age and marital status differ between the full sample of second-generation migrants and the subsample that lives with their parents. Moreover, the sample of second-and-higher generation migrants, that has previously been employed in the literature, and which is subject to ethnic attrition bias, is more similar to the true third-and-higher-generation migrant sample.

In order to assess the potential bias due to the sample, Table B.1 replicates the basic results 
(without ancestry fixed-effects given the potential for ethnic attrition bias) for the sample of secondand-higher generation migrants. Additionally, Table B.2 replicates the analysis in Table 14 using the sample of one-and-a-half-generation migrants, i.e., migrants who were born in another country, but arrived to the US before age 5 . The benefits of using this sample is that (i) it has similar properties for cultural analysis as second-generation migrants, and (ii) it overcomes the potential concerns due to both ethnic attrition and living arrangements. ${ }^{29}$ Reassuringly, the qualitative results remain unchanged and suggest that speaking a language with periphrastic future tense increases the probability of college attendance by 5 percentage points, above and beyond the effect of other ancestral traits.

Table 15: Periphrastic Future Tense and College Education of Second Generation Migrants Accounting for Parental Education and English Levels

\begin{tabular}{|c|c|c|c|c|c|c|c|c|c|}
\hline & \multicolumn{9}{|c|}{ College Attendance } \\
\hline & \multicolumn{3}{|c|}{ Parental Education } & \multicolumn{3}{|c|}{ Parental English } & \multicolumn{3}{|c|}{ Both } \\
\hline & $(1)$ & $(2)$ & $(3)$ & $(4)$ & $(5)$ & (6) & $(7)$ & $(8)$ & $(9)$ \\
\hline Periphrastic Future Tense & $\begin{array}{l}0.047^{* * *} \\
(0.007)\end{array}$ & & $\begin{array}{l}0.043^{* * *} \\
(0.007)\end{array}$ & $\begin{array}{l}0.038 * * * \\
(0.008)\end{array}$ & & $\begin{array}{l}0.038^{* * *} \\
(0.009)\end{array}$ & $\begin{array}{l}0.035^{* * *} \\
(0.008)\end{array}$ & & $\begin{array}{l}0.034^{* * *} \\
(0.009)\end{array}$ \\
\hline Crop Return (pre-1500CE) & & $\begin{array}{l}0.013^{* * *} \\
(0.003)\end{array}$ & $\begin{array}{l}0.007^{* * *} \\
(0.003)\end{array}$ & & $\begin{array}{l}0.005 \\
(0.003)\end{array}$ & $\begin{array}{l}0.000 \\
(0.003)\end{array}$ & & $\begin{array}{l}0.006^{* *} \\
(0.003)\end{array}$ & $\begin{array}{l}0.003 \\
(0.003)\end{array}$ \\
\hline Mom's College Attendance & $\begin{array}{l}0.130 * * * \\
(0.003)\end{array}$ & $\begin{array}{l}0.130^{* * *} \\
(0.003)\end{array}$ & $\begin{array}{l}0.130^{* * *} \\
(0.003)\end{array}$ & & & & $\begin{array}{l}0.134^{* * *} \\
(0.004)\end{array}$ & $\begin{array}{l}0.134^{* * *} \\
(0.004)\end{array}$ & $\begin{array}{l}0.134^{* * *} \\
(0.004)\end{array}$ \\
\hline Dad's College Attendance & $\begin{array}{l}0.073^{* * *} \\
(0.003)\end{array}$ & $\begin{array}{l}0.073^{* * *} \\
(0.003)\end{array}$ & $\begin{array}{l}0.073^{* * *} \\
(0.003)\end{array}$ & & & & $\begin{array}{l}0.146^{* * *} \\
(0.004)\end{array}$ & $\begin{array}{l}0.147^{* * *} \\
(0.004)\end{array}$ & $\begin{array}{l}0.146^{* * *} \\
(0.004)\end{array}$ \\
\hline Mom's English Level & & & & $\begin{array}{l}0.012^{* * *} \\
(0.001)\end{array}$ & $\begin{array}{l}0.012^{* * *} \\
(0.001)\end{array}$ & $\begin{array}{l}0.012^{* * *} \\
(0.001)\end{array}$ & $\begin{array}{l}0.013^{* * *} \\
(0.001)\end{array}$ & $\begin{array}{l}0.014^{* * *} \\
(0.001)\end{array}$ & $\begin{array}{l}0.013^{* * *} \\
(0.001)\end{array}$ \\
\hline Dad's English Level & & & & $\begin{array}{l}-0.001 \\
(0.002)\end{array}$ & $\begin{array}{l}-0.001 \\
(0.002)\end{array}$ & $\begin{array}{l}-0.001 \\
(0.002)\end{array}$ & $\begin{array}{l}0.006^{* * *} \\
(0.002)\end{array}$ & $\begin{array}{l}0.006 * * * \\
(0.002)\end{array}$ & $\begin{array}{l}0.006^{* * *} \\
(0.002)\end{array}$ \\
\hline Main Geographical Controls & Yes & Yes & Yes & Yes & Yes & Yes & Yes & Yes & Yes \\
\hline Origin FE for Both Parents & Yes & Yes & Yes & Yes & Yes & Yes & Yes & Yes & Yes \\
\hline State FE & Yes & Yes & Yes & Yes & Yes & Yes & Yes & Yes & Yes \\
\hline Year FE & Yes & Yes & Yes & Yes & Yes & Yes & Yes & Yes & Yes \\
\hline Age FE & Yes & Yes & Yes & Yes & Yes & Yes & Yes & Yes & Yes \\
\hline Gender FE & Yes & Yes & Yes & Yes & Yes & Yes & Yes & Yes & Yes \\
\hline Marital Status FE & Yes & Yes & Yes & Yes & Yes & Yes & Yes & Yes & Yes \\
\hline Adjusted- $R^{2}$ & 0.14 & 0.14 & 0.14 & 0.14 & 0.14 & 0.14 & 0.18 & 0.18 & 0.18 \\
\hline$R^{2}$ & 0.23 & 0.23 & 0.23 & 0.23 & 0.23 & 0.23 & 0.26 & 0.26 & 0.26 \\
\hline Observations & 165250 & 165250 & 165250 & 98623 & 98623 & 98623 & 98623 & 98623 & 98623 \\
\hline
\end{tabular}

Notes: This table establishes the robustness of the positive effect of periphrastic future tense on college attendance to the inclusion of parental educational and English levels. Heteroskedasticity robust standard error estimates clustered at the level of the included fixed-effects are reported in parentheses; *** denotes statistical significance at the $1 \%$ level, ** at the $5 \%$ level, and * at the $10 \%$ level, all for two-sided hypothesis tests.

Second, individuals' education levels are potentially determined by the education level of their parents. Similarly, parents' command of the English language, which is the official language in the US, might potentially affect individual's education levels as well as the language spoken at home.

\footnotetext{
${ }^{29}$ The sample of the one-and-a-half-generation migrants includes 422081 individuals who migrated from 141 different countries to the United States when they were five years old or younger and speak 64 different languages. One-and-ahalf-generation migrants are similar to second-generation migrants, since they were not the ones who made the decision to migrate and grew up in the US, so that they received their K-12 education in the United States.
} 
Table 15 explores the effect of accounting for parents' education levels and their command of the English language. Additionally, the analysis accounts now for fixed-effects for both parents' countries of origin. Reassuringly, the results of Table 14 remain qualitatively unchanged. In particular, the effect of speaking a language with periphrastic future tense remains positive and significant. Additionally, parental education and English levels have a positive effect on their offspring's college attendance, suggesting that college educated parents who have a good command of English have a higher probability of having their children attend college. The estimates suggest that speaking a language with periphrastic future tense has an effect that is about a third of the effect of having a college educated mother or above half the effect of having a college educated father.

Table 16: Periphrastic Future Tense and College Education of Second Generation Migrants Accounting for other Linguistic Structures

\begin{tabular}{|c|c|c|c|c|c|c|c|}
\hline & \multicolumn{7}{|c|}{ College Attendance } \\
\hline & $(1)$ & $(2)$ & $(3)$ & $(4)$ & $(5)$ & $(6)$ & $(7)$ \\
\hline Periphrastic Future Tense & $\begin{array}{l}0.043^{* * *} \\
(0.007)\end{array}$ & $\begin{array}{l}0.049^{* * *} \\
(0.008)\end{array}$ & $\begin{array}{l}0.041^{* * *} \\
(0.008)\end{array}$ & $\begin{array}{l}0.041^{* * *} \\
(0.014)\end{array}$ & $\begin{array}{l}0.045^{* * *} \\
(0.008)\end{array}$ & $\begin{array}{l}0.047^{* * *} \\
(0.008)\end{array}$ & $\begin{array}{l}0.048^{* * *} \\
(0.008)\end{array}$ \\
\hline Crop Return (pre-1500CE) & $\begin{array}{l}0.007^{* * *} \\
(0.003)\end{array}$ & $\begin{array}{l}0.012^{* * *} \\
(0.003)\end{array}$ & $\begin{array}{l}0.011^{* * *} \\
(0.003)\end{array}$ & $\begin{array}{l}-0.004 \\
(0.004)\end{array}$ & $\begin{array}{l}0.010^{* *} \\
(0.004)\end{array}$ & $\begin{array}{l}0.015^{* * *} \\
(0.004)\end{array}$ & $\begin{array}{l}0.014^{* * *} \\
(0.003)\end{array}$ \\
\hline Mom's College Attendance & $\begin{array}{l}0.130 * * * \\
(0.003)\end{array}$ & $\begin{array}{l}0.131^{* * *} \\
(0.003)\end{array}$ & $\begin{array}{l}0.131^{* * *} \\
(0.003)\end{array}$ & $\begin{array}{l}0.133^{* * *} \\
(0.003)\end{array}$ & $\begin{array}{l}0.132^{* * *} \\
(0.003)\end{array}$ & $\begin{array}{l}0.132^{* * *} \\
(0.003)\end{array}$ & $\begin{array}{l}0.132^{* * *} \\
(0.003)\end{array}$ \\
\hline Dad's College Attendance & $\begin{array}{l}0.073^{* * *} \\
(0.003)\end{array}$ & $\begin{array}{l}0.075^{* * *} \\
(0.003)\end{array}$ & $\begin{array}{l}0.075^{* * *} \\
(0.003)\end{array}$ & $\begin{array}{l}0.076^{* * *} \\
(0.003)\end{array}$ & $\begin{array}{l}0.076^{* * *} \\
(0.003)\end{array}$ & $\begin{array}{l}0.075^{* * *} \\
(0.003)\end{array}$ & $\begin{array}{l}0.075^{* * *} \\
(0.003)\end{array}$ \\
\hline Past Tense & & $\begin{array}{l}0.015 \\
(0.014)\end{array}$ & & & & & \\
\hline Perfect Tense & & & $\begin{array}{l}-0.011 \\
(0.007)\end{array}$ & & & & \\
\hline Existence of Gender System & & & & $\begin{array}{c}-0.030^{*} \\
(0.018)\end{array}$ & & & \\
\hline Evidentiality & & & & & $\begin{array}{l}0.018^{* *} \\
(0.008)\end{array}$ & & \\
\hline Consonant Inventories & & & & & & $\begin{array}{l}0.001 \\
(0.007)\end{array}$ & \\
\hline Consonant-Vowel Ratio & & & & & & & $\begin{array}{l}0.001 \\
(0.004)\end{array}$ \\
\hline Main Geographical Controls & Yes & Yes & Yes & Yes & Yes & Yes & Yes \\
\hline Origin FE for Both Parents & Yes & Yes & Yes & Yes & Yes & Yes & Yes \\
\hline State FE & Yes & Yes & Yes & Yes & Yes & Yes & Yes \\
\hline Year FE & Yes & Yes & Yes & Yes & Yes & Yes & Yes \\
\hline Age FE & Yes & Yes & Yes & Yes & Yes & Yes & Yes \\
\hline Gender FE & Yes & Yes & Yes & Yes & Yes & Yes & Yes \\
\hline Marital Status FE & Yes & Yes & Yes & Yes & Yes & Yes & Yes \\
\hline Adjusted- $R^{2}$ & 0.14 & 0.14 & 0.14 & 0.14 & 0.14 & 0.14 & 0.14 \\
\hline$R^{2}$ & 0.23 & 0.23 & 0.23 & 0.23 & 0.23 & 0.23 & 0.23 \\
\hline Observations & 165250 & 158239 & 158239 & 153996 & 155905 & 157002 & 157002 \\
\hline
\end{tabular}

Notes: This table establishes the robustness of the positive effect of periphrastic future tense on college attendance to accounting for other language structures. The analysis accounts for parental ancestry fixed-effect, as well as for parental college attendance. Heteroskedasticity robust standard error estimates clustered at the level of the included fixed-effects are reported in parentheses; $* * *$ denotes statistical significance at the $1 \%$ level, $* *$ at the $5 \%$ level, and * at the $10 \%$ level, all for two-sided hypothesis tests.

Third, although the analysis accounts for parental origin fixed-effects and language level geograph- 
ical characteristics as well as additional controls, the effect of periphrastic future tense may reflect the language-embodied effect of other (ancestral) cultural traits associated with an individual's language, which may be unrelated to long-term orientation and its potential reflection in the periphrastic future tense. Table 16 explores this possibility by additionally accounting for other language structures. Reassuringly, the effect of periphrastic future tense is unaffected by the inclusion of these additional language structures, which are mostly insignificant.

Table 17: Periphrastic Future Tense and College Education of Second Generation Migrants Accounting for Local Labor Market Conditions

\begin{tabular}{|c|c|c|c|c|c|c|}
\hline & \multicolumn{6}{|c|}{ College Attendance } \\
\hline & \multicolumn{3}{|c|}{ No English } & \multicolumn{3}{|c|}{ No Spanish } \\
\hline & $(1)$ & $(2)$ & $(3)$ & $(4)$ & $(5)$ & (6) \\
\hline Periphrastic Future Tense & $\begin{array}{l}0.021^{* *} \\
(0.009)\end{array}$ & & $\begin{array}{l}0.022^{* *} \\
(0.009)\end{array}$ & $\begin{array}{l}0.029 * * * \\
(0.006)\end{array}$ & & $\begin{array}{l}0.027^{* * *} \\
(0.006)\end{array}$ \\
\hline Crop Return (pre-1500CE) (mean) & & $\begin{array}{l}0.001 \\
(0.002)\end{array}$ & $\begin{array}{l}-0.001 \\
(0.002)\end{array}$ & & $\begin{array}{l}0.005^{* * *} \\
(0.002)\end{array}$ & $\begin{array}{l}0.002 \\
(0.002)\end{array}$ \\
\hline Mom's College Attendance & $\begin{array}{l}0.114^{* * *} \\
(0.007)\end{array}$ & $\begin{array}{l}0.114^{* * *} \\
(0.007)\end{array}$ & $\begin{array}{l}0.114^{* * *} \\
(0.007)\end{array}$ & $\begin{array}{l}0.124^{* * *} \\
(0.007)\end{array}$ & $\begin{array}{l}0.123^{* * *} \\
(0.007)\end{array}$ & $\begin{array}{l}0.124^{* * *} \\
(0.007)\end{array}$ \\
\hline Dad's College Attendance & $\begin{array}{l}0.135^{* * *} \\
(0.007)\end{array}$ & $\begin{array}{l}0.135^{* * *} \\
(0.007)\end{array}$ & $\begin{array}{l}0.135^{* * *} \\
(0.007)\end{array}$ & $\begin{array}{l}0.131^{* * *} \\
(0.007)\end{array}$ & $\begin{array}{l}0.130^{* * *} \\
(0.007)\end{array}$ & $\begin{array}{l}0.131^{* * *} \\
(0.007)\end{array}$ \\
\hline Main Geographical Controls & Yes & Yes & Yes & Yes & Yes & Yes \\
\hline Origin FE for Both Parents & Yes & Yes & Yes & Yes & Yes & Yes \\
\hline County FE & Yes & Yes & Yes & Yes & Yes & Yes \\
\hline Year FE & Yes & Yes & Yes & Yes & Yes & Yes \\
\hline Age FE & Yes & Yes & Yes & Yes & Yes & Yes \\
\hline Gender FE & Yes & Yes & Yes & Yes & Yes & Yes \\
\hline Marital Status FE & Yes & Yes & Yes & Yes & Yes & Yes \\
\hline Adjusted- $R^{2}$ & 0.19 & 0.19 & 0.19 & 0.19 & 0.19 & 0.19 \\
\hline$R^{2}$ & 0.34 & 0.34 & 0.34 & 0.34 & 0.34 & 0.34 \\
\hline Observations & 52537 & 52537 & 52537 & 55176 & 55176 & 55176 \\
\hline
\end{tabular}

\footnotetext{
Notes: This table establishes the positive significant effect of periphrastic future tense on college attendance excluding English and Spanish speakers. The analysis accounts for parental ancestry fixed-effect, as well as for parental college attendance. Heteroskedasticity robust standard error estimates three-way clustered by state and country of origin of both parents are reported in parentheses; ${ }^{* * *}$ denotes statistical significance at the $1 \%$ level, ${ }^{* *}$ at the $5 \%$ level, and $*$ at the $10 \%$ level, all for two-sided hypothesis tests.
}

Finally, individual's educational choices can be affected by local socio-economic conditions. In particular, local labor market conditions and opportunities might be affected by ethnic networks, racial or ethnic discrimination, among others. The previous results addressed this issue partially by comparing observationally equivalent second-generation migrants within states. Table B.3 further establishes that the results are qualitatively similar if instead within-county level variation is exploited. Moreover, labor market opportunities might be affected by speaking one of the two main languages in the US, namely English and Spanish. Additionally, the recent increase in (Spanish speaking) immigrants from Latin-America, many with lower levels of human capital, may bias the results. Reassuringly, Table 17 establishes that the results remain qualitatively unchanged if English or Spanish speakers are excluded from the analysis.

The previous results suggest that speaking a language with periphrastic future tense directly 
increases the probability of attending college. One potential interpretation of these results is that using the periphrastic future tense in itself affects behavior. On the other hand, it could be capturing within-country of origin variations in time preference. In particular, if parents come from the same country of origin, but differ in their culture and language, the effect of periphrastic future tense might just be capturing these cultural differences. Table B.4 shows the results of splitting the sample of second-generation migrants among those whose parents come from the same country and those whose parents come from different countries. The table establishes that periphrastic future tense has no effect in the sample of individuals whose parents come from the same country. ${ }^{30}$ On the contrary, the effect of periphrastic future tense remains qualitatively unchanged in the sample of migrants whose parents come from different countries. Although this could still capture some within-country of origin variation, it is less probable to do so. While the effect of periphrastic future tense may reflect the (transmitted) long-term orientation of the parent whose language is spoken at home, the analysis cannot refute the presence of a direct effect of this language structure on college attendance.

Table 18: Gender and College Attendance of Female Second Generation Migrants

\begin{tabular}{|c|c|c|c|c|c|}
\hline & \multicolumn{5}{|c|}{ Female College Attendance } \\
\hline & $(1)$ & $(2)$ & $(3)$ & (4) & $(5)$ \\
\hline Existence of Gender System & $\begin{array}{l}-0.228^{* * *} \\
(0.018)\end{array}$ & $\begin{array}{l}-0.024^{* * *} \\
(0.009)\end{array}$ & $\begin{array}{c}-0.017^{*} \\
(0.009)\end{array}$ & $\begin{array}{l}-0.049^{* * *} \\
(0.007)\end{array}$ & $\begin{array}{l}-0.046^{* * *} \\
(0.008)\end{array}$ \\
\hline Average Caloric Yield (Plow Negative Crops, pre-1500) & & & $\begin{array}{c}-0.013^{*} \\
(0.005)\end{array}$ & & $\begin{array}{l}-0.007 \\
(0.004)\end{array}$ \\
\hline Average Caloric Yield (All Crops, pre-1500) & & & $\begin{array}{l}0.007 \\
(0.003)\end{array}$ & & $\begin{array}{l}0.000 \\
(0.003)\end{array}$ \\
\hline Mom's College Attendance & & & & $\begin{array}{l}0.121^{* * *} \\
(0.007)\end{array}$ & $\begin{array}{l}0.121^{* * *} \\
(0.007)\end{array}$ \\
\hline Dad's College Attendance & & & & $\begin{array}{l}0.137^{* * *} \\
(0.007)\end{array}$ & $\begin{array}{l}0.137^{* * *} \\
(0.007)\end{array}$ \\
\hline Main Geographical Controls & Yes & Yes & Yes & Yes & Yes \\
\hline Origin FE for Both Parents & No & Yes & Yes & Yes & Yes \\
\hline County FE & Yes & Yes & Yes & Yes & Yes \\
\hline Year FE & Yes & Yes & Yes & Yes & Yes \\
\hline Age FE & Yes & Yes & Yes & Yes & Yes \\
\hline Gender FE & Yes & Yes & Yes & Yes & Yes \\
\hline Marital Status FE & Yes & Yes & Yes & Yes & Yes \\
\hline Parental Origin FE & Yes & Yes & Yes & Yes & Yes \\
\hline Adjusted- $R^{2}$ & 0.08 & 0.13 & 0.13 & 0.16 & 0.16 \\
\hline$R^{2}$ & 0.24 & 0.28 & 0.28 & 0.31 & 0.31 \\
\hline Observations & 39433 & 39433 & 39433 & 39433 & 39433 \\
\hline
\end{tabular}

Notes: This table establishes the negative significant effect of sex-based grammatical gender on female college attendance. Heteroskedasticity robust standard error estimates three-way clustered by state and country of origin of both parents are reported in parentheses; *** denotes statistical significance at the $1 \%$ level, ** at the $5 \%$ level, and * at the $10 \%$ level, all for two-sided hypothesis tests.

\footnotetext{
${ }^{30}$ This result is driven by the lack of variation in the existence of periphrastic future tense of the language spoken at home, and thus, the parental countries of origin fixed-effects absorb all the potential explanatory power of periphrastic future tense.
} 


\subsection{Plow Suitability, Sex-Based Grammatical Gender, and Education of Second- Generation Female Migrants}

This section explores the effect of languages with sex-based grammatical gender on human capital accumulation of its speakers. In view of the proposed hypothesis that in a society characterized by distinct gender roles and consequently by the existence of gender bias, sex-based grammatical gender systems could have fortified the existing social structure and cultural norms, the analysis explores whether languages with sex-based grammatical gender have an adverse effect on the human capital accumulation of its female speakers. In particular, following the identification strategy exploited in the previous section, the analysis focuses on the effect of sex-based grammatical gender on college attendance of second-generation female migrants into the US.

In line with the proposed hypothesis, Table 18 establishes the negative effect of speaking a language with sex-based grammatical gender on college attendance of female speakers. In particular, accounting geographical characteristics of the homeland of the language, column (1) shows that women who speak a language with sex-based grammatical gender have 23 percentage points lower probability of attending college in comparison to women with similar observable characteristics who live in the same county and who were interviewed the same year. Nevertheless, this effect may capture the persistence of characteristics of the parental countries of origin of these women independently of grammatical gender. Thus, column (2) accounts for parental origins fixed-effects, and therefore isolates the effect of gender bias that is language-embodied from the persistent cultural effects of gender bias via nonlinguistic channels. The results suggest that sex-based grammatical gender per se has an adverse effect on the probability of attending college, lowering this probability by 2.4 percentage points. Moreover, accounting for the geographical origins of sex-based grammatical gender, Column (3) suggests that the adverse effect of sex-based grammatical gender per se on the probability of attending remains significant. Finally, as established in columns (4) and (5), the adverse effect of speaking a language with sex-based grammatical gender on female college attendance is robust the the confounding effect of parental education. Thus, the analysis in Table 18 suggests that speaking a language with sex-based grammatical gender has an adverse effect on female college attendance.

\section{Conclusion}

This research explores some of the most fundamental and intriguing mysteries about the origins of the coevolution of linguistic and cultural traits and their impact on the development process: Has the coevolution of linguistic and cultural traits contributed to the persistence of cultural characteristics and their lasting effect on economic prosperity? Have language structures merely reflected existing cultural traits or have they influenced human behavior and values and contributed directly to the development process? What are the geographical roots of the coevolution of linguistic and cultural traits? Are the geographical characteristics that triggered the coevolution of culture and language critical for the understanding of the contribution of cultural and linguistic characteristics for the wealth of nations?

The study advances the hypothesis and establishes empirically that variations in pre-industrial geographical characteristics that were conducive to higher returns to agricultural investment, gender 
gaps in agricultural productivity, and hierarchical societies, are at the root of existing cross-language variations in the structure of the future tense, and the presence of grammatical gender and politeness distinctions. Moreover, the research suggests that while language structures have largely reflected past human experience and in particular ancestral cultural traits in society, they have independently affected human behavior and economic outcomes.

The empirical methodology that is advanced in the course of this research augments the epidemiological approach and permits the analysis to isolate the effect of cultural traits that are languageembodied on human behavior from the persistent effects of culture via non-linguistic channels. In particular, it suggests that variations in the languages spoken by second-generation migrants originated from the same ancestral regions can be exploited to account for country of origin fixed-effects and thus to overcome the potential biases that could be generated by omitted ancestral characteristics.

\section{References}

Acemoglu, D., Johnson, S. and Robinson, J. A. (2001). The colonial origins of comparative development: An empirical investigation, The American Economic Review 91(5): 1369-1401.

Alesina, A., Devleeschauwer, A., Easterly, W., Kurlat, S. and Wacziarg, R. (2003). Fractionalization, Journal of Economic growth 8(2): 155-194.

Alesina, A. and Ferrara, E. L. (2005). Ethnic diversity and economic performance, Journal of economic literature 43(3): 762-800.

Alesina, A., Giuliano, P. and Nunn, N. (2013). On the origins of gender roles: Women and the plough, The Quarterly Journal of Economics 128(2): 469-530.

Altonji, J. G., Elder, T. E. and Taber, C. R. (2005). Selection on observed and unobserved variables: Assessing the effectiveness of catholic schools, Journal of Political Economy 113(1): 151-184.

Ashraf, Q. and Galor, O. (2013a). Genetic diversity and the origins of cultural fragmentation, The American Economic Review 103(3): 528-533.

Ashraf, Q. and Galor, O. (2013b). The out of africa hypothesis, human genetic diversity, and comparative economic development, The American Economic Review 103(1): 1-46.

Bisin, A. and Verdier, T. (2000). Beyond the melting pot: cultural transmission, marriage, and the evolution of ethnic and religious traits, The Quarterly Journal of Economics 115(3): 955-988.

Bouckaert, R., Lemey, P., Dunn, M., Greenhill, S. J., Alekseyenko, A. V., Drummond, A. J., Gray, R. D., Suchard, M. A. and Atkinson, Q. D. (2012). Mapping the origins and expansion of the indo-european language family, Science 337(6097): 957-960.

Brown, P. and Levinson, S. C. (1987). Politeness: Some universals in language usage, Vol. 4, Cambridge university press.

Brown, R. and Gilman, A. (1989). Politeness theory and shakespeare's four major tragedies, Language in society 18(02): 159-212.

Bybee, J. L. and Dahl, Ö. (1989). The creation of tense and aspect systems in the languages of the world, Studies in language 13(1): 51-103.

Bybee, J. L. and Pagliuca, W. (1987). The evolution of future meaning, Papers from the 7th international conference on historical linguistics, Amsterdam: John Benjamins, pp. 109-122.

Bybee, J. L., Perkins, R. and Pagliuca, W. (1994). The evolution of grammar.

Cavalli-Sforza, L. L. (2000). Genes, peoples, and languages, 1st ed edn, North Point Press, New York.

Cavalli-Sforza, L. L., Menozzi, P. and Piazza, A. (1994). The history and geography of human genes, Princeton University Press, Princeton, N.J. 
Chen, M. K. (2013). The effect of language on economic behavior: Evidence from savings rates, health behaviors, and retirement assets, The American Economic Review 103(2): 690-731.

Conley, T. G. (1999). GMM estimation with cross sectional dependence, Journal of econometrics 92(1): $1-45$.

Corbett, G. G. (2013). Sex-based and non-sex-based gender systems, in M. S. Dryer and M. Haspelmath (eds), The World Atlas of Language Structures Online, Max Planck Institute for Evolutionary Anthropology, Leipzig.

Dahl, Ö. (1985). Tense and aspect systems, Basil Blackwell.

Dahl, Ö. (2000). The grammar of future time reference in european languages, Tense and Aspect in the Languages of Europe p. 309.

Dahl, Ö. and Velupillai, V. (2013). The future tense, in M. S. Dryer and M. Haspelmath (eds), The World Atlas of Language Structures Online, Max Planck Institute for Evolutionary Anthropology, Leipzig.

Depetris-Chauvin, E. and Özak, Ö. (2016). Population diversity, division of labor and comparative development, Working Paper, Southern Methodist University, Department of Economics .

Desmet, K., Ortuño-Ortín, I. and Wacziarg, R. (2012). The political economy of linguistic cleavages, Journal of development Economics 97(2): 322-338.

Diamond, J. M. (1997). Guns, germs, and steel: the fates of human societies, 1st ed edn, W.W. Norton \& Co., New York.

Dryer, Matthew S \& Haspelmath, M. e. (2013). The World Atlas of of Language Structures Online., Leipzig: Max Planck Institute for Evolutionary Anthropology.

Easterly, W. and Levine, R. (1997). Africa's growth tragedy: policies and ethnic divisions, The Quarterly Journal of Economics pp. 1203-1250.

Fearon, J. D. (2003). Ethnic and cultural diversity by country, Journal of Economic Growth 8(2): 195222.

Fenske, J. (2014). Ecology, trade, and states in pre-colonial africa, Journal of the European Economic Association 12(3): 612-640.

Figlio, D., Giuliano, P., Özek, U. and Sapienza, P. (2016). Long-term orientation and educational performance, Technical report, National Bureau of Economic Research.

Gallup, J. L., Sachs, J. D. and Mellinger, A. D. (1999). Geography and economic development, International regional science review 22(2): 179-232.

Galor, O. and Moav, O. (2002). Natural selection and the origin of economic growth, The Quarterly Journal of Economics 117(4): 1133-1191.

Galor, O. and Özak, Ö. (2015). Land productivity and economic development: Caloric suitability vs. agricultural suitability, Working Paper, Southern Methodist University, Department of Economics .

Galor, O. and Özak, Ö. (2016). The agricultural origins of time preference, American Economic Review 106(10): 3064-3103.

Giuliano, P. (2007). Living arrangements in western europe: Does cultural origin matter?, Journal of the European Economic Association 5(5): 927-952.

Glaeser, E. L., La Porta, R., Lopez-de Silanes, F. and Shleifer, A. (2004). Do institutions cause growth?, Journal of economic Growth 9(3): 271-303.

Guiso, L., Sapienza, P. and Zingales, L. (2004). The role of social capital in financial development, American Economic Review 94(3): 526-556.

Guiso, L., Sapienza, P. and Zingales, L. (2006). Does culture affect economic outcomes?, Journal of Economic Perspectives 20(2): 23-48.

Harutyunyan, A. and Özak, Ö. (2016). Culture, diffusion, and economic development, SMU Working Paper Series .

Helmbrecht, J. (2003). Politeness distinctions in second person pronouns, Pragmatics and beyond New Series pp. 185-202. 
Helmbrecht, J. (2005). Politeness distinctions in pronouns, The world atlas of language structures pp. $186-190$.

Helmbrecht, J. (2013). Politeness distinctions in pronouns, in M. S. Dryer and M. Haspelmath (eds), The World Atlas of Language Structures Online, Max Planck Institute for Evolutionary Anthropology, Leipzig.

Hofstede, G. H., Hofstede, G. J. and Minkov, M. (2010). Cultures and organizations: software of the mind : intercultural cooperation and its importance for survival, 3rd ed edn, McGraw-Hill, New York.

Lewis, M. P., Simons, G. F. and Fennig, C. D. (2009). Ethnologue: Languages of the world, Vol. 16, SIL international Dallas, TX.

Litina, A. (2014). The geographical origins of early state formation, Technical report, Center for Research in Economic Analysis, University of Luxembourg.

Michalopoulos, S. (2012). The origins of ethnolinguistic diversity, The American Economic Review 102(4): 1508.

Murdock, G. P. (1967). Ethnographic atlas: a summary, Ethnology pp. 109-236.

Murdock, G. P. and White, D. R. (1969). Standard cross-cultural sample, Ethnology pp. 329-369.

Nunn, N. and Wantchekon, L. (2011). The slave trade and the origins of mistrust in africa, American Economic Review 101(7): 3221-52.

Olson, D. M., Dinerstein, E., Wikramanayake, E. D., Burgess, N. D., Powell, G. V., Underwood, E. C., D'amico, J. A., Itoua, I., Strand, H. E., Morrison, J. C. et al. (2001). Terrestrial ecoregions of the world: A new map of life on earth a new global map of terrestrial ecoregions provides an innovative tool for conserving biodiversity, BioScience 51(11): 933-938.

Oster, E. (2014). Unobservable selection and coefficient stability: Theory and validation.

Pagel, M., Atkinson, Q. D., Calude, A. S. and Meade, A. (2013). Ultraconserved words point to deep language ancestry across eurasia, Proceedings of the National Academy of Sciences 110(21): 84718476.

Pryor, F. L. (1985). The invention of the plow, Comparative Studies in Society and history 27(04): 727743.

Richerson, P. J., Boyd, R. and Henrich, J. (2010). Gene-culture coevolution in the age of genomics, Proceedings of the National Academy of Sciences 107(Supplement 2): 8985-8992.

Roberts, S. G., Winters, J. and Chen, K. (2015). Future tense and economic decisions: controlling for cultural evolution, PloS one 10(7): e0132145.

Ruggles, S., Genadek, K., Goeken, R., Grover, J. and Sobek, M. (2015). Integrated Public Use Microdata Series: Version 6.0 [Machine-readable database], University of Minnesota, Minneapolis.

Spolaore, E. and Wacziarg, R. (2013). Long-term barriers to economic development, Handbook of Economic Growth, Vol. 2, Elsevier, p. 121. 


\section{Appendix (Not for publication)}

\section{A The Origins of Periphrastic Future Tense}

\section{A.1 Crop Return and Periphrastic Future Tense}

Table A.1: Crop Return and Periphrastic Future Tense (OLS)

\begin{tabular}{|c|c|c|c|c|c|c|c|c|c|}
\hline & \multicolumn{9}{|c|}{ Existence of Periphrastic Future Tense } \\
\hline & $(1)$ & $(2)$ & $(3)$ & $(4)$ & $(5)$ & $(6)$ & $(7)$ & $(8)$ & $(9)$ \\
\hline Crop Return (pre-1500CE) & $\begin{array}{l}0.06 * * \\
(0.03)\end{array}$ & $\begin{array}{l}0.08^{* *} \\
(0.03)\end{array}$ & $\begin{array}{l}0.08^{* *} \\
(0.03)\end{array}$ & $\begin{array}{l}0.08^{* *} \\
(0.03)\end{array}$ & $\begin{array}{l}0.09^{* *} \\
(0.03)\end{array}$ & $\begin{array}{l}0.08 * * \\
(0.03)\end{array}$ & $\begin{array}{l}0.09 * * \\
(0.04)\end{array}$ & $\begin{array}{l}0.09^{* *} \\
(0.03)\end{array}$ & $\begin{array}{l}0.12^{* * *} \\
(0.03)\end{array}$ \\
\hline Absolute Latitude & & & $\begin{array}{l}0.10^{*} \\
(0.05)\end{array}$ & $\begin{array}{l}0.10^{*} \\
(0.05)\end{array}$ & $\begin{array}{l}0.10^{*} \\
(0.05)\end{array}$ & $\begin{array}{l}0.08 \\
(0.05)\end{array}$ & $\begin{array}{l}0.07 \\
(0.07)\end{array}$ & $\begin{array}{l}0.10 \\
(0.11)\end{array}$ & $\begin{array}{l}0.15 \\
(0.11)\end{array}$ \\
\hline Elevation & & & & $\begin{array}{l}-0.00 \\
(0.03)\end{array}$ & $\begin{array}{l}0.02 \\
(0.04)\end{array}$ & $\begin{array}{l}0.03 \\
(0.04)\end{array}$ & $\begin{array}{l}0.01 \\
(0.04)\end{array}$ & $\begin{array}{l}0.05 \\
(0.05)\end{array}$ & $\begin{array}{l}0.03 \\
(0.05)\end{array}$ \\
\hline Ruggedness & & & & & $\begin{array}{l}-0.04 \\
(0.04)\end{array}$ & $\begin{array}{l}-0.04 \\
(0.04)\end{array}$ & $\begin{array}{l}-0.02 \\
(0.04)\end{array}$ & $\begin{array}{l}-0.02 \\
(0.04)\end{array}$ & $\begin{array}{l}-0.02 \\
(0.04)\end{array}$ \\
\hline Coast Length & & & & & & $\begin{array}{l}0.06^{* * * *} \\
(0.02)\end{array}$ & $\begin{array}{l}0.05^{* * *} \\
(0.02)\end{array}$ & $\begin{array}{l}0.05^{* * *} \\
(0.01)\end{array}$ & $\begin{array}{l}0.05^{* * *} \\
(0.02)\end{array}$ \\
\hline Precipitation $(\mathrm{mm} / \mathrm{month})$ & & & & & & & $\begin{array}{l}-0.01 \\
(0.09)\end{array}$ & $\begin{array}{l}-0.01 \\
(0.09)\end{array}$ & $\begin{array}{l}0.01 \\
(0.08)\end{array}$ \\
\hline Precipitation $(\mathrm{mm} / \mathrm{month})(\mathrm{std})$ & & & & & & & $\begin{array}{l}0.09 * * * \\
(0.03)\end{array}$ & $\begin{array}{l}0.05 \\
(0.05)\end{array}$ & $\begin{array}{l}0.05 \\
(0.05)\end{array}$ \\
\hline Precipitation Volatility & & & & & & & $\begin{array}{l}-0.04 \\
(0.09)\end{array}$ & $\begin{array}{l}-0.04 \\
(0.09)\end{array}$ & $\begin{array}{l}-0.04 \\
(0.08)\end{array}$ \\
\hline Precipitation Spatial Correlation & & & & & & & $\begin{array}{l}0.02 \\
(0.04)\end{array}$ & $\begin{array}{l}1.06^{* * *} \\
(0.31)\end{array}$ & $\begin{array}{l}1.01^{* * *} \\
(0.32)\end{array}$ \\
\hline Temperature (Daily Mean) & & & & & & & & $\begin{array}{l}0.08 \\
(0.09)\end{array}$ & $\begin{array}{l}0.08 \\
(0.08)\end{array}$ \\
\hline Temperature (Daily Mean) (std) & & & & & & & & $\begin{array}{l}0.05 \\
(0.05)\end{array}$ & $\begin{array}{l}0.06 \\
(0.05)\end{array}$ \\
\hline Temperature Volatility & & & & & & & & $\begin{array}{l}-0.04 \\
(0.09)\end{array}$ & $\begin{array}{l}-0.09 \\
(0.09)\end{array}$ \\
\hline Temperature Spatial Correlation & & & & & & & & $\begin{array}{l}-1.04^{* * *} \\
(0.31)\end{array}$ & $\begin{array}{l}-0.99 \text { *** } \\
(0.31)\end{array}$ \\
\hline Unproductive Period (pre-1500CE) & & & & & & & & & $\begin{array}{l}0.09 * * * \\
(0.03)\end{array}$ \\
\hline Regional FE & No & Yes & Yes & Yes & Yes & Yes & Yes & Yes & Yes \\
\hline Adjusted- $R^{2}$ & 0.01 & 0.03 & 0.04 & 0.04 & 0.04 & 0.05 & 0.06 & 0.09 & 0.11 \\
\hline Observations & 275 & 275 & 275 & 275 & 275 & 275 & 275 & 275 & 275 \\
\hline
\end{tabular}

Notes: This table replicates the analysis of Table 1 using an OLS estimation. The results are similar to the ones reported in Table 1, and thus the table provides evidence that the analysis is robust to different estimation methods. Heteroskedasticity robust standard error estimates are reported in parentheses; ${ }^{* * *}$ denotes statistical significance at the $1 \%$ level, $* *$ at the $5 \%$ level, and * at the $10 \%$ level, all for two-sided hypothesis tests. 


\section{A.2 Persistent Effect of Urheimat's Crop Return on Periphrastic Future Tense}

Table A.2: Persistent Effect of Urheimat Characteristics: Share of Daughter Languages with Periphrastic Future Tense

\begin{tabular}{|c|c|c|c|c|c|}
\hline & \multicolumn{5}{|c|}{ Share of Daughter Languages with Periphrastic Future Tense } \\
\hline & (1) & $(2)$ & $(3)$ & $(4)$ & (5) \\
\hline Crop Return (pre-1500CE) & $\begin{array}{l}0.12^{* *} \\
(0.05)\end{array}$ & $\begin{array}{l}0.16^{* * *} \\
(0.06)\end{array}$ & $\begin{array}{l}0.16^{* * *} \\
(0.05)\end{array}$ & $\begin{array}{l}0.17^{* * *} \\
(0.06)\end{array}$ & $\begin{array}{l}0.19^{* * *} \\
(0.06)\end{array}$ \\
\hline Regional FE & No & Yes & Yes & Yes & Yes \\
\hline Main Geographical Controls & No & No & Yes & Yes & Yes \\
\hline Precipitation Controls & No & No & No & Yes & Yes \\
\hline Temperature Controls & No & No & No & No & Yes \\
\hline Unproductive Period & Yes & Yes & Yes & Yes & Yes \\
\hline Observations & 74 & 74 & 74 & 74 & 74 \\
\hline
\end{tabular}

Notes: This table replicates Table 6 without weighting the observations. It establishes the robust positive statistically and economically significant relation between the Urheimat's crop return and the share of daughter languages that have periphrastic future tense. The coefficients in the table are the average marginal effects of increasing crop return in the Urheimat in a zero-inflated fractional regression. Heteroskedasticity robust standard error estimates are reported in parentheses; *** denotes statistical significance at the $1 \%$ level, ${ }^{* *}$ at the $5 \%$ level, and $*$ at the $10 \%$ level, all for two-sided hypothesis tests.

Table A.3: Crop Return and Periphrastic Future Tense across Language Families

\begin{tabular}{llllll}
\hline \hline & \multicolumn{5}{c}{ Existence of Periphrastic Future Tense } \\
\cline { 2 - 6 } & $(1)$ & $(2)$ & $(3)$ & $(4)$ & $(5)$ \\
\hline Crop Return (pre-1500CE) & $0.13^{* *}$ & $0.19^{* * *}$ & $0.18^{* * *}$ & $0.19^{* * *}$ & $0.25^{* * *}$ \\
& $(0.05)$ & $(0.06)$ & $(0.05)$ & $(0.06)$ & $(0.07)$ \\
\hline Regional FE & No & Yes & Yes & Yes & Yes \\
Main Geographical Controls & No & No & Yes & Yes & Yes \\
Precipitation Controls & No & No & No & Yes & Yes \\
Temperature Controls & No & No & No & No & Yes \\
Unproductive Period & Yes & Yes & Yes & Yes & Yes \\
Pseudo- $R^{2}$ & 0.06 & 0.12 & 0.19 & 0.23 & 0.39 \\
Observations & 74 & 74 & 74 & 74 & 74 \\
\hline
\end{tabular}

Notes: This table establishes the negative economically and statistically significant effect of the Urheimat's crop return and the existence of a future tense in a proto language, assuming that the existence of periphrastic future tense in a majority of daughter languages in a language family represents the existence of the future tense in the proto language. Observations are not weighted. Heteroskedasticity robust standard error estimates are reported in parentheses; $* * *$ denotes statistical significance at the $1 \%$ level, $* *$ at the $5 \%$ level, and * at the $10 \%$ level, all for two-sided hypothesis tests. 
Table A.4: Crop Return and Periphrastic Future Tense across Language Families

\begin{tabular}{llllllll}
\hline \hline & \multicolumn{6}{c}{ Existence of Periphrastic Future Tense } \\
\cline { 2 - 7 } & \multicolumn{1}{c}{$(1)$} & $(2)$ & $(3)$ & $(4)$ & $(5)$ & \multicolumn{1}{c}{$(6)$} \\
\hline Crop Return (pre-1500CE) & $0.21^{* * *}$ & $0.28^{* * *}$ & $0.27^{* * *}$ & $0.26^{* * *}$ & $0.24^{* * *}$ & $0.27^{* * *}$ \\
& $(0.06)$ & $(0.04)$ & $(0.05)$ & $(0.05)$ & $(0.06)$ & $(0.07)$ \\
\hline Regional FE & No & Yes & Yes & Yes & Yes & Yes \\
Main Geographical Controls & No & No & Yes & Yes & Yes & Yes \\
Precipitation Controls & No & No & No & Yes & Yes & Yes \\
Temperature Controls & No & No & No & No & Yes & Yes \\
Unproductive Period & No & No & No & No & No & Yes \\
Pseudo- $R^{2}$ & 0.15 & 0.35 & 0.41 & 0.52 & 0.57 & 0.57 \\
Observations & 74 & 74 & 74 & 74 & 74 & 74 \\
\hline
\end{tabular}

Notes: This table establishes the positive economically and statistically significant effect of the Urheimat's crop return and the existence of a future tense in a proto-language, assuming that the existence of periphrastic future tense in a majority of daughter languages in a language family represents the existence of the future tense in the proto language. Observations are weighted to account for missing languages and future tense data.. Heteroskedasticity robust standard error estimates are reported in parentheses; $* * *$ denotes statistical significance at the $1 \%$ level, ** at the $5 \%$ level, and * at the $10 \%$ level, all for two-sided hypothesis tests.

Table A.5: Crop Return and Periphrastic Future Tense across Language Families

\begin{tabular}{lllllll}
\hline \hline & \multicolumn{6}{c}{ Existence of Periphrastic Future Tense } \\
\cline { 2 - 7 } & \multicolumn{1}{c}{$(1)$} & $(2)$ & $(3)$ & $(4)$ & $(5)$ & $(6)$ \\
\hline Crop Return (pre-1500CE) & $0.24^{* * *}$ & $0.28^{* * *}$ & $0.32^{* * *}$ & $0.35^{* * *}$ & $0.36^{* * *}$ & $0.37^{* * *}$ \\
& $(0.06)$ & $(0.05)$ & $(0.05)$ & $(0.05)$ & $(0.08)$ & $(0.08)$ \\
Unproductive Period (pre-1500CE) & & & & & & 0.02 \\
& & & & & & $(0.08)$ \\
\hline Regional FE & No & Yes & Yes & Yes & Yes & Yes \\
Main Geographical Controls & No & No & Yes & Yes & Yes & Yes \\
Precipitation Controls & No & No & No & Yes & Yes & Yes \\
Temperature Controls & No & No & No & No & Yes & Yes \\
Pseudo- $R^{2}$ & 0.18 & 0.28 & 0.38 & 0.50 & 0.60 & 0.60 \\
Observations & 64 & 64 & 64 & 64 & 64 & 64 \\
\hline
\end{tabular}

Notes: This table establishes the positive, statistically, and economically significant effect of pre-1500CE potential crop return on the existence of periphrastic future tense, accounting for regional fixed-effects and the set of geographical characteristics in Table 1. All independent variables have been normalized by subtracting their mean and dividing by their standard deviation at the language level, and the median at the language level is used in the analysis. Thus, all coefficients can be compared and show the effect of a one standard deviation in the independent variable on the probability of having a future tense in the language. Coefficients estimated using a weighted Probit, where weights correct representativeness of each language family in sample. For all variables the language family mean value is used in the analysis. Heteroskedasticity robust standard error estimates are reported in parentheses; *** denotes statistical significance at the $1 \%$ level, ** at the $5 \%$ level, and * at the $10 \%$ level, all for two-sided hypothesis tests. 
Table A.6: Crop Return and Periphrastic Future Tense across Language Families

\begin{tabular}{lllllll}
\hline \hline & \multicolumn{5}{c}{ Existence of Periphrastic Future Tense (Median) } \\
\cline { 2 - 7 } & \multicolumn{1}{c}{$(1)$} & $(2)$ & $(3)$ & $(4)$ & $(5)$ & $(6)$ \\
\hline Crop Return (pre-1500CE) & $0.28^{* * *}$ & $0.38^{* * *}$ & $0.37^{* * *}$ & $0.41^{* * *}$ & $0.41^{* * *}$ & $0.43^{* * *}$ \\
& $(0.03)$ & $(0.05)$ & $(0.05)$ & $(0.07)$ & $(0.05)$ & $(0.06)$ \\
Unproductive Period (pre-1500CE) & & & & & & 0.08 \\
& & & & & & $(0.07)$ \\
\hline Regional FE & No & Yes & Yes & Yes & Yes & Yes \\
Main Geographical Controls & No & No & Yes & Yes & Yes & Yes \\
Precipitation Controls & No & No & No & Yes & Yes & Yes \\
Temperature Controls & No & No & No & No & Yes & Yes \\
Pseudo- $R^{2}$ & 0.28 & 0.51 & 0.55 & 0.64 & 0.72 & 0.73 \\
Observations & 66 & 66 & 66 & 66 & 66 & 66 \\
\hline
\end{tabular}

Notes: This table establishes the positive, statistically, and economically significant effect of pre-1500CE potential crop return on the existence of periphrastic future tense, accounting for regional fixed-effects and the set of geographical characteristics in Table 1. All independent variables have been normalized by subtracting their mean and dividing by their standard deviation. Thus, all coefficients can be compared and show the effect of a one standard deviation in the independent variable on the probability of having a future tense. Coefficients estimated using a weighted Probit, where weights correct representativeness of each language family in sample. For all variables the language family median value is used in the analysis. Heteroskedasticity robust standard error estimates are reported in parentheses; *** denotes statistical significance at the $1 \%$ level, ** at the $5 \%$ level, and * at the $10 \%$ level, all for two-sided hypothesis tests.

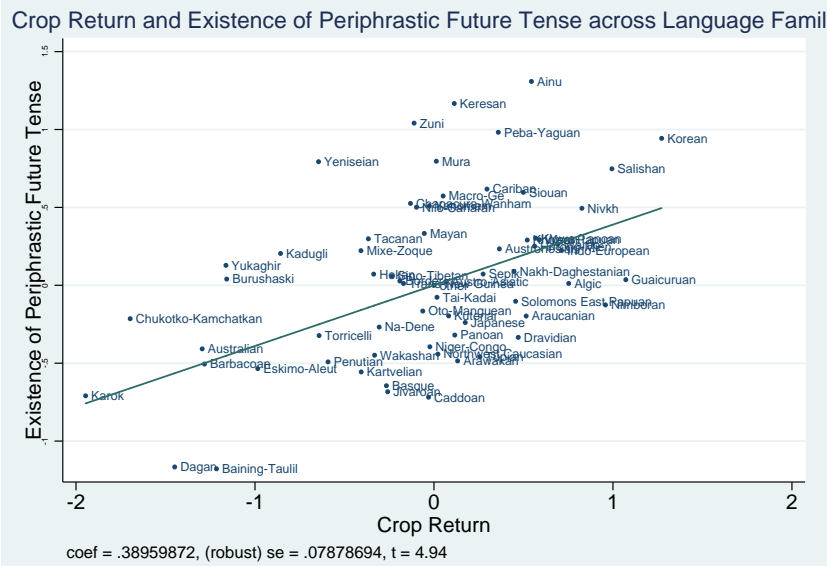

(a) Median

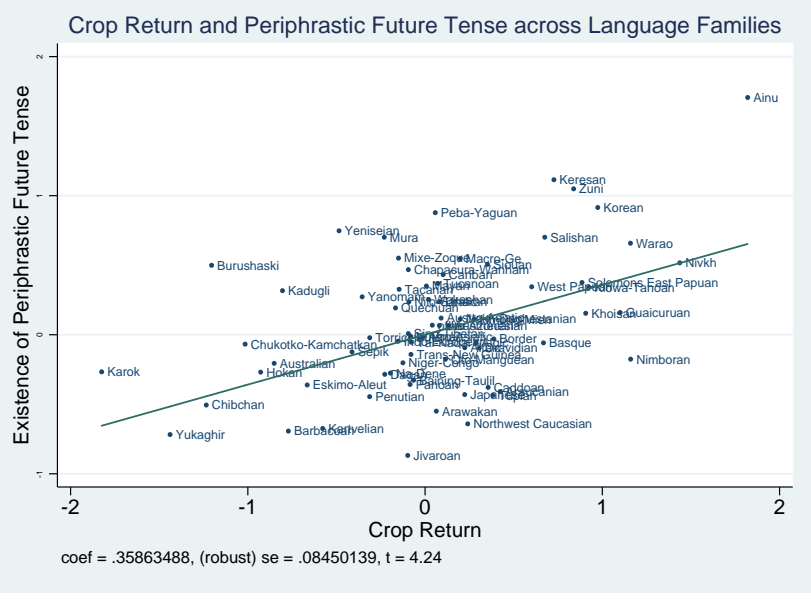

(b) Mean

Figure A.1: Crop Return and Periphrastic Future Across Language Families 
Table A.7: Crop Return and Periphrastic Future Tense across Language Genera

\begin{tabular}{lllllll}
\hline \hline & \multicolumn{6}{c}{ Existence of Periphrastic Future Tense } \\
\cline { 2 - 7 } & \multicolumn{7}{c}{$(1)$} & $(2)$ & $(3)$ & $(4)$ & $(5)$ & $(6)$ \\
\hline Crop Return (pre-1500CE) & $0.20^{* *}$ & $0.19^{* * *}$ & $0.27^{* * *}$ & $0.26^{* * *}$ & $0.25^{* * *}$ & $0.32^{* * *}$ \\
& $(0.06)$ & $(0.07)$ & $(0.07)$ & $(0.07)$ & $(0.08)$ & $(0.08)$ \\
Unproductive Period (pre-1500CE) & & & & & & $0.21^{* *}$ \\
& & & & & & $(0.07)$ \\
\hline Regional FE & No & Yes & Yes & Yes & Yes & Yes \\
Main Geographical Controls & No & No & Yes & Yes & Yes & Yes \\
Precipitation Controls & No & No & No & Yes & Yes & Yes \\
Temperature Controls & No & No & No & No & Yes & Yes \\
Pseudo- $R^{2}$ & 0.09 & 0.17 & 0.26 & 0.35 & 0.35 & 0.39 \\
Observations & 145 & 145 & 145 & 145 & 145 & 145 \\
\hline
\end{tabular}

Notes: This table establishes the positive, statistically, and economically significant effect of pre-1500CE potential crop return on the existence of periphrastic future tense, accounting for regional fixed-effects and the set of geographical characteristics in Table 1. All independent variables have been normalized by subtracting their mean and dividing by their standard deviation at the language level, and the median at the language level is used in the analysis. Thus, all coefficients can be compared and show the effect of a one standard deviation in the independent variable on the probability of having a future tense in the language. Coefficients estimated using a weighted Probit, where weights correct representativeness of each language genus in sample. For all variables the language genus mean value is used in the analysis. Heteroskedasticity robust standard error estimates are reported in parentheses; *** denotes statistical significance at the $1 \%$ level, $* *$ at the $5 \%$ level, and $*$ at the $10 \%$ level, all for two-sided hypothesis tests.

Table A.8: Crop Return and Periphrastic Future Tense across Language Genera

\begin{tabular}{lllllll}
\hline \hline & \multicolumn{5}{c}{ Existence of Periphrastic Future Tense (Median) } \\
\cline { 2 - 7 } & \multicolumn{1}{c}{$(1)$} & $(2)$ & $(3)$ & $(4)$ & $(5)$ & $(6)$ \\
\hline Crop Return (pre-1500CE) & $0.21^{* * *}$ & $0.23^{* * *}$ & $0.27^{* * *}$ & $0.28^{* * *}$ & $0.26^{* * *}$ & $0.32^{* * *}$ \\
& $(0.05)$ & $(0.07)$ & $(0.07)$ & $(0.08)$ & $(0.08)$ & $(0.09)$ \\
Unproductive Period (pre-1500CE) & & & & & & 0.13 \\
& & & & & & $(0.09)$ \\
\hline Regional FE & No & Yes & Yes & Yes & Yes & Yes \\
Main Geographical Controls & No & No & Yes & Yes & Yes & Yes \\
Precipitation Controls & No & No & No & Yes & Yes & Yes \\
Temperature Controls & No & No & No & No & Yes & Yes \\
Pseudo- $R^{2}$ & 0.13 & 0.21 & 0.26 & 0.30 & 0.31 & 0.32 \\
Observations & 141 & 141 & 141 & 141 & 141 & 141 \\
\hline
\end{tabular}

Notes: This table establishes the negative, statistically, and economically significant effect of pre-1500CE potential crop return on the existence of periphrastic future tense, accounting for regional fixed-effects and the set of geographical characteristics in Table 1. All independent variables have been normalized by subtracting their mean and dividing by their standard deviation. Thus, all coefficients can be compared and show the effect of a one standard deviation in the independent variable on the probability of having a future tense in the language. Coefficients estimated using a weighted Probit, where weights correct representativeness of each language genus in sample. For all variables the language genus median value is used in the analysis. Heteroskedasticity robust standard error estimates are reported in parentheses; *** denotes statistical significance at the $1 \%$ level, ** at the $5 \%$ level, and * at the $10 \%$ level, all for two-sided hypothesis tests. 


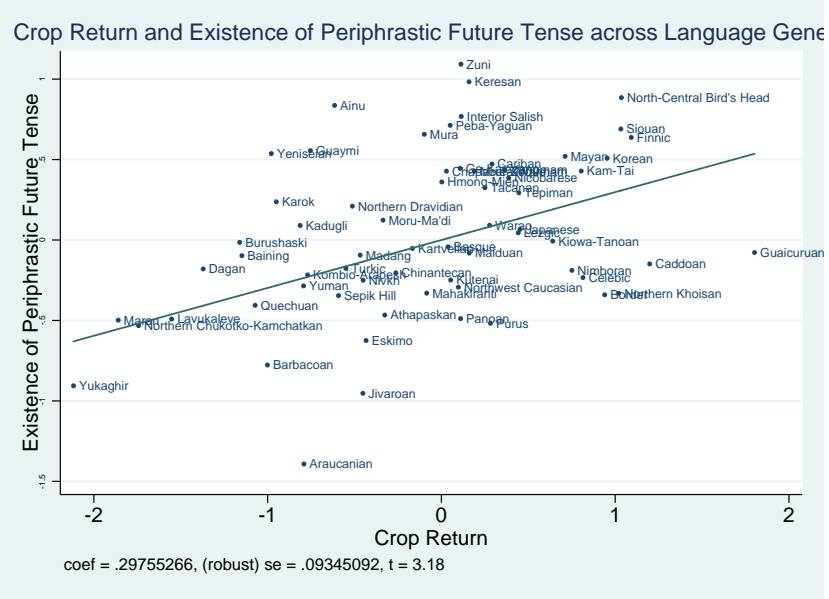

(a) Median

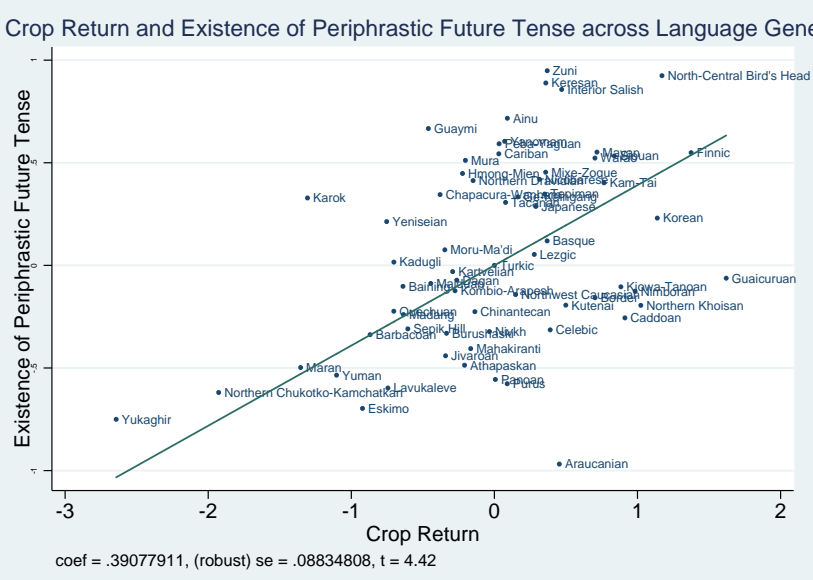

(b) Mean

Figure A.2: Crop Return and Periphrastic Future Across Language Genera

Table A.9: Crop Return and Language Structures across Language Families

\begin{tabular}{|c|c|c|c|c|c|c|c|c|c|}
\hline & \multicolumn{9}{|c|}{ Language Structure } \\
\hline & \multicolumn{3}{|c|}{ Temporal Structures } & \multicolumn{4}{|c|}{ Non-Temporal Structures } & \multirow[b]{2}{*}{ C/V Ratio } & \multirow[b]{2}{*}{ Colors } \\
\hline & Future & Past & Perfect & Gender & $\begin{array}{l}\text { Posses- } \\
\text { sive }\end{array}$ & $\begin{array}{l}\text { Eviden- } \\
\text { tiality }\end{array}$ & $\begin{array}{l}\text { Conso- } \\
\text { nants }\end{array}$ & & \\
\hline & $(1)$ & $(2)$ & $(3)$ & $(4)$ & $(5)$ & $(6)$ & $(7)$ & $(8)$ & (9) \\
\hline Crop Return (pre-1500CE) & $\begin{array}{l}0.36^{* * *} \\
(0.08)\end{array}$ & $\begin{array}{l}-0.14 \\
(0.14)\end{array}$ & $\begin{array}{l}-0.09 \\
(0.13)\end{array}$ & $\begin{array}{l}0.01 \\
(0.13)\end{array}$ & $\begin{array}{l}-0.11 \\
(0.14)\end{array}$ & $\begin{array}{l}-0.02 \\
(0.07)\end{array}$ & $\begin{array}{l}0.28^{*} \\
(0.16)\end{array}$ & $\begin{array}{l}0.14 \\
(0.19)\end{array}$ & $\begin{array}{l}0.11 \\
(1.12)\end{array}$ \\
\hline All Geographic Controls & Yes & Yes & Yes & Yes & Yes & Yes & Yes & Yes & Yes \\
\hline Regional FE & Yes & Yes & Yes & Yes & Yes & Yes & Yes & Yes & Yes \\
\hline Adjusted- $R^{2}$ & 0.48 & 0.23 & 0.08 & 0.19 & 0.27 & 0.70 & 0.66 & 0.48 & -0.02 \\
\hline Observations & 73 & 73 & 73 & 59 & 64 & 71 & 73 & 73 & 29 \\
\hline
\end{tabular}

Notes: This table establishes the positive, statistically, and economically significant effect of pre-1500CE potential crop return on the existence of periphrastic future tense in a language family, and not with other language structures. The analysis accounts for regional fixed-effects and other geographical characteristics as in previous tables. Other language structures include the existence a past tense, a perfect tense, the number of genders, the existence of obligatory possessive inflections, semantic distinctions of evidentiality, the number of consonants, the ratio of consonants to vowels and the number of colors. Coefficients estimated using a weighted Probit, where weights correct representativeness of each language family in sample. For all variables the language family mean value is used in the analysis. Heteroskedasticity robust standard error estimates are reported in parentheses; $* * *$ denotes statistical significance at the $1 \%$ level, ${ }^{* *}$ at the $5 \%$ level, and $*$ at the $10 \%$ level, all for two-sided hypothesis tests. 
Table A.10: Crop Return and Language Structures across Language Families

\begin{tabular}{|c|c|c|c|c|c|c|c|c|c|}
\hline & \multicolumn{9}{|c|}{ Language Structure } \\
\hline & \multicolumn{3}{|c|}{ Temporal Structures } & \multicolumn{4}{|c|}{ Non-Temporal Structures } & \multirow[b]{2}{*}{$\mathrm{C} / \mathrm{V}$ Ratio } & \multirow[b]{2}{*}{ Colors } \\
\hline & Future & Past & Perfect & Gender & $\begin{array}{l}\text { Posses- } \\
\text { sive }\end{array}$ & $\begin{array}{l}\text { Eviden- } \\
\text { tiality }\end{array}$ & $\begin{array}{l}\text { Conso- } \\
\text { nants }\end{array}$ & & \\
\hline & $(1)$ & $(2)$ & (3) & $(4)$ & $(5)$ & $(6)$ & $(7)$ & (8) & $(9)$ \\
\hline Crop Return (pre-1500CE) & $\begin{array}{l}0.39^{* * *} \\
(0.08)\end{array}$ & $\begin{array}{l}-0.10 \\
(0.11)\end{array}$ & $\begin{array}{l}0.10 \\
(0.14) \\
\end{array}$ & $\begin{array}{l}0.14 \\
(0.14)\end{array}$ & $\begin{array}{l}0.13 \\
(0.13) \\
\end{array}$ & $\begin{array}{l}0.08 \\
(0.07)\end{array}$ & $\begin{array}{l}0.46^{* * *} \\
(0.16)\end{array}$ & $\begin{array}{l}0.30 \\
(0.18)\end{array}$ & $\begin{array}{l}1.42 \\
(2.68) \\
\end{array}$ \\
\hline All Geographic Controls & Yes & Yes & Yes & Yes & Yes & Yes & Yes & Yes & Yes \\
\hline Regional FE & Yes & Yes & Yes & Yes & Yes & Yes & Yes & Yes & Yes \\
\hline Adjusted- $R^{2}$ & 0.49 & 0.38 & 0.20 & 0.09 & 0.20 & 0.79 & 0.80 & 0.55 & 0.38 \\
\hline Observations & 66 & 66 & 66 & 52 & 57 & 64 & 66 & 66 & 25 \\
\hline
\end{tabular}

Notes: This table establishes the positive, statistically, and economically significant effect of pre-1500CE potential crop return on the existence of periphrastic future tense in a language family, and not with other language structures. The analysis accounts for regional fixed-effects and other geographical characteristics as in previous tables. Other language structures include the existence a past tense, a perfect tense, the number of genders, the existence of obligatory possessive inflections, semantic distinctions of evidentiality, the number of consonants, the ratio of consonants to vowels and the number of colors. Coefficients estimated using a weighted Probit, where weights correct representativeness of each language family in sample. For all variables the language family median value is used in the analysis. Heteroskedasticity robust standard error estimates are reported in parentheses; $* * *$ denotes statistical significance at the $1 \%$ level, ${ }^{* *}$ at the $5 \%$ level, and ${ }^{*}$ at the $10 \%$ level, all for two-sided hypothesis tests.

Table A.11: Crop Return and Periphrastic Future Tense Across Language Families (Monte Carlo)

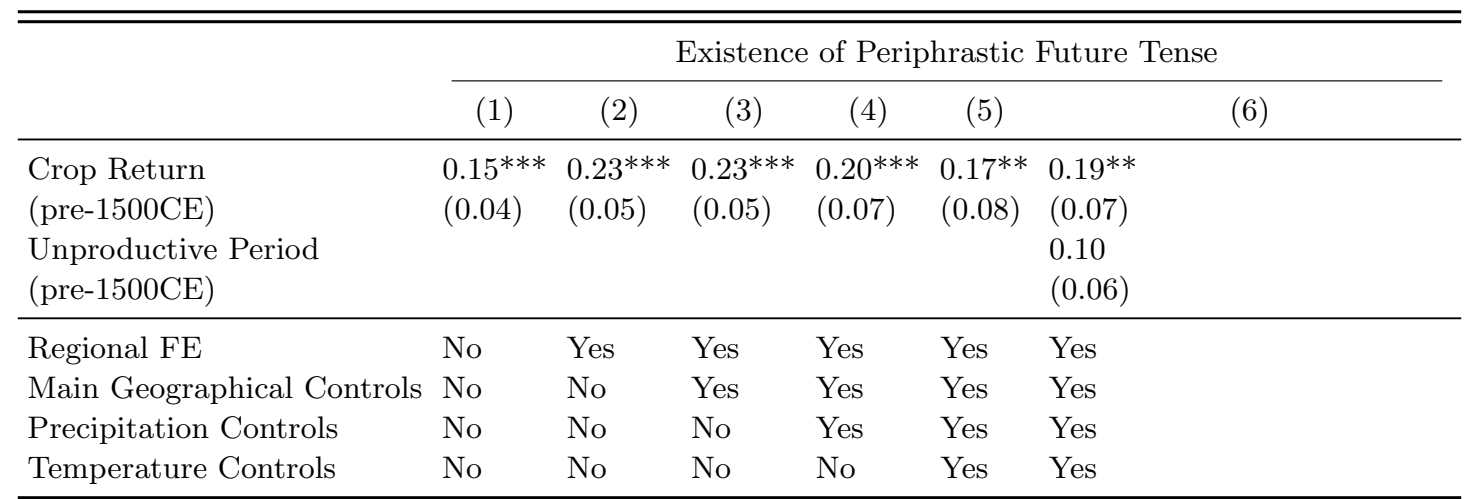

Notes: This table establishes the positive, statistically, and economically significant effect of pre-1500CE potential crop return on the existence of periphrastic future tense, accounting for regional fixed-effects and the set of geographical characteristics in Table 1. Estimates based on Monte Carlo simulations sampling one language for each language family in each simulation. The results are based on 76 Language families and 5000 simulations. All independent variables have been normalized by subtracting their mean and dividing by their standard deviation at the language level. Thus, all coefficients can be compared and show the effect of a one standard deviation in the independent variable on the probability of having a future tense in the language. Heteroskedasticity robust standard error estimates are reported in parentheses; *** denotes statistical significance at the $1 \%$ level, ** at the $5 \%$ level, and * at the $10 \%$ level, all for two-sided hypothesis tests. 
Table A.12: Crop Return and Periphrastic Future Tense Across Language Families (Monte Carlo)

\begin{tabular}{lllllll}
\hline \hline & \multicolumn{6}{c}{ Existence of Periphrastic Future Tense } \\
\cline { 2 - 7 } & \multicolumn{7}{c}{$(1)$} & $(2)$ & $(3)$ & $(4)$ & $(5)$ & $(6)$ \\
\hline Crop Return (pre-1500CE) & $0.17^{* * *}$ & $0.24^{* * *}$ & $0.23^{* * *}$ & $0.20^{* * *}$ & $0.19^{* *}$ & $0.20^{* * *}$ \\
& $(0.04)$ & $(0.04)$ & $(0.05)$ & $(0.07)$ & $(0.08)$ & $(0.08)$ \\
Unproductive Period (pre-1500CE) & & & & & & 0.10 \\
& & & & & & $(0.07)$ \\
\hline Regional FE & No & Yes & Yes & Yes & Yes & Yes \\
Main Geographical Controls & No & No & Yes & Yes & Yes & Yes \\
Precipitation Controls & No & No & No & Yes & Yes & Yes \\
Temperature Controls & No & No & No & No & Yes & Yes \\
\hline
\end{tabular}

Notes: This table establishes the positive, statistically, and economically significant effect of pre-1500CE potential crop return on the existence of periphrastic future tense, accounting for regional fixed-effects and the set of geographical characteristics in Table 1. Estimates based on Monte Carlo simulations sampling one language for each language family in each simulation. The analysis assumes that the median level of future in the family represents the proto-language. The results are based on 76 Language families and 5000 simulations. All independent variables have been normalized by subtracting their mean and dividing by their standard deviation at the language level. Thus, all coefficients can be compared and show the effect of a one standard deviation in the independent variable on the probability of having a future tense in the language. Heteroskedasticity robust standard error estimates are reported in parentheses; *** denotes statistical significance at the $1 \%$ level, ** at the $5 \%$ level, and * at the $10 \%$ level, all for two-sided hypothesis tests. 


\section{A.3 Mechanisms}

Table A.13: Agricultural Intensity and Existence of Periphrastic Future Tense

\begin{tabular}{|c|c|c|c|c|c|c|c|}
\hline & \multicolumn{7}{|c|}{ Existence of Periphrastic Future Tense } \\
\hline & \multicolumn{5}{|c|}{ OLS } & \multirow{2}{*}{\multicolumn{2}{|c|}{$\frac{\text { IV }}{\text { (6) }}$}} \\
\hline & $(1)$ & $(2)$ & $(3)$ & $(4)$ & $(5)$ & & \\
\hline Agricultural Intensity & $\begin{array}{l}0.07^{* *} \\
(0.03)\end{array}$ & $\begin{array}{l}0.11^{* * *} \\
(0.04)\end{array}$ & $\begin{array}{l}0.10^{* *} \\
(0.04)\end{array}$ & $\begin{array}{l}0.09 * * \\
(0.04)\end{array}$ & $\begin{array}{l}0.10^{* *} \\
(0.04)\end{array}$ & $\begin{array}{l}0.34^{* * *} \\
(0.10)\end{array}$ & \\
\hline Regional FE & No & Yes & Yes & Yes & Yes & Yes & \\
\hline Main Geographic Controls & No & No & Yes & Yes & Yes & Yes & \\
\hline Main Precipitation Controls & No & No & No & Yes & Yes & Yes & \\
\hline Main Temperature Controls & No & No & No & No & Yes & Yes & \\
\hline First-stage F-statistic & & & & & & 18.78 & \\
\hline Hansen's J-statistic & & & & & & 5.04 & \\
\hline J-stat p-value & & & & & & 0.02 & \\
\hline Adjusted- $R^{2}$ & 0.02 & 0.06 & 0.07 & 0.08 & 0.13 & 0.03 & \\
\hline Observations & 264 & 264 & 264 & 264 & 264 & 264 & \\
\hline
\end{tabular}

Notes: This table establishes the positive statistically and economically significant effect of agricultural intensity on the existence of periphrastic future tense in the language spoken by a pre-modern society. The table replicates Table 8 in columns (1)-(5) using OLS and also instruments agricultural suitability with crop return and the length of the unproductive period, both of which affect a society's agricultural intensity. Reassuringly, the OLS estimates are similar to the Probit ones, while the IV estimates are 3.4 times larger, suggesting that a one standard deviation increase in agricultural suitability would decrease the probability of the existence of a future tense by 0.34 percentage points. While this hints that the estimates in Table 8 might be biased towards zero, the overidentification test in Table A.13 suggests that the IV does not satisfy the exclusion restriction. Heteroskedasticity robust standard error estimates are reported in parentheses; *** denotes statistical significance at the $1 \%$ level, ${ }^{* *}$ at the $5 \%$ level, and $*$ at the $10 \%$ level, all for two-sided hypothesis tests.

Table A.14: Crop Return, Agricultural Suitability and Periphrastic Future Tense

\begin{tabular}{|c|c|c|c|c|c|c|}
\hline & \multicolumn{6}{|c|}{ Existence of Periphrastic Future Tense } \\
\hline & (1) & $(2)$ & $(3)$ & $(4)$ & $(5)$ & $(6)$ \\
\hline Crop Return (pre-1500CE) & $\begin{array}{l}0.12^{* * *} \\
(0.03)\end{array}$ & & & $\begin{array}{l}0.13^{* *} \\
(0.05)\end{array}$ & $\begin{array}{l}0.15^{* * *} \\
(0.03)\end{array}$ & $\begin{array}{l}0.12^{* *} \\
(0.05)\end{array}$ \\
\hline Caloric Suitability (pre-1500CE) & & $\begin{array}{l}0.08^{* *} \\
(0.03)\end{array}$ & & $\begin{array}{l}-0.01 \\
(0.05)\end{array}$ & & $\begin{array}{l}0.04 \\
(0.05)\end{array}$ \\
\hline Agricultural Suitability (mean) & & & $\begin{array}{l}-0.09 \\
(0.12)\end{array}$ & & $\begin{array}{l}-0.28^{* *} \\
(0.12)\end{array}$ & $\begin{array}{l}-0.32^{* *} \\
(0.13)\end{array}$ \\
\hline All Geographic Controls & Yes & Yes & Yes & Yes & Yes & Yes \\
\hline Regional FE & Yes & Yes & Yes & Yes & Yes & Yes \\
\hline Pseudo- $R^{2}$ & 0.14 & 0.12 & 0.11 & 0.14 & 0.15 & 0.16 \\
\hline Observations & 275 & 275 & 275 & 275 & 275 & 275 \\
\hline
\end{tabular}




\section{B Language Structures \& Contemporary Behavior}

\section{B.1 Crop Return, Periphrastic Future Tense, and Long-Term Oriented Behavior of Second-Generation Migrants}

Table B.1: Pre-1500CE Crop Return, Periphrastic Future Tense, and College Education of Second and Higher Generation Migrants

\begin{tabular}{llllll}
\hline \hline & \multicolumn{5}{c}{ College Attendance } \\
\cline { 2 - 6 } & \multicolumn{1}{c}{$(1)$} & $(2)$ & $(3)$ & $(4)$ & $(5)$ \\
\hline Periphrastic Future Tense & $0.100^{* * *}$ & $0.132^{* * *}$ & $0.125^{* * *}$ & & $0.111^{* * *}$ \\
& $(0.014)$ & $(0.005)$ & $(0.004)$ & & $(0.004)$ \\
Crop Return (pre-1500CE) & & & & $0.034^{* * *}$ & $0.019^{* * *}$ \\
& & & & $(0.001)$ & $(0.001)$ \\
\hline Main Geographical Controls & Yes & Yes & Yes & Yes & Yes \\
State FE & Yes & Yes & Yes & Yes & Yes \\
Year FE & Yes & Yes & Yes & Yes & Yes \\
Age FE & No & Yes & Yes & Yes & Yes \\
Gender FE & No & Yes & Yes & Yes & Yes \\
Marital Status FE & No & No & Yes & Yes & Yes \\
Adjusted- $R^{2}$ & 0.02 & 0.07 & 0.08 & 0.08 & 0.08 \\
$R^{2}$ & 0.02 & 0.07 & 0.09 & 0.09 & 0.09 \\
Observations & 12206839 & 12206839 & 12206839 & 12206839 & 12206839 \\
\hline
\end{tabular}

Table B.2: Pre-1500CE Crop Return, Periphrastic Future Tense, and College Education One-and-a-Half Generation Migrants (Who Arrived at Age $\leq 5$ )

\begin{tabular}{|c|c|c|c|c|c|c|}
\hline & \multicolumn{6}{|c|}{ College Attendance } \\
\hline & \multicolumn{4}{|c|}{ Language } & \multirow{2}{*}{$\frac{\text { Crop Return }}{(5)}$} & \multirow{2}{*}{$\begin{array}{c}\text { Both } \\
(6)\end{array}$} \\
\hline & $(1)$ & $(2)$ & $(3)$ & (4) & & \\
\hline Periphrastic Future Tense & $\begin{array}{l}0.205^{* * *} \\
(0.013)\end{array}$ & $\begin{array}{l}0.208^{* * *} \\
(0.007)\end{array}$ & $\begin{array}{l}0.204^{* * *} \\
(0.005)\end{array}$ & $\begin{array}{l}0.056^{* * *} \\
(0.007)\end{array}$ & & $\begin{array}{l}0.054^{* * *} \\
(0.007)\end{array}$ \\
\hline Crop Return (pre-1500CE) & & & & & $\begin{array}{l}0.011^{* * *} \\
(0.003)\end{array}$ & $\begin{array}{l}0.004 \\
(0.003)\end{array}$ \\
\hline Main Geographical Controls & Yes & Yes & Yes & Yes & Yes & Yes \\
\hline State FE & Yes & Yes & Yes & Yes & Yes & Yes \\
\hline Year FE & Yes & Yes & Yes & Yes & Yes & Yes \\
\hline Age FE & No & Yes & Yes & Yes & Yes & Yes \\
\hline Gender FE & No & Yes & Yes & Yes & Yes & Yes \\
\hline Marital Status FE & No & No & Yes & Yes & Yes & Yes \\
\hline Parental Origin FE & No & No & No & Yes & Yes & Yes \\
\hline Adjusted- $R^{2}$ & 0.06 & 0.09 & 0.10 & 0.15 & 0.15 & 0.15 \\
\hline$R^{2}$ & 0.06 & 0.11 & 0.17 & 0.48 & 0.48 & 0.48 \\
\hline Observations & 422081 & 422081 & 422081 & 422081 & 422081 & 422081 \\
\hline
\end{tabular}

Notes: Heteroskedasticity robust standard error estimates clustered at the level of the included fixed-effects are reported in parentheses; *** denotes statistical significance at the $1 \%$ level, ** at the $5 \%$ level, and * at the $10 \%$ level, all for two-sided hypothesis tests. 
Table B.3: Periphrastic Future Tense and College Education of Second Generation Migrants Accounting for Parental Education and English Levels, and Local Socio-Economic Conditions (County Level)

\begin{tabular}{|c|c|c|c|c|c|c|c|c|c|}
\hline & \multicolumn{9}{|c|}{ College Attendance } \\
\hline & \multicolumn{3}{|c|}{ Parental Education } & \multicolumn{3}{|c|}{ Parental English } & \multicolumn{3}{|c|}{ Both } \\
\hline & $(1)$ & $(2)$ & $(3)$ & $(4)$ & $(5)$ & $(6)$ & $(7)$ & $(8)$ & (9) \\
\hline Periphrastic Future Tense & $\begin{array}{l}0.032^{* * *} \\
(0.005)\end{array}$ & & $\begin{array}{l}0.029 * * * \\
(0.005)\end{array}$ & $\begin{array}{l}0.030 * * * \\
(0.006)\end{array}$ & & $\begin{array}{l}0.030^{* * *} \\
(0.006)\end{array}$ & $\begin{array}{l}0.029 * * * \\
(0.005)\end{array}$ & & $\begin{array}{l}0.027 * * * \\
(0.005)\end{array}$ \\
\hline Crop Return (pre-1500CE) & & $\begin{array}{l}0.006^{* * *} \\
(0.002)\end{array}$ & $\begin{array}{l}0.003^{* *} \\
(0.001)\end{array}$ & & $\begin{array}{l}0.003^{*} \\
(0.002)\end{array}$ & $\begin{array}{l}0.000 \\
(0.001)\end{array}$ & & $\begin{array}{l}0.005^{* * *} \\
(0.001)\end{array}$ & $\begin{array}{l}0.003^{* *} \\
(0.001)\end{array}$ \\
\hline Mom's College Attendance & $\begin{array}{l}0.131^{* * *} \\
(0.006)\end{array}$ & $\begin{array}{l}0.131^{* * *} \\
(0.006)\end{array}$ & $\begin{array}{l}0.131^{* * *} \\
(0.006)\end{array}$ & & & & $\begin{array}{l}0.133^{* * *} \\
(0.006)\end{array}$ & $\begin{array}{l}0.133^{* * *} \\
(0.006)\end{array}$ & $\begin{array}{l}0.133^{* * *} \\
(0.006)\end{array}$ \\
\hline Dad's College Attendance & $\begin{array}{l}0.141^{* * *} \\
(0.006)\end{array}$ & $\begin{array}{l}0.142^{* * *} \\
(0.006)\end{array}$ & $\begin{array}{l}0.141^{* * *} \\
(0.006)\end{array}$ & & & & $\begin{array}{l}0.143^{* * *} \\
(0.006)\end{array}$ & $\begin{array}{l}0.143^{* * *} \\
(0.006)\end{array}$ & $\begin{array}{l}0.143^{* * *} \\
(0.006)\end{array}$ \\
\hline Mom's English Level & & & & $\begin{array}{l}0.013^{* * *} \\
(0.002)\end{array}$ & $\begin{array}{l}0.013^{* * *} \\
(0.002)\end{array}$ & $\begin{array}{l}0.013^{* * *} \\
(0.002)\end{array}$ & $\begin{array}{l}0.014^{* * *} \\
(0.001)\end{array}$ & $\begin{array}{l}0.014^{* * *} \\
(0.001)\end{array}$ & $\begin{array}{l}0.014^{* * *} \\
(0.001)\end{array}$ \\
\hline Dad's English Level & & & & $\begin{array}{l}-0.001 \\
(0.002)\end{array}$ & $\begin{array}{l}-0.001 \\
(0.002)\end{array}$ & $\begin{array}{l}-0.001 \\
(0.002)\end{array}$ & $\begin{array}{l}0.006^{* * *} \\
(0.001)\end{array}$ & $\begin{array}{l}0.006^{* * *} \\
(0.001)\end{array}$ & $\begin{array}{l}0.006^{* * *} \\
(0.001)\end{array}$ \\
\hline Main Geographical Controls & Yes & Yes & Yes & Yes & Yes & Yes & Yes & Yes & Yes \\
\hline Origin FE for Both Parents & Yes & Yes & Yes & Yes & Yes & Yes & Yes & Yes & Yes \\
\hline County FE & Yes & Yes & Yes & Yes & Yes & Yes & Yes & Yes & Yes \\
\hline Year FE & Yes & Yes & Yes & Yes & Yes & Yes & Yes & Yes & Yes \\
\hline Age FE & Yes & Yes & Yes & Yes & Yes & Yes & Yes & Yes & Yes \\
\hline Gender FE & Yes & Yes & Yes & Yes & Yes & Yes & Yes & Yes & Yes \\
\hline Marital Status FE & Yes & Yes & Yes & Yes & Yes & Yes & Yes & Yes & Yes \\
\hline Adjusted- $R^{2}$ & 0.18 & 0.18 & 0.18 & 0.14 & 0.14 & 0.14 & 0.18 & 0.18 & 0.18 \\
\hline$R^{2}$ & 0.30 & 0.30 & 0.30 & 0.27 & 0.27 & 0.27 & 0.30 & 0.30 & 0.30 \\
\hline Observations & 91613 & 91613 & 91613 & 91613 & 91613 & 91613 & 91613 & 91613 & 91613 \\
\hline
\end{tabular}

Notes: Heteroskedasticity robust standard error estimates three-way clustered by state and country of origin of both parents are reported in parentheses; *** denotes statistical significance at the $1 \%$ level, ** at the $5 \%$ level, and * at the $10 \%$ level, all for two-sided hypothesis tests. 
Table B.4: Pre-1500CE Crop Return, Periphrastic Future Tense, and College Education of Second Generation Migrants

Effect of Parents Origin

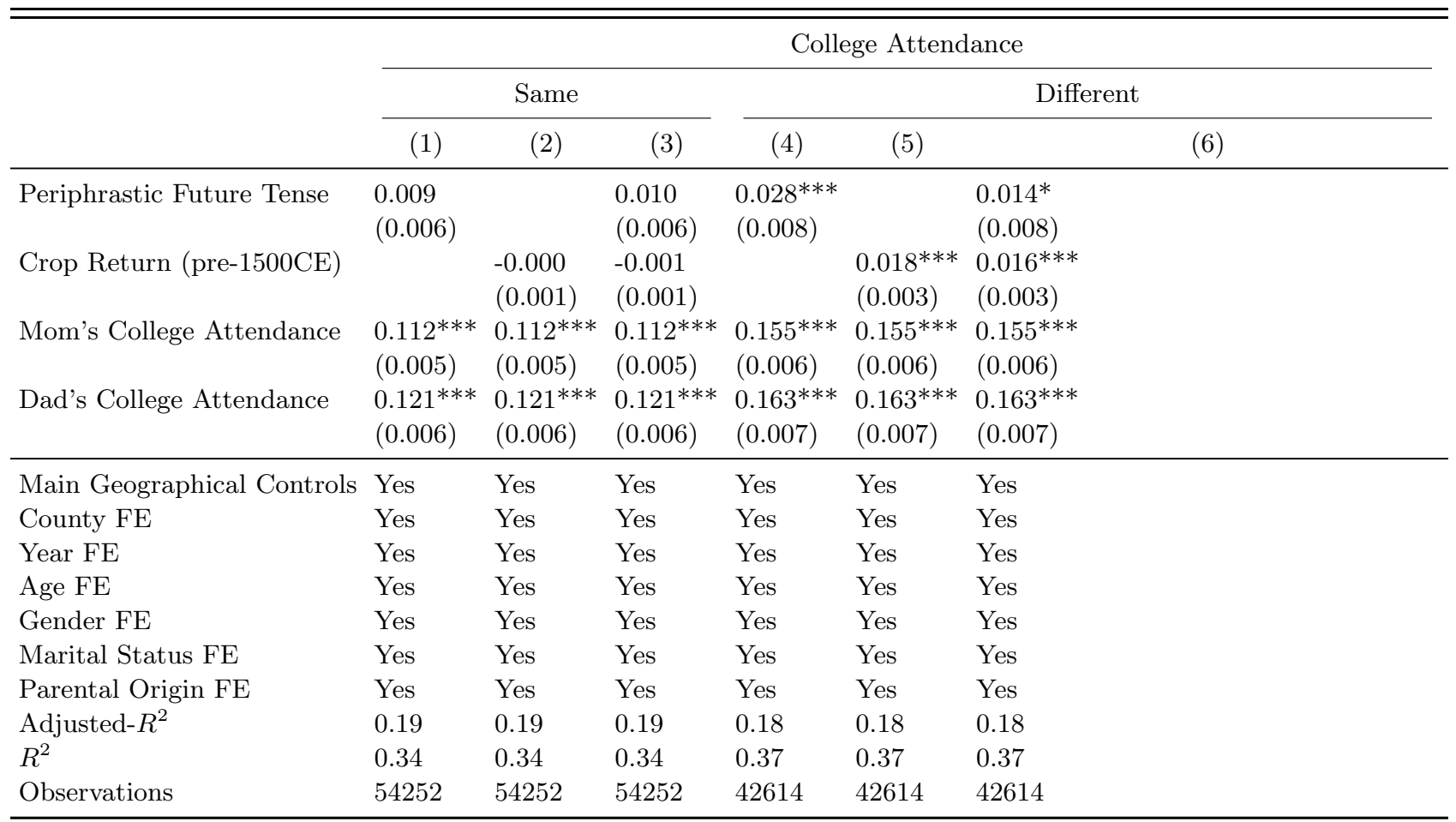

Notes: Heteroskedasticity robust standard error estimates three-way clustered by state and country of origin of both parents are reported in parentheses; *** denotes statistical significance at the $1 \%$ level, ** at the $5 \%$ level, and * at the $10 \%$ level, all for two-sided hypothesis tests.

Table B.5: Pre-1500CE Crop Return, Periphrastic Future Tense, and College Education of Second Generation Migrants

\begin{tabular}{llllllll}
\hline \hline & \multicolumn{6}{c}{ Educational Level Higher than High School } \\
\cline { 2 - 8 } & \multicolumn{1}{c}{$(1)$} & \multicolumn{2}{c}{$(2)$} & $(3)$ & $(4)$ & $(5)$ & $(6)$ \\
\hline Periphrastic Future Tense & $0.218^{* * *}$ & $0.225^{* * *}$ & $0.221^{* * *}$ & $0.056^{* * *}$ & & $0.053^{* * *}$ \\
& $(0.013)$ & $(0.008)$ & $(0.007)$ & $(0.012)$ & & $(0.012)$ \\
Crop Return (pre-1500CE) & & & & & $0.008^{* * *}$ & 0.003 \\
& & & & & $(0.003)$ & $(0.003)$ \\
\hline Main Geographical Controls & Yes & Yes & Yes & Yes & Yes & Yes \\
State FE & Yes & Yes & Yes & Yes & Yes & Yes \\
Year FE & Yes & Yes & Yes & Yes & Yes & Yes \\
Age FE & No & Yes & Yes & Yes & Yes & Yes \\
Gender FE & No & Yes & Yes & Yes & Yes & Yes & \\
Marital Status FE & No & No & Yes & Yes & Yes & Yes \\
Parental Origin FE & No & No & No & Yes & Yes & Yes \\
Adjusted- $R^{2}$ & 0.05 & 0.12 & 0.20 & 0.49 & 0.49 & 0.49 \\
$R^{2}$ & 0.05 & 0.12 & 0.20 & 0.49 & 0.49 & 0.49 \\
Observations & 18845303 & 18845303 & 18845303 & 18845303 & 18845303 & 18845303 \\
\hline
\end{tabular}

Notes: Heteroskedasticity robust standard error estimates clustered at the level of the included fixed-effects are reported in parentheses; $* * *$ denotes statistical significance at the $1 \%$ level, ** at the $5 \%$ level, and * at the $10 \%$ level, all for two-sided hypothesis tests. 
Table B.6: Pre-1500CE Crop Return, Periphrastic Future Tense, and College Education of Second Generation Migrants

Accounting for Parental Education and English Levels

\begin{tabular}{|c|c|c|c|c|c|c|c|c|c|}
\hline & \multicolumn{9}{|c|}{ Educational Level Higher than High School } \\
\hline & \multicolumn{3}{|c|}{ Parental Education } & \multicolumn{3}{|c|}{ Parental English } & \multicolumn{3}{|c|}{ Both } \\
\hline & $(1)$ & $(2)$ & $(3)$ & $(4)$ & $(5)$ & (6) & $(7)$ & $(8)$ & $(9)$ \\
\hline Periphrastic Future Tense & $\begin{array}{l}0.056^{* * *} \\
(0.008)\end{array}$ & & $\begin{array}{l}0.052^{* * *} \\
(0.009)\end{array}$ & $\begin{array}{l}0.041^{* * *} \\
(0.010)\end{array}$ & & $\begin{array}{l}0.042^{* * *} \\
(0.011)\end{array}$ & $\begin{array}{l}0.037^{* * *} \\
(0.010)\end{array}$ & & $\begin{array}{l}0.038^{* * *} \\
(0.011)\end{array}$ \\
\hline Crop Return (pre-1500CE) & & $\begin{array}{l}0.010 * * * \\
(0.002)\end{array}$ & $\begin{array}{l}0.004^{*} \\
(0.002)\end{array}$ & & $\begin{array}{l}0.002 \\
(0.003)\end{array}$ & $\begin{array}{l}-0.002 \\
(0.003)\end{array}$ & & $\begin{array}{l}0.003 \\
(0.003)\end{array}$ & $\begin{array}{l}-0.000 \\
(0.003)\end{array}$ \\
\hline Mom's Education Level (HS+) & $\begin{array}{l}0.137^{* * *} \\
(0.004)\end{array}$ & $\begin{array}{l}0.137^{* * *} \\
(0.004)\end{array}$ & $\begin{array}{l}0.137^{* * *} \\
(0.004)\end{array}$ & & & & $\begin{array}{l}0.138^{* * *} \\
(0.005)\end{array}$ & $\begin{array}{l}0.138^{* * *} \\
(0.005)\end{array}$ & $\begin{array}{l}0.138^{* * *} \\
(0.005)\end{array}$ \\
\hline Dad's Education Level (HS+) & $\begin{array}{l}0.069^{* * *} \\
(0.004)\end{array}$ & $\begin{array}{l}0.069^{* * *} \\
(0.004)\end{array}$ & $\begin{array}{l}0.069^{* * *} \\
(0.004)\end{array}$ & & & & $\begin{array}{l}0.147^{* * *} \\
(0.005)\end{array}$ & $\begin{array}{l}0.147^{* * *} \\
(0.005)\end{array}$ & $\begin{array}{l}0.147^{* * *} \\
(0.005)\end{array}$ \\
\hline Mom's English Level & & & & $\begin{array}{l}0.012^{* * * *} \\
(0.002)\end{array}$ & $\begin{array}{l}0.012^{* * *} \\
(0.002)\end{array}$ & $\begin{array}{l}0.012^{* * *} \\
(0.002)\end{array}$ & $\begin{array}{l}0.013^{* * *} \\
(0.002)\end{array}$ & $\begin{array}{l}0.013^{* * *} \\
(0.002)\end{array}$ & $\begin{array}{l}0.013^{* * *} \\
(0.002)\end{array}$ \\
\hline Dad's English Level & & & & $\begin{array}{l}-0.002 \\
(0.002)\end{array}$ & $\begin{array}{l}-0.002 \\
(0.002)\end{array}$ & $\begin{array}{l}-0.002 \\
(0.002)\end{array}$ & $\begin{array}{l}0.003^{*} \\
(0.002)\end{array}$ & $\begin{array}{l}0.003^{*} \\
(0.002)\end{array}$ & $\begin{array}{l}0.003^{*} \\
(0.002)\end{array}$ \\
\hline Main Geographical Controls & Yes & Yes & Yes & Yes & Yes & Yes & Yes & Yes & Yes \\
\hline Origin FE for Both Parents & Yes & Yes & Yes & Yes & Yes & Yes & Yes & Yes & Yes \\
\hline State FE & Yes & Yes & Yes & Yes & Yes & Yes & Yes & Yes & Yes \\
\hline Year FE & Yes & Yes & Yes & Yes & Yes & Yes & Yes & Yes & Yes \\
\hline Age FE & Yes & Yes & Yes & Yes & Yes & Yes & Yes & Yes & Yes \\
\hline Gender FE & Yes & Yes & Yes & Yes & Yes & Yes & Yes & Yes & Yes \\
\hline Marital Status FE & Yes & Yes & Yes & Yes & Yes & Yes & Yes & Yes & Yes \\
\hline Parental Origin FE & Yes & Yes & Yes & Yes & Yes & Yes & Yes & Yes & Yes \\
\hline Adjusted- $R^{2}$ & 0.25 & 0.25 & 0.25 & 0.26 & 0.26 & 0.26 & 0.29 & 0.29 & 0.29 \\
\hline$R^{2}$ & 0.25 & 0.25 & 0.25 & 0.26 & 0.26 & 0.26 & 0.29 & 0.29 & 0.29 \\
\hline Observations & 18845303 & 18845303 & 18845303 & 11187136 & 11187136 & 11187136 & 11187136 & 11187136 & 11187136 \\
\hline
\end{tabular}


Table B.7: Pre-1500CE Crop Return, Periphrastic Future Tense, and College Education One-and-a-Half Generation Migrants (Who Arrived at Age $\leq 5$ )

\begin{tabular}{llllllll}
\hline \hline & \multicolumn{6}{c}{ Educational Level Higher than High School } \\
\cline { 2 - 7 } & \multicolumn{1}{c}{$(1)$} & \multicolumn{2}{c}{$(2)$} & $(3)$ & $(4)$ & $(5)$ & $(6)$ \\
\hline Periphrastic Future Tense & $0.220^{* * *}$ & $0.223^{* * *}$ & $0.219^{* * *}$ & $0.067^{* * *}$ & $0.067^{* * *}$ & \\
& $(0.011)$ & $(0.006)$ & $(0.006)$ & $(0.007)$ & & $(0.007)$ & \\
Crop Return (pre-1500CE) & & & & & $0.007^{* * *}$ & -0.000 \\
& & & & & $(0.002)$ & $(0.002)$ & \\
& & & & & Yes & Yes & Yes \\
Main Geographical Controls & Yes & Yes & Yes & Yes & Yes \\
State FE & Yes & Yes & Yes & Yes & Yes & Yes \\
Year FE & Yes & Yes & Yes & Yes & Yes & Yes \\
Age FE & No & Yes & Yes & Yes & Yes & Yes \\
Gender FE & No & Yes & Yes & Yes & Yes & Yes \\
Marital Status FE & No & No & Yes & Yes & Yes & Yes \\
Parental Origin FE & No & No & No & Yes & Yes & 0.55 \\
Adjusted- $R^{2}$ & 0.06 & 0.12 & 0.20 & 0.55 & 0.55 & 0.55 \\
$R^{2}$ & 0.06 & 0.12 & 0.20 & 0.55 & 0.55 & 0.55 \\
Observations & 42457006 & 42457006 & 42457006 & 42457006 & 42457006 & 42457006 & \\
\hline
\end{tabular}

Notes: Heteroskedasticity robust standard error estimates clustered at the level of the included fixed-effects are reported in parentheses; $* * *$ denotes statistical significance at the $1 \%$ level, $* *$ at the $5 \%$ level, and * at the $10 \%$ level, all for two-sided hypothesis tests. 


\section{B.2 Comparing Migrants Samples}

Table B.8: Means across Generational Samples (Census vs. CPS)

\begin{tabular}{|c|c|c|c|c|c|c|c|c|}
\hline & \multicolumn{8}{|c|}{ Means } \\
\hline & \multicolumn{2}{|c|}{1.5 Generation } & \multicolumn{4}{|c|}{ 2nd Generation } & \multicolumn{2}{|c|}{$2+$ Generations } \\
\hline & Census & CPS & Census & $\begin{array}{l}\text { CPS } \\
\text { (living } \\
\text { with } \\
\text { Parents) } \\
\end{array}$ & $\begin{array}{l}\text { CPS } \\
\text { (not liv- } \\
\text { ing with } \\
\text { Parents) }\end{array}$ & $\begin{array}{l}\text { CPS } \\
\text { (All) }\end{array}$ & Census & $\begin{array}{l}\text { CPS }(3+ \\
\text { Genera- } \\
\text { tion) }\end{array}$ \\
\hline & (1) & $(2)$ & (3) & $(4)$ & $(5)$ & (6) & (7) & (8) \\
\hline Education Level (HS+) & $\begin{array}{l}0.596^{* * *} \\
(0.001)\end{array}$ & $\begin{array}{l}0.648^{* * *} \\
(0.001)\end{array}$ & $\begin{array}{l}0.552^{* * * *} \\
(0.001)\end{array}$ & $\begin{array}{l}0.600^{* * *} \\
(0.002)\end{array}$ & $\begin{array}{l}0.568^{* * *} \\
(0.000)\end{array}$ & $\begin{array}{l}0.571^{* * *} \\
(0.000)\end{array}$ & $\begin{array}{l}0.535^{* * *} \\
(0.000)\end{array}$ & $\begin{array}{l}0.572^{* * *} \\
(0.000)\end{array}$ \\
\hline Age & $\begin{array}{l}43.742^{* * *} \\
(0.022)\end{array}$ & $\begin{array}{l}38.625^{* * *} \\
(0.024)\end{array}$ & $\begin{array}{l}33.913^{* * *} \\
(0.022)\end{array}$ & $\begin{array}{l}34.092^{* * *} \\
(0.032)\end{array}$ & $\begin{array}{l}55.963^{* * *} \\
(0.017)\end{array}$ & $\begin{array}{l}54.376^{* * *} \\
(0.017)\end{array}$ & $\begin{array}{l}51.685^{* * *} \\
(0.004)\end{array}$ & $\begin{array}{l}50.133^{* * *} \\
(0.004)\end{array}$ \\
\hline Gender & $\begin{array}{l}1.518^{* * *} \\
(0.001)\end{array}$ & $\begin{array}{l}1.518^{* * *} \\
(0.001)\end{array}$ & $\begin{array}{l}1.457^{* * *} \\
(0.001)\end{array}$ & $\begin{array}{l}1.462^{* * *} \\
(0.002)\end{array}$ & $\begin{array}{l}1.537^{* * *} \\
(0.000)\end{array}$ & $\begin{array}{l}1.531^{* * *} \\
(0.000)\end{array}$ & $\begin{array}{l}1.526^{* * *} \\
(0.000)\end{array}$ & $\begin{array}{l}1.527^{* * *} \\
(0.000)\end{array}$ \\
\hline Marital Status & $\begin{array}{l}2.702^{* * *} \\
(0.003)\end{array}$ & $\begin{array}{l}2.737^{* * *} \\
(0.005)\end{array}$ & $\begin{array}{l}4.933^{* * *} \\
(0.004)\end{array}$ & $\begin{array}{l}5.099 * * * \\
(0.005)\end{array}$ & $\begin{array}{l}2.597^{* * *} * \\
(0.002)\end{array}$ & $\begin{array}{l}2.779^{* * *} \\
(0.002)\end{array}$ & $\begin{array}{l}2.524^{* * *} \\
(0.000)\end{array}$ & $\begin{array}{l}2.489 * * * \\
(0.001)\end{array}$ \\
\hline Observations & 429372 & 174094 & 181099 & 94331 & 1205633 & 1299964 & 20596324 & 14180541 \\
\hline
\end{tabular}

Notes: Standard error estimates are reported in parentheses; *** denotes statistical significance at the $1 \%$ level, ** at the $5 \%$ level, and * at the $10 \%$ level, all for two-sided hypothesis tests.

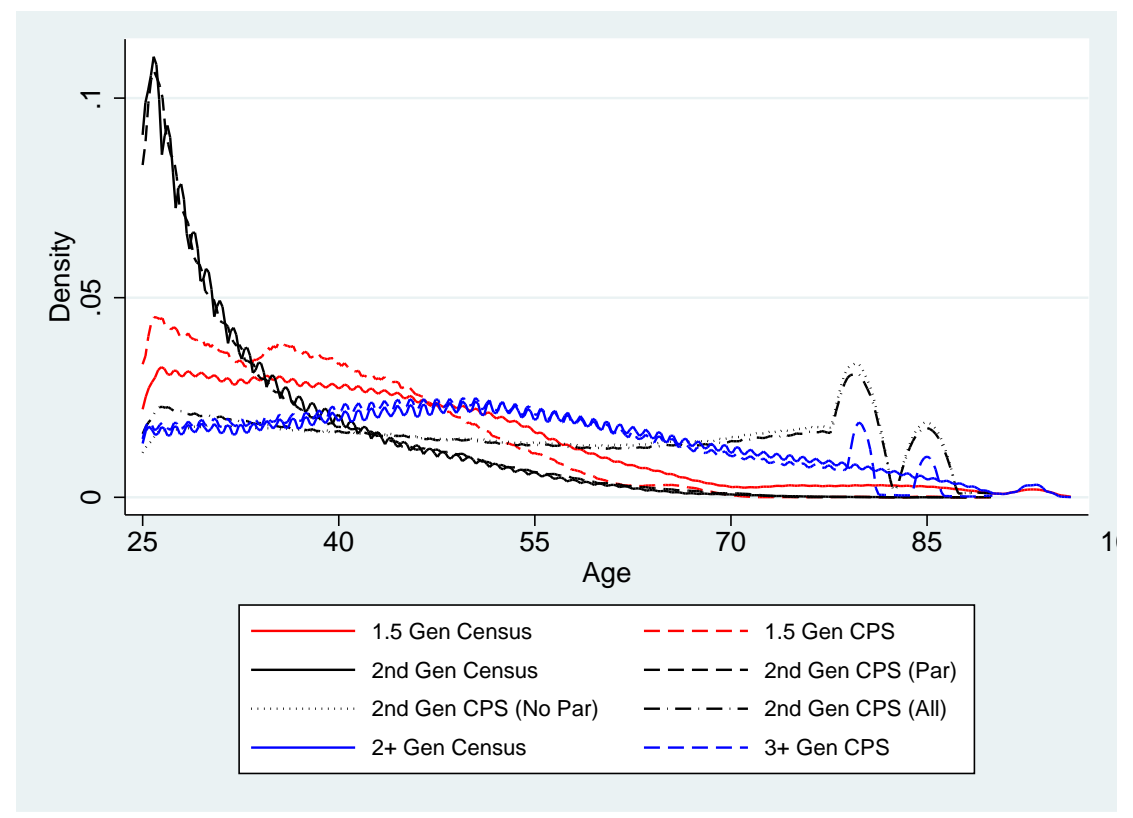

Figure B.1: Age Density in the Census and CPS 
Table B.9: Means across Generational Samples (Census vs. CPS)

\begin{tabular}{|c|c|c|c|c|c|c|c|c|}
\hline & \multicolumn{8}{|c|}{ Means } \\
\hline & \multicolumn{2}{|c|}{1.5 Generation } & \multicolumn{4}{|c|}{ 2nd Generation } & \multicolumn{2}{|c|}{$2+$ Generations } \\
\hline & Census & CPS & Census & $\begin{array}{l}\text { CPS } \\
\text { (living } \\
\text { with } \\
\text { Parents) }\end{array}$ & $\begin{array}{l}\text { CPS } \\
\text { (not liv- } \\
\text { ing with } \\
\text { Parents) }\end{array}$ & $\begin{array}{l}\text { CPS } \\
\text { (All) }\end{array}$ & Census & $\begin{array}{l}\text { CPS }(3+ \\
\text { Genera- } \\
\text { tion) }\end{array}$ \\
\hline & (1) & $(2)$ & (3) & (4) & (5) & (6) & (7) & (8) \\
\hline Education Level (HS+) & $\begin{array}{l}0.590^{* * *} \\
(0.000)\end{array}$ & $\begin{array}{l}0.638^{* * *} \\
(0.000)\end{array}$ & $\begin{array}{l}0.545^{* * *} \\
(0.000)\end{array}$ & $\begin{array}{l}0.603^{* * *} \\
(0.000)\end{array}$ & $\begin{array}{l}0.581^{* * *} \\
(0.000)\end{array}$ & $\begin{array}{l}0.583^{* * *} \\
(0.000)\end{array}$ & $\begin{array}{l}0.542^{* * *} \\
(0.000)\end{array}$ & $\begin{array}{l}0.568^{* * * *} \\
(0.000)\end{array}$ \\
\hline Age & $\begin{array}{l}42.489^{* * *} \\
(0.002)\end{array}$ & $\begin{array}{l}38.163^{* * *} \\
(0.000)\end{array}$ & $\begin{array}{l}33.347^{* * *} \\
(0.002)\end{array}$ & $\begin{array}{l}33.505^{* * *} \\
(0.001)\end{array}$ & $\begin{array}{l}54.517^{* * *} \\
(0.000)\end{array}$ & $\begin{array}{l}52.666^{* * *} \\
(0.000)\end{array}$ & $\begin{array}{l}50.258^{* * *} \\
(0.000)\end{array}$ & $\begin{array}{l}49.930^{* * *} \\
(0.000)\end{array}$ \\
\hline Gender & $\begin{array}{l}1.510^{* * *} \\
(0.000)\end{array}$ & $\begin{array}{l}1.503^{* * *} \\
(0.000)\end{array}$ & $\begin{array}{l}1.445^{* * *} \\
(0.000)\end{array}$ & $\begin{array}{l}1.437^{* * *} \\
(0.000)\end{array}$ & $\begin{array}{l}1.530^{* * *} \\
(0.000)\end{array}$ & $\begin{array}{l}1.521^{* * * *} \\
(0.000)\end{array}$ & $\begin{array}{l}1.522^{* * *} \\
(0.000)\end{array}$ & $\begin{array}{l}1.524^{* * *} \\
(0.000)\end{array}$ \\
\hline Marital Status & $\begin{array}{l}2.855^{* * *} \\
(0.000)\end{array}$ & $\begin{array}{l}2.810^{* * *} \\
(0.000)\end{array}$ & $\begin{array}{l}5.000 * * * \\
(0.000)\end{array}$ & $\begin{array}{l}5.143^{* * *} \\
(0.000)\end{array}$ & $\begin{array}{l}2.624^{* * *} \\
(0.000)\end{array}$ & $\begin{array}{l}2.846^{* * *} \\
(0.000)\end{array}$ & $\begin{array}{l}2.679^{* * *} \\
(0.000)\end{array}$ & $\begin{array}{l}2.547^{* * * *} \\
(0.000)\end{array}$ \\
\hline Observations & 43181154 & 403711034 & 20841131 & 245898566 & 2544423483 & 2790322049 & 1831557413 & 28887227869 \\
\hline
\end{tabular}




\section{B.3 Future Tense and Education in the WVS}

Table B.10: Pre1500 Crop Return, Periphrastic Future Tense, and Education - World Values Survey

\begin{tabular}{|c|c|c|c|c|c|c|c|c|c|}
\hline & \multicolumn{9}{|c|}{ Education Level } \\
\hline & \multicolumn{3}{|c|}{ Basic Controls } & \multicolumn{3}{|c|}{ Income } & \multicolumn{3}{|c|}{ Religion } \\
\hline & (1) & $(2)$ & $(3)$ & $(4)$ & $(5)$ & (6) & $(7)$ & (8) & $(9)$ \\
\hline Crop Return (pre-1500CE) & $\begin{array}{l}0.18^{* * *} \\
(0.04)\end{array}$ & & $\begin{array}{l}0.23^{* * *} \\
(0.04)\end{array}$ & $\begin{array}{l}0.18^{* * *} \\
(0.04)\end{array}$ & & $\begin{array}{l}0.23^{* * *} \\
(0.04)\end{array}$ & $\begin{array}{l}0.25^{* * *} \\
(0.04)\end{array}$ & & $\begin{array}{l}0.28^{* * *} \\
(0.04)\end{array}$ \\
\hline Periphrastic Future Tense & & $\begin{array}{l}0.43^{* * *} \\
(0.05)\end{array}$ & $\begin{array}{l}0.47 * * * \\
(0.05)\end{array}$ & & $\begin{array}{l}0.40 * * * \\
(0.05)\end{array}$ & $\begin{array}{l}0.44^{* * *} \\
(0.05)\end{array}$ & & $\begin{array}{l}0.25 * * * \\
(0.05)\end{array}$ & $\begin{array}{l}0.30 * * * \\
(0.05)\end{array}$ \\
\hline Income FE & No & No & No & No & No & No & Yes & Yes & Yes \\
\hline Religion FE & No & No & No & Yes & Yes & Yes & Yes & Yes & Yes \\
\hline Main Geographical Controls & Yes & Yes & Yes & Yes & Yes & Yes & Yes & Yes & Yes \\
\hline Country FE & Yes & Yes & Yes & Yes & Yes & Yes & Yes & Yes & Yes \\
\hline Wave FE & Yes & Yes & Yes & Yes & Yes & Yes & Yes & Yes & Yes \\
\hline Gender FE & Yes & Yes & Yes & Yes & Yes & Yes & Yes & Yes & Yes \\
\hline Age FE & Yes & Yes & Yes & Yes & Yes & Yes & Yes & Yes & Yes \\
\hline Adjusted- $R^{2}$ & -0.01 & -0.01 & -0.01 & -0.01 & -0.01 & -0.01 & 0.09 & 0.09 & 0.09 \\
\hline Observations & 108213 & 108213 & 108213 & 108213 & 108213 & 108213 & 108213 & 108213 & 108213 \\
\hline
\end{tabular}




\section{Origins and Effects of Other Language Structures}

Table C.1: Geographic Origins of Sex-Based Grammatical Genders and Plow Usage

\begin{tabular}{|c|c|c|c|c|c|c|}
\hline & \multicolumn{6}{|c|}{ Results (Probit) } \\
\hline & \multirow{2}{*}{\multicolumn{2}{|c|}{$\frac{\text { Reduced Form }}{\text { Gender }}$}} & \multicolumn{4}{|c|}{ Mechanism } \\
\hline & & & \multicolumn{2}{|c|}{ Plow Usage } & \multicolumn{2}{|c|}{ Gender } \\
\hline & (1) & $(2)$ & $(3)$ & $(4)$ & $(5)$ & (6) \\
\hline Average Caloric Yield (Plow Negative Crops, pre-1500) & $\begin{array}{l}-0.12^{* *} \\
(0.05)\end{array}$ & $\begin{array}{l}-0.19^{* * *} \\
(0.07)\end{array}$ & $\begin{array}{l}-0.19^{* * *} \\
(0.02)\end{array}$ & $\begin{array}{l}0.01 \\
(0.02)\end{array}$ & & \\
\hline Average Caloric Yield (All Crops, pre-1500) & $\begin{array}{l}0.14^{* * *} \\
(0.05)\end{array}$ & $\begin{array}{l}0.21^{* * *} \\
(0.06)\end{array}$ & $\begin{array}{l}0.17^{* * *} \\
(0.02)\end{array}$ & $\begin{array}{l}0.08^{* * *} \\
(0.02)\end{array}$ & & \\
\hline Plow Usage & & & & & $\begin{array}{l}0.32^{* * *} \\
(0.07)\end{array}$ & $\begin{array}{l}0.23^{* *} \\
(0.10)\end{array}$ \\
\hline All Geographic Controls & No & Yes & No & Yes & No & Yes \\
\hline Continental FE & No & Yes & No & Yes & No & Yes \\
\hline Pseudo- $R^{2}$ & 0.03 & 0.25 & 0.23 & 0.52 & 0.11 & 0.37 \\
\hline Observations & 217 & 217 & 1178 & 824 & 114 & 101 \\
\hline
\end{tabular}

Notes: This table establishes the positive statistically and economically significant effect of the geographical determinants of and actual plow usage on the existence of sex-based grammatical gender in a language. The first two columns provide the results of the reduced form, and columns (3)-(6) provide evidence on the mechanism. The table shows the average marginal effects of a Probit regression. Heteroskedasticity robust standard error estimates are reported in parentheses; *** denotes statistical significance at the $1 \%$ level, $* *$ at the $5 \%$ level, and * at the $10 \%$ level, all for two-sided hypothesis tests. 


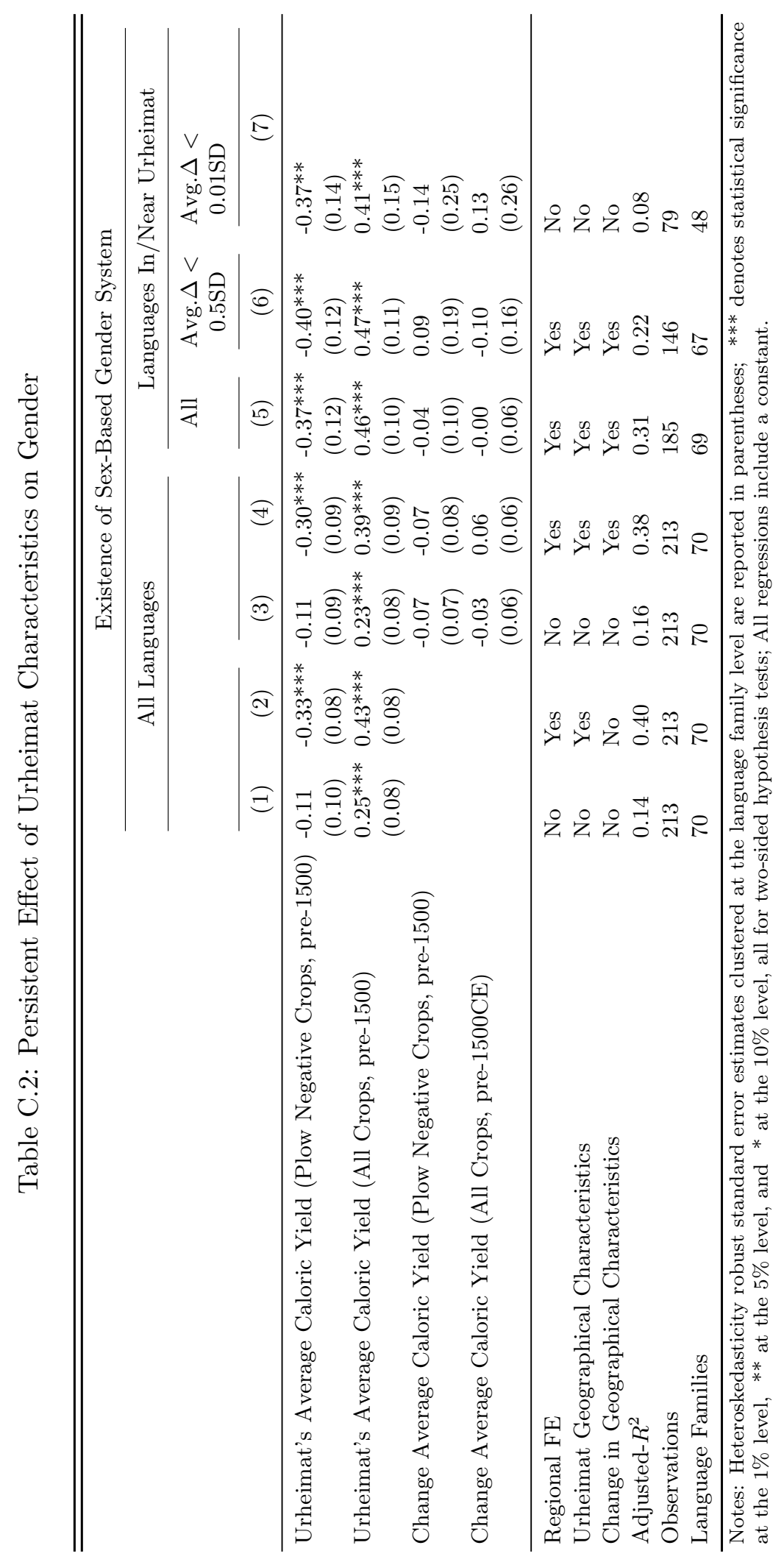


Table C.3: Persistent Effect of Urheimat Characteristics on Politeness

\begin{tabular}{|c|c|c|c|c|c|c|c|}
\hline & \multicolumn{7}{|c|}{ Existence of Politeness Distinctions } \\
\hline & \multicolumn{4}{|c|}{ All Languages } & \multicolumn{3}{|c|}{ Languages In/Near Urheimat } \\
\hline & & & & & All & $\begin{array}{c}\text { Avg. } \Delta< \\
0.5 \mathrm{SD}\end{array}$ & $\begin{array}{c}\text { Avg. } \Delta< \\
0.01 \mathrm{SD}\end{array}$ \\
\hline & $(1)$ & $(2)$ & $(3)$ & $(4)$ & $(5)$ & $(6)$ & $(7)$ \\
\hline Ecological Diversity & $\begin{array}{l}0.16^{* *} \\
(0.08)\end{array}$ & $\begin{array}{l}-0.07 \\
(0.08)\end{array}$ & $\begin{array}{l}0.24^{* * *} \\
(0.07)\end{array}$ & $\begin{array}{l}0.00 \\
(0.08)\end{array}$ & $\begin{array}{l}-0.01 \\
(0.08)\end{array}$ & $\begin{array}{l}0.01 \\
(0.09)\end{array}$ & $\begin{array}{l}0.11 \\
(0.18)\end{array}$ \\
\hline Average Caloric Yield (All Crops, pre-1500) & $\begin{array}{l}0.08^{*} \\
(0.04)\end{array}$ & $\begin{array}{l}0.11^{*} \\
(0.06)\end{array}$ & $\begin{array}{l}0.09 * * \\
(0.04)\end{array}$ & $\begin{array}{l}0.08 \\
(0.05)\end{array}$ & $\begin{array}{l}0.04 \\
(0.05)\end{array}$ & $\begin{array}{l}0.01 \\
(0.05)\end{array}$ & $\begin{array}{l}0.07 \\
(0.07)\end{array}$ \\
\hline Change Ecological Diversity $(\Delta E D)$ & & & $\begin{array}{l}0.10^{* * *} \\
(0.04)\end{array}$ & $\begin{array}{l}0.09 * * \\
(0.04)\end{array}$ & $\begin{array}{l}0.09^{*} \\
(0.04)\end{array}$ & $\begin{array}{l}-0.01 \\
(0.08)\end{array}$ & $\begin{array}{l}-0.00 \\
(0.05)\end{array}$ \\
\hline Change Average Caloric Yield (All Crops, pre-1500) & & & $\begin{array}{l}0.08 \\
(0.05)\end{array}$ & $\begin{array}{l}0.08^{* *} \\
(0.04)\end{array}$ & $\begin{array}{l}0.12^{* * *} \\
(0.04)\end{array}$ & $\begin{array}{l}-0.00 \\
(0.10)\end{array}$ & $\begin{array}{l}-0.01 \\
(0.07)\end{array}$ \\
\hline Regional FE & No & Yes & No & Yes & Yes & Yes & No \\
\hline Urheimat Geographical Characteristics & No & Yes & No & Yes & Yes & Yes & No \\
\hline Change in Geographical Characteristics & No & No & No & Yes & Yes & Yes & No \\
\hline Adjusted- $R^{2}$ & 0.15 & 0.32 & 0.19 & 0.40 & 0.37 & 0.40 & -0.14 \\
\hline Observations & 196 & 196 & 196 & 196 & 169 & 109 & 21 \\
\hline Language Families & 66 & 66 & 66 & 66 & 64 & 54 & 20 \\
\hline
\end{tabular}

Notes: Heteroskedasticity robust standard error estimates clustered at the language family level are reported in parentheses; *** denotes statistical significance at the $1 \%$ level, ** at the $5 \%$ level, and * at the $10 \%$ level, all for two-sided hypothesis tests; All regressions include a constant. 


\section{Variable Definitions, Sources and Summary Statistics}

Table D.1: Summary Statistics of the Existence of Periphrastic Future Tense by Region

\begin{tabular}{lccc}
\hline \hline \multicolumn{1}{c}{ Region } & Observations & Mean & Std. Dev. \\
\hline Sub-Saharan Africa & 66 & 0.53 & 0.503 \\
Middle East and North Africa & 8 & 0.5 & 0.53 \\
Europe and Central Asia & 56 & 0.48 & 0.50 \\
South Asia & 21 & 0.19 & 0.40 \\
East Asia and Pacific & 71 & 0.55 & 0.50 \\
North America & 22 & 0.41 & 0.50 \\
Latin America & 31 & 0.55 & 0.50 \\
\hline Total & 275 & 0.49 & 0.50 \\
\hline
\end{tabular}

Table D.2: Summary Statistics of the Existence of Sex-Based Grammatical Gender Systems by Region

\begin{tabular}{lccc}
\hline \hline \multicolumn{1}{c}{ Region } & Observations & Mean & Std. Dev. \\
\hline Sub-Saharan Africa & 27 & 0.63 & 0.49 \\
Middle East and North Africa & 7 & 0.71 & 0.49 \\
Europe and Central Asia & 40 & 0.48 & 0.51 \\
South Asia & 16 & 0.63 & 0.50 \\
East Asia and Pacific & 70 & 0.27 & 0.45 \\
North America & 25 & 0.08 & 0.28 \\
Latin America & 32 & 0.28 & 0.46 \\
\hline Total & 227 & 0.37 & 0.48 \\
\hline
\end{tabular}

Table D.3: Summary Statistics of the Existence of Politeness Distinctions by Region

\begin{tabular}{lccc}
\hline \hline \multicolumn{1}{c}{ Region } & Observations & Mean & Std. Dev. \\
\hline Sub-Saharan Africa & 36 & 0.14 & 0.35 \\
Middle East and North Africa & 4 & 0.25 & 0.50 \\
Europe and Central Asia & 34 & 0.71 & 0.46 \\
South Asia & 19 & 0.63 & 0.50 \\
East Asia and Pacific & 59 & 0.32 & 0.47 \\
North America & 18 & 0.00 & 0.00 \\
Latin America & 28 & 0.18 & 0.39 \\
\hline Total & 207 & 0.34 & 0.48 \\
\hline
\end{tabular}


Table D.4: Summary statistics

\begin{tabular}{lccccc}
\hline \multicolumn{1}{c}{ Variable } & Mean & Std. Dev. & Min. & Max. & N \\
\hline Absolute Latitude & 0.096 & 1.025 & -1.302 & 2.613 & 275 \\
Elevation & 0.027 & 1.026 & -0.92 & 4.827 & 275 \\
Ruggedness & -0.014 & 0.979 & -0.877 & 6.162 & 275 \\
Coast Length & 0.024 & 1.154 & -0.302 & 11.692 & 275 \\
Precipitation & -0.078 & 0.928 & -1.3 & 4.4 & 275 \\
Precipitation (std) & -0.02 & 0.911 & -0.667 & 8.314 & 275 \\
Precipitation Volatility & -0.064 & 0.926 & -1.531 & 4.665 & 275 \\
Precipitation Spatial Correlation & 0.064 & 0.939 & -2.133 & 0.810 & 275 \\
Temperature (Daily Mean) & -0.054 & 0.977 & -2.996 & 1.176 & 275 \\
Temperature (Daily Mean) (std) & -0.017 & 0.929 & -0.877 & 4.876 & 275 \\
Temperature Volatility & 0.079 & 0.991 & -1.641 & 3.504 & 275 \\
Temperature Spatial Correlation & 0.068 & 0.939 & -2.161 & 0.683 & 275 \\
\hline
\end{tabular}

Table D.5: Summary statistics

\begin{tabular}{cccccc}
\hline \hline Variable & Mean & Std. Dev. & Min. & Max. & N \\
\hline Intensity of Agriculture & 8.890 & 3.061 & 2 & 12 & 264 \\
\hline
\end{tabular}

